FRANCISCO PAULO BASILE AVESANI

\title{
Fluência confinada e acelerada em geossintéticos
}

Dissertação apresentada à Escola de Engenharia de São Carlos da Universidade de São Paulo, como parte dos requisitos para obtenção do Título de Mestre em Ciências, Programa de Pós-Graduação em Geotecnia.

Orientador: Prof. Dr. Orencio Monje Vilar

\section{Versão Corrigida}

São Carlos

2013 
AUTORIZO A REPRODUÇÃO TOTAL OU PARCIAL DESTE TRABALHO, POR QUALQUER MEIO CONVENCIONAL OU ELETRÔNICO, PARA FINS DE ESTUDO E PESQUISA, DESDE QUE CITADA A FONTE.

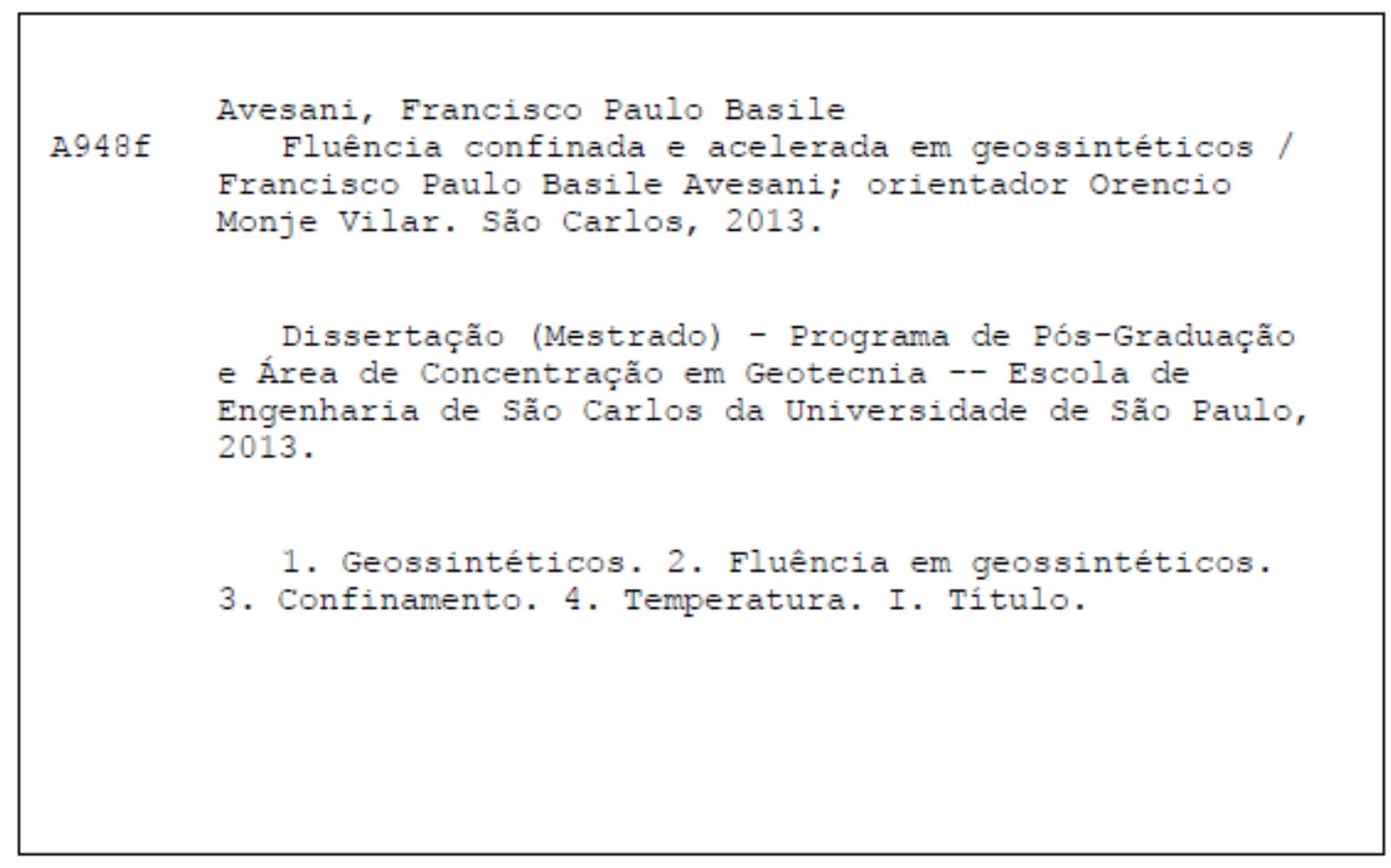




\section{FOLHA DE JULGAMENTO}

Candidato: Engenheiro FRANCISCO PAULO BASILE AVESANI.

Título da dissertação: "Fluência confinada e acelerada em geossintéticos.".

Data da defesa: 01/02/2013

Comissão Julgadora:

Prof. Titular Orencio Monje Vilar (Orientador)

(Escola de Engenharia de São Carlos/EESC)

Prof. Dr. Sidnei Helder Cardoso Teixeira

(Universidade Federal do Paraná/UFPR)

Prof. Dr. Marcos Antonio Garcia Ferreira

(Universidade Federal de São Carlos/UFSCar)

Coordenador do Programa de Pós-Graduação em Geotecnia:

Prof. Titular Osni José Pejon

Presidente da Comissão de Pós-Graduação:

Prof. Titular Denis Vinicius Coury
Resultado:

APROVADO

APROYADO

APRONADO 

A Adriana, por todo o seu apoio e amor. Aos meus pais, Luiz e Valéria. Aos meus irmãos, José Orlando e Pedro. 



\section{AGRADECIMENTOS}

Agradeço a Deus, pela saúde e pelo dom da vida.

A minha esposa Adriana, por acreditar em meu potencial e acompanhar-me em todos os passos de minha vida.

Aos meus pais, Luiz e Valéria, meus primeiros Orientadores e grandes responsáveis por todas as minhas conquistas.

Aos meus irmãos e companheiros, José Orlando, Pedro, Paula, Uilian e Alexandre, pela amizade e pelos momentos vividos juntos.

Ao meu sogro e minha sogra, Adão e Aparecida, pelo apoio e incentivo aos meus estudos.

Aos meus avôs, presentes e aos que já se foram, pelo carinho e amor.

Aos amigos da graduação, Leonardo Carlos, Leonardo Bernini, Leandro e Caio, pela amizade. Aos amigos da pós-graduação, em especial a todos do Laboratório de Geossintéticos: Jorge, Marcus, Clever, Walter, Manuel, Tiago, Marcão, Fernando e Natália.

Ao Prof. Dr. Benedito de Souza Bueno, pela oportunidade a mim concedida.

Ao Prof. Dr. Orencio Monje Vilar, pela orientação, apoio, paciência e tempo concedido.

Ao Prof. Dr. Fagner Alexandre Nunes de França, pelo seu carinho, amizade e por todos os momentos de ajuda.

Aos demais professores e funcionários do Departamento de Geotecnia da EESC/USP, agradeço pelos ensinamentos e apoio.

Ao Conselho Nacional de Desenvolvimento Científico e Tecnológico (CNPq) pelo apoio financeiro dado ao desenvolvimento dessa dissertação.

Às empresas Huesker Ltda. e OBER Geossintéticos pela doação de materiais utilizados nesta pesquisa. 

“O SENHOR é o meu pastor e nada me faltará."

Salmos 23:1 



\section{RESUMO}

AVESANI, F. P. B. Fluência confinada e acelerada em geossintéticos. 2013. 134 f. Dissertação - Escola de Engenharia de São Carlos, Universidade de São Paulo, São Carlos, 2013.

O comportamento em fluência é uma propriedade fundamental dos geossintéticos utilizados em estruturas de solo reforçado. Este parâmetro geralmente é caracterizado por meio de ensaios padronizados, que utilizam corpos de prova em condição não confinada, com temperatura e umidade controlada. Embora este ensaio seja utilizado na prática atual, o mesmo apresenta dois pontos negativos: grande tempo demandado para obtenção de uma resposta significativa quanto a esse comportamento (até 10.000 horas de ensaio) e o fato de não considerar o efeito do confinamento em solo. Para contornar essas deficiências, os ensaios padronizados podem ser realizados em temperaturas elevadas e sob condição de confinamento em solo. Estas abordagens têm sido apresentadas na literatura técnica, a fim de considerar cada um desses aspectos, mas apenas de forma independente. Recentemente, foi desenvolvido um equipamento capaz de conduzir ensaios de fluência confinado e acelerado em geossintéticos, considerando simultaneamente ambas as preocupações abordadas. Deste modo, este trabalho apresenta um conjunto de ensaios de fluência realizados sob diferentes condições com este equipamento. Um geotêxtil não-tecido e uma geogrelha biaxial foram utilizados para os ensaios, que compreenderam a deformação por fluência sem confinamento e em confinamento para ambos os geossintéticos e na ruptura por fluência, em condição confinada, para o geotêxtil não-tecido. Os resultados mostraram que a utilização de temperaturas elevadas permitiu acelerar a determinação do comportamento em fluência e que o efeito do confinamento se traduz por uma diminuição das taxas de deformação por fluência. Além disso, os resultados dos ensaios de ruptura por fluência na condição confinada indicam que os fatores de redução devido à fluência sugeridos na literatura técnica apresentam-se conservadores.

Palavras chaves: geossintéticos; fluência em geossintéticos; confinamento e temperatura. 



\begin{abstract}
AVESANI, F. P. B. Confined and accelerated creep tests on geosynthetics. 2013. $134 \mathrm{f}$. Dissertation - School of Engineering at Sao Carlos, University of Sao Paulo, Sao Carlos, 2013.
\end{abstract}

The creep behavior is one of the most important properties of geosynthetics used in reinforced soil structures. This parameter is usually characterized by standard tests, using in-isolation specimens, with controlled temperature and humidity conditions. Although their widespread use, these tests present two main concerns: they are time-consuming and may not consider the possibly significant effect of soil confinement. Together, these aspects may lead to expensive tests and conservative results. In order to address them, standard tests could be performed at elevated temperatures and under the confinement of soil. Several approaches have been presented in the technical literature in order to consider each of these aspects, but only independently. Recently, a new apparatus was developed in order to conduct confined and accelerated creep tests using geosynthetics. Thus, both concerns involving standard creep tests (i.e. elevation of the test temperature and specimen under soil confinement) are addressed simultaneously. This work presents a set of creep tests performed under different conditions with this equipment. A non-woven geotextile and a biaxial geogrid were used in these tests, which comprised the creep deformation behavior both in in-isolation and in-soil conditions and geosynthetic creep rupture in condition confined to the non-woven geotextile. Results highlight the importance of both using elevated temperatures to expedite the determination of geosynthetics creep behavior and the effect of soil confinement in lower rates of creep deformations. In addition, it was found that the reduction factors due to creep were considerably lower than those suggested by the literature.

Keywords: geosynthetics; creep on geosynthetics; confinement and temperature. 



\section{LISTA DE FIGURAS}

Figura 2.1 - Curva tensão-deformação - (a) Fluência linear; (b) Dois diferentes tipos de relaxação (adaptado de DEN HOEDT, 1986).

Figura 2.2 - Fases da deformação por fluência em geossintéticos (FRANÇA, 2012). 33

Figura 2.3 - (a) Modelo de Boltzmann; (b) Representação gráfica do comportamento deste modelo (adaptado de DEAN; BROUGHTON, 2007).

Figura 2.4 - (a) Modelo mecânico; (b) Representação gráfica do comportamento deste modelo (adaptado de SAWICKI; KAZIMIEROWICZ-FRANKOWSKA, 1998). 35

Figura 2.5 - Representações gráficas - (a) Tempo em escala natura; (b) Tempo em escala logarítmica (FRANÇA, 2012).

Figura 2.6 - Representação gráfica das deformações por fluência segundo a proposta de Zornberg et al. (2004) (FRANÇA, 2012).

Figura 2.7 - Obtenção das curvas isócronas (BARAS, 2001). 38

Figura 2.8 - Representação da ruptura por fluência de geossintéticos - (a) Obtenção dos tempos; (b) Curva de ruptura por fluência (FRANÇA, 2012). 38

Figura 2.9 - Ilustrações dos comportamentos - (a) Elastoplástico; (b) Termo-visco; (c) Anisotrópico; (d) Cíclico (adaptado de PERKINS, 2000).

Figura 2.10 - Deformação das fibras de um geotêxtil tecido - (a) Sentido longitudinal à aplicação do carregamento; (b) Sentido transversal à aplicação do carregamento (adaptado de DEN HOEDT, 1986).

Figura 2.11 - Curvas de fluência para diferentes tipos de polímeros - (a) $20 \%$ da resistência à tração; (b) 60\% da resistência à tração (adaptado de DEN HOEDT, 1986).

Figura 2.12 - Influência do nível de carregamento no comportamento da fluência em geossintéticos (adaptado de SIMONINI; GOTTARDI, 2003).

Figura 2.13 - Efeito da velocidade de carregamento na fluência de uma geogrelha de submetida a $40 \%$ da resistência à tração (traduzido de RIMOLDI; MONTANELLI, 1993).

Figura 2.14 - Relação entre a temperatura e deformações por fluência de uma geomembrana de poliamida (adaptado de SCAFFARO et al., 2008).

Figura 2.15 - Comparação entre ensaio confinado e não confinado (COSTA, 1999). 46

Figura 2.16 - Resultados dos ensaios de fluência de geotêxteis não-tecidos - (a) Termoligado, 33\% PEAD e 67\% PP; (b) Agulhado, 100\% PET (adaptado de MCGOWN et al., 
1982)

Figura 2.17 - Curvas de fluência dos ensaios acelerado e confinado-acelerado conduzidos em geotêxtil não-tecido de poliéster (FRANÇA et al., 2011). 48

Figura 2.18 - Ensaios de fluência realizados em uma geogrelha de poliéster - (a) Ensaio convencional e acelerado; (b) Ensaio confinado e ensaio confinado e acelerado (adaptado de FRANÇA; BUENO, 2011). 49

Figura 2.19 - Combinação entre degradação química e fluência de fibras de poliéster - (a) Perda de resistência; (b) Fatores de redução (adaptado de TRENTINI et al., 2006)... 50 Figura 2.20 - Equipamento utilizado na realização dos ensaios de fluência convencional (adaptado de ASTM D 5262, 2007). 51

Figura 2.21 - Translação horizontal dos resultados de ensaios de fluência conduzidos em temperaturas diferentes com o mesmo nível de carregamento (adaptado de FARRAG, 1998) 53

Figura 2.22 - Fatores de translação pela equação de WLF (adaptado de FARRAG, 1998). .. 54 Figura 2.23 - Obtenção da curva mestra pelo método SIM - (a) Dados em escala natural; (b) Dados em escala logarítmica; (c) Curva mestra (adaptado de ZORNBERG et al., 2004)

Figura 2.24 - Modelo de ensaios no qual a carga é aplicada diretamente ao geossintético (adaptado de COSTA, 2004). 58

Figura 2.25 - Equipamento para ensaio de fluência confinada em geotêxteis (adaptado de MCGOWN et al., 1982). 59

Figura 2.26 - Modelo de ensaios no qual o solo solicita o geossintético (adaptado de COSTA, 2004)

Figura 2.27 - Equipamento utilizado para ensaios confinado e acelerado em geossintéticos (FRANÇA et al., 2011).

Figura 2.28 - Fator de redução devido à fluência obtido através da curva de ruptura por fluência (COSTA, 1999).

Figura 3.1 - (a) Equipamento de fluência confinada e acelerada em geossintéticos; (b) Fotografia do ensaio em execução (FRANÇA, 2012). ................................................. 66

Figura 3.2 - Compartimento superior e inferior da câmara de ensaios. 66

Figura 3.3 - Sequência de preparação dos corpos de prova - (a) Fases do preparo e aplicação do adesivo; (b) Dimensões do corpo de prova (FRANÇA, 2012). 68

Figura 3.4 - Configuração final do corpo de prova de geossintético, com destaque para a 
medida da distância entre os pontos de fixação.

Figura 3.5 - Envoltória de resistências dos ensaios de cisalhamento direto (adaptado de FRANÇA, 2012).

Figura 3.6 - Sequência de montagem do sistema de reprodução do confinamento (FRANÇA, 2012)

Figura 3.7 - Sistema de aquecimento e posicionamento do termopar ativo (FRANÇA, 2012).

Figura 3.8 - Sistema de aplicação da solicitação de tração (FRANÇA, 2012). 72

Figura 3.9 - (a) Procedimento de calibração das células de carga; (b) Curvas de calibração.. 72 Figura 3.10 - Calibração da célula de carga quando acoplada ao equipamento de fluência confinada e acelerada.

Figura 3.11 - Posicionamento dos elementos de medição do alongamento - (a) Pontos de fixação na área de interesse do corpo de prova; (b) Medição do deslocamento vertical dos elementos metálicos.

Figura 3.12 - Calibração dos transdutores de deslocamento - (a) Procedimento de calibração;

(b) Curvas de calibração.

Figura 3.13 - Equipamentos para aquisição dos dados - (a) Model P3 Strain Indicator and Recorder; (b) Controlador de temperatura.

Figura 3.14 - Acessório empregado para aplicação da solicitação de tração ao corpo de prova de geossintético - (a) Vista frontal; (b) Execução do carregamento em ensaio confinado e acelerado.

Figura 3.15 - Carregamento da solicitação de tração - (a) Ensaio de fluência confinada a 70\% da resistência a tração de um geotêxtil não-tecido; (b) Ensaio de fluência confinada e acelerada a $50 \%$ da resistência a tração de uma geogrelha biaxial.............................. 79

Figura 3.16 - Curva granulométrica do solo confinante utilizado. 81

Figura 3.17 - Etapas de montagem do compartimento superior da câmara de ensaios (FRANÇA, 2012). .83

Figura 3.18 - Relação entre a resistência à tração e a gramatura de cada corpo de prova de geotêxtil não-tecido. 86

Figura 4.1 - Curvas de fluência obtidas nos ensaios convencionais de fluência conduzidos no GTN (comportamento em deformação por fluência para os níveis de carregamento entre 20 e $80 \%$ e ruptura por fluência para o nível de carregamento de $90 \%$ ). .90

Figura 4.2 - Deformações por fluência obtidas nos ensaios convencionais de fluência 
conduzidos no GTN, segundo a proposta de Zornberg et al. (2004).

Figura 4.3 - (a) Índice de fluência e (b) deformação inicial dos corpos de prova em função do nível de carregamento aplicado aos ensaios convencionais de fluência conduzidos no GTN.

Figura 4.4 - Curvas de fluência dos diferentes ensaios de fluência conduzidos no GTN, com nível de carregamento de $50 \%$ da resistência à tração do geossintético.

Figura 4.5 - Deformações por fluência dos diferentes ensaios de fluência conduzidos no GTN, com carregamento de $50 \%$ da resistência à tração desse material.

Figura 4.6 - Deformações iniciais dos corpos de prova empregados nos ensaios de fluência conduzidos no GTN, para o nível de carregamento de $50 \%$ da resistência à tração desse geossintético.

Figura 4.7 - Curvas mestras de fluência do GTN em condição de isolamento e em confinamento em areia, para o nível de carregamento de 50\% da resistência à tração desse geossintético.

Figura 4.8 - Curvas de fluência do GTN obtidas com os corpos de prova em condição confinada e em temperatura ambiente, para os níveis de carregamento entre 95 e $70 \%$ da resistência à tração desse material.

Figura 4.9 - Curvas de fluência dos ensaios confinado e acelerado (CA) e apenas confinado

(C) conduzidos no geotêxtil não-tecido. 102

Figura 4.10 - Curvas de fluência obtidas nos ensaios confinado e acelerado (CA) e apenas confinado (C), para carregamento de $70 \%$ da resistência à tração do GTN.

Figura 4.11 - Curvas mestras de fluência do GTN em condição de confinamento em areia e com tensão normal de $50 \mathrm{kPa}$, para os corpos de prova submetidos a carregamento de 85 e $70 \%$ da resistência à tração do material $\left(\mathrm{T}_{\text {últ }}\right)$.

Figura 4.12 - Curva de ruptura por fluência do GTN obtida com corpos de prova em condição de confinamento em areia e tensão normal de $50 \mathrm{kPa}$. 106

Figura 4.13 - Índice de fluência obtidos nos ensaios de fluência convencional e confinado em função do nível de carregamento aplicado (ensaios com GTN).

Figura 4.14 -Redução do índice de fluência $\left(\mathrm{T}_{\alpha}\right)$ por conta do confinamento em função do nível de carregamento aplicado aos ensaios conduzidos com o GTN. 110

Figura 4.15 - Curvas de fluência obtidas nos ensaios convencionais de fluência conduzidos com a geogrelha biaxial de poliéster (GG).

Figura 4.16 - Deformações por fluência dos ensaios convencionais de fluência conduzidos na 
GG, segundo a proposta de Zornberg et al. (2004).

Figura 4.17 - (a) Índice de fluência e (b) deformação inicial dos corpos de prova em função do nível de carregamento aplicado aos ensaios convencionais de fluência conduzidos na GG

Figura 4.18 - Curvas de fluência obtidas a partir dos ensaios de fluência conduzidos na GG, para o nível de carregamento de 50\% da resistência à tração desse geossintético. ....115

Figura 4.19 - Deformações por fluência obtidas a partir dos ensaios de fluência conduzidos na GG, para o carregamento de $50 \%$ da resistência à tração desse material. 116

Figura 4.20 - Curvas mestras de fluência obtidas para a GG em condição de isolamento e em confinamento em areia, para o nível de carregamento igual a 50\% da resistência à tração desse material. 



\section{LISTA DE TABELAS}

Tabela 2.1 - Fatores de redução sugeridos para geotêxteis (KOERNER, 2005)....................63

Tabela 3.1 - Resultados dos ensaios de caracterização dos geossintéticos..............................8 80

Tabela 3.2 - Resultados da caracterização do solo confinante.

Tabela 3.3 - Características desejadas para os ensaios de fluência realizados em cada tipo de geossintético.

Tabela 3.4 - Solicitação de tração corrigida de cada ensaio de fluência realizado.

Tabela 4.1 - Parâmetros obtidos pelas curvas de regressão logarítmica de cada ensaio convencional conduzido no GTN.

Tabela 4.2 - Índices de fluência obtidos nos ensaios de fluência convencional conduzidos no GTN

Tabela 4.3 - Parâmetros obtidos nas curvas de ajuste (Equação 13) dos pontos experimentais dos ensaios conduzidos no GTN.

Tabela 4.4 - Índice de fluência obtidos nos ensaios de fluência conduzidos no GTN com nível de carregamento de $50 \%$ da resistência à tração desse geossintético. 95

Tabela 4.5 - Comparativo entre os resultados obtidos nesta pesquisa e por França (2012)...997

Tabela 4.6 - Características das curvas mestras de fluência para as condições de isolamento e confinamento (ensaios GTN).

Tabela 4.7 - Parâmetros obtidos a partir das regressões logarítmicas (Equação 13) dos ensaios conduzidos no GTN

Tabela 4.8 - Parâmetros obtidos pelas regressões logarítmicas (Equação 13) a partir dos ensaios conduzidos com carregamento igual a 85\% da resistência à tração do GTN.103

Tabela 4.9 - Parâmetros obtidos a partir das regressões logarítmicas (Equação 13) dos dados experimentais dos ensaios conduzidos com carregamento de $70 \%$ da resistência à tração do GTN.

Tabela 4.10 - Características dos ensaios conduzidos com o GTN.

Tabela 4.11 - Tempo de ruptura por fluência obtido em cada nível de carregamento dos ensaios conduzidos no GTN. 106

Tabela 4.12 - Índice de fluência para cada nível de carregamento e condição de ensaio.

Tabela 4.13 - Parâmetros obtidos através das regressões logarítmicas (Equação 13) dos dados experimentais dos ensaios convencionais conduzidos na GG.

Tabela 4.14 - Índice de fluência obtidos nos ensaios convencionais conduzidos na GG......113 
Tabela 4.15 - Parâmetros obtidos a partir das regressões logarítmicas (Equação 13) dos ensaios de fluência conduzidos na GG................................................................... 115

Tabela 4.16 - Parâmetros obtidos pela regressão linear (Equação 14) dos dados dos ensaios de fluência conduzidos no GG. .................................................................................. 116

Tabela 4.17 - Análises conduzidas nesta pesquisa e realizadas por França (2012). ............ 118

Tabela 4.18 - Informações dos ensaios de fluência conduzidos na geogrelha biaxial de

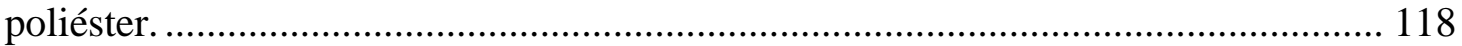

Tabela 4.19 - Características das curvas mestras de fluência para as condições em isolamento

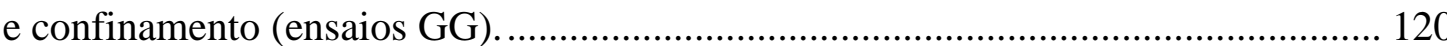




\section{LISTA DE ABREVIATURAS}

A

ABNT

ASTM

BS

C

$\mathrm{C} 1$

$\mathrm{C} 2$

CA

Célula 1

Célula 2

Conv

EESC

FHWA

FR

GG

GTN

ISO

LVDT-1; LVDT-2

NBR

PA

PE

PEAD

PET

PP

SIM

STT

USP

WLF
Ensaio de fluência acelerada

Associação Brasileira de Normas Técnicas

American Society for Testing and Materials

British Standards

Ensaio de fluência confinada

Termopar ativo

Termopar passivo

Ensaio de fluência confinada e acelerada

Célula de carga 1

Célula de carga 2

Ensaio de fluência convencional

Escola de Engenharia de São Carlos

Federal Highway Administration

Fator de redução

Geogrelha biaxial de poliéster empregada nesta pesquisa

Geotêxtil não-tecido de poliéster empregado nesta pesquisa

International Organization for Standardization

Transdutores de deslocamento 1 e 2

Norma Brasileira

Poliamida

Polietileno

Polietileno de alta densidade

Poliéster

Polipropileno

Stepped Isothermal Method

Superposição tempo-temperatura

Universidade de São Paulo

Equação de Williams, Landel e Ferry (1955) 



\section{LISTA DE SÍMBOLOS}

\begin{tabular}{|c|c|}
\hline$\varepsilon$ & Deformação total \\
\hline$\varepsilon_{0}$ & Deformação inicial \\
\hline$\varepsilon_{\mathrm{f}}$ & Deformação por fluência \\
\hline$\varepsilon_{1}$ & Deformação primária da fluência \\
\hline$\varepsilon_{2}$ & Deformação secundária da fluência \\
\hline$\varepsilon_{3}$ & Deformação terciária da fluência \\
\hline$\sigma_{\mathrm{o}}$ & Solicitação de tração aplicada inicial \\
\hline$\sigma_{\mathrm{f}}$ & Solicitação de tração aplicada final \\
\hline$\sigma$ & Solicitação de tração aplicada \\
\hline $\mathrm{E}_{1}$ e $\mathrm{E}_{2}$ & Rigidez elástica das molas empregadas nos modelos mecânicos \\
\hline$\eta$ & Viscosidade empregada nos modelos mecânicos \\
\hline $\mathrm{R}_{1}$ e $\mathrm{R}_{2}$ & Rigidez plástica empregados nos modelos mecânicos \\
\hline$\Delta \varepsilon$ & Variação da deformação \\
\hline$\varepsilon^{\mathrm{res}}$ & Deformação residual \\
\hline $\mathrm{t}$ & Tempo decorrido no ensaio \\
\hline $\mathrm{a}, \mathrm{b}$ & Constantes da regressão logarítmica das curvas de fluência \\
\hline $\mathrm{T}_{\alpha}$ & Índice de fluência \\
\hline $\mathrm{t}_{0}$ & Tempo para o final do carregamento \\
\hline$\varepsilon_{1-1}, \varepsilon_{1-2}, \varepsilon_{1-\mathrm{n}}$ & Deformação dos corpos de prova no tempo $t_{1}$, para os carregamentos $Q_{n}$ \\
\hline $\mathrm{Q}_{1}, \mathrm{Q}_{2}, \mathrm{Q}_{\mathrm{n}}$ & Níveis de carregamento considerados nas curvas isócronas \\
\hline $\mathrm{t}_{1}, \mathrm{t}_{2}, \mathrm{t}_{\mathrm{n}}$ & Tempos considerados nas curvas isócronas \\
\hline $\mathrm{T} / \mathrm{T}_{\text {últ }}$ & Nível de carregamento relacionado a resistência à tração do geossintético \\
\hline $\mathrm{t}_{60 \%}, \mathrm{t}_{70 \%}, \mathrm{t}_{\mathrm{n}} \%$ & Tempo para que ocorra ruptura por fluência para um dado carregamento \\
\hline $\mathrm{T}_{\mathrm{m}}$ & Temperatura de fusão cristalina \\
\hline $\mathrm{T}_{\mathrm{g}}$ & Temperatura de transição vítrea \\
\hline $\mathrm{T}_{0}$ & Temperatura de referência \\
\hline $\mathrm{T}_{\mathrm{f}}$ & Resistência à tração do geossintético \\
\hline
\end{tabular}




\begin{tabular}{|c|c|}
\hline $\mathrm{T}_{1}$ e $\mathrm{T}_{2}$ & Temperaturas elevadas \\
\hline$\dot{\varepsilon}_{1}$ e $\dot{\varepsilon}_{2}$ & Taxa de deformação para as temperaturas $\mathrm{T}_{1}$ e $\mathrm{T}_{2}$, respectivamente \\
\hline $\mathrm{E}$ & Energia de ativação \\
\hline $\mathrm{R}$ & Constante universal dos gases \\
\hline $\mathrm{a}_{\mathrm{T}}$ & Fator de translação (shift factor) \\
\hline $\mathrm{t}_{\mathrm{i}}$ & Tempo para que o processo ocorra na temperatura elevada \\
\hline$t_{R}$ & Tempo para que o processo ocorra na temperatura de referência \\
\hline $\mathrm{C}_{1}$ e $\mathrm{C}_{2}$ & Constantes empíricas da equação WLF (William, Landel e Ferry, 1955) \\
\hline $\mathrm{T}_{\alpha, \mathrm{i}}$ & Índice de fluência do ensaio com temperatura elevada \\
\hline $\mathrm{T}_{\alpha, \mathrm{R}}$ & Índice de fluência do ensaio na temperatura de referência \\
\hline $\mathrm{T}_{\mathrm{adm}}$ & Resistência à tração admissível do geossintético \\
\hline $\mathrm{T}_{\text {últ }}$ & Resistência à tração do geossintético \\
\hline $\mathrm{FR}_{\mathrm{DI}}$ & Fator de redução devido a danos de instalação \\
\hline $\mathrm{FR}_{\mathrm{F}}$ & Fator de redução devido à fluência \\
\hline $\mathrm{FR}_{\mathrm{DQ}}$ & Fator de redução devido à degradação química \\
\hline $\mathrm{FR}_{\mathrm{DB}}$ & Fator de redução devido à degradação biológica \\
\hline$f_{\mathrm{m}}$ & Fator de redução devido a incertezas estatísticas da resistência \\
\hline $\mathrm{T}_{\text {fluência }}$ & $\begin{array}{l}\text { Solicitação máxima que o geossintético pode ser submetido em sua vida } \\
\text { útil }\end{array}$ \\
\hline $\mathrm{L}_{\mathrm{i}}$ & Distância inicial entre os pontos de fixação dos fios inextensíveis \\
\hline $\mathrm{D}_{\mathrm{A}}$ e $\mathrm{D}_{\mathrm{B}}$ & Leitura dos deslocamentos de cada transdutor de deslocamento \\
\hline $\mathrm{T}$ & Resistência à tração do geotêxtil \\
\hline $\mathrm{G}$ & Gramatura do geotêxtil \\
\hline $\mathrm{RT}_{\alpha}$ & Redução do índice de fluência \\
\hline
\end{tabular}




\section{SUMÁRIO}

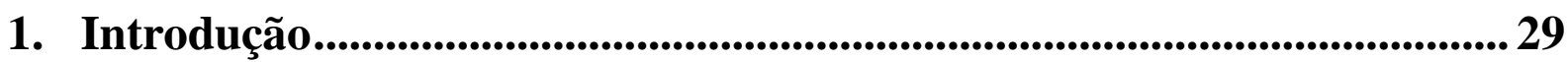

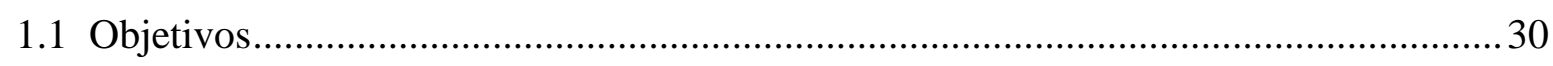

2. Revisão Bibliográfica ................................................................................31

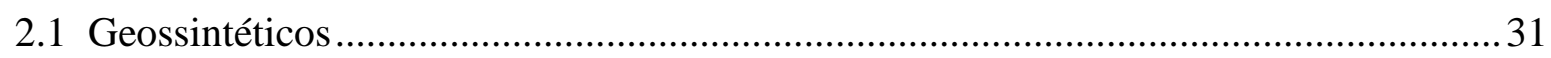

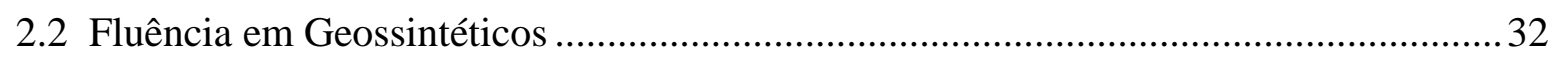

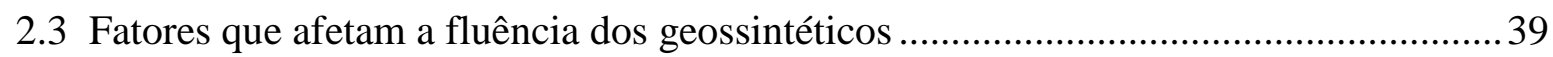

2.3.1 Tipo de geossintético e polímero constituinte ..................................................... 40

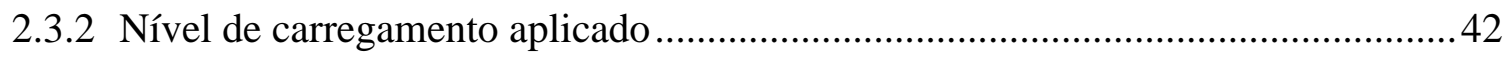

2.3.3 Velocidade de aplicação do carregamento ......................................................... 43

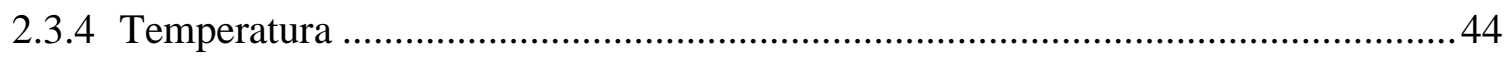

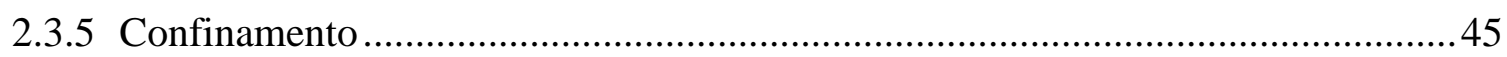

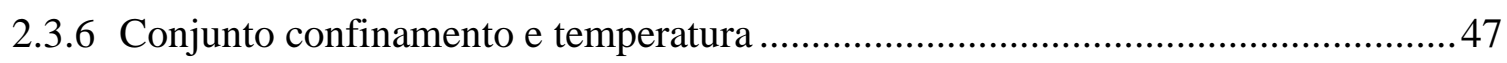

2.3.7 Combinação entre diversos tipos de degradação..................................................50

2.4 Ensaios para determinação da fluência em geossintéticos .........................................50

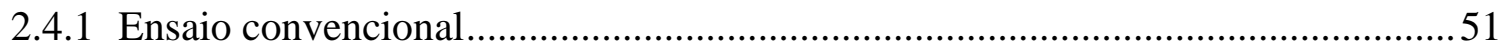

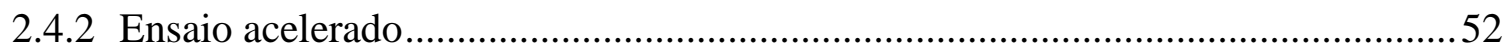

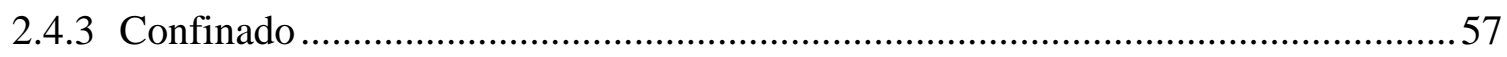

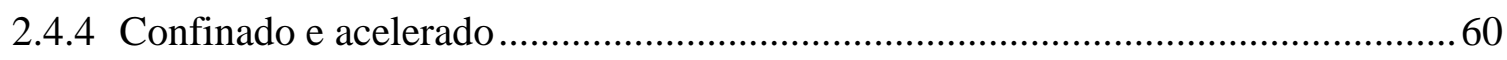

2.5 Importância e aplicação da fluência em estruturas de solo reforçado ...........................62

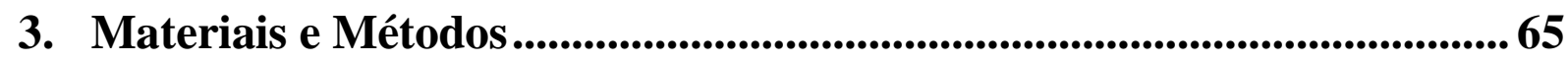

3.1 Descrição do equipamento de fluência confinada e acelerada ....................................65

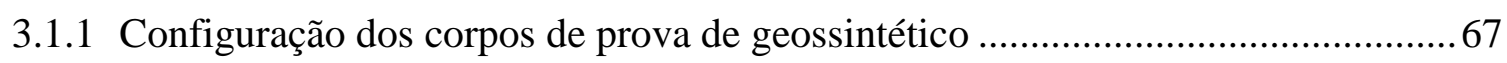

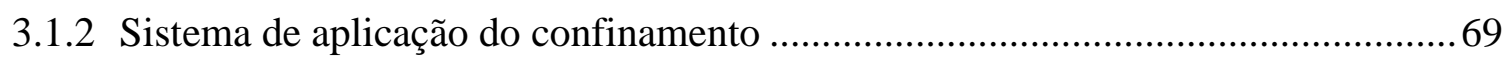

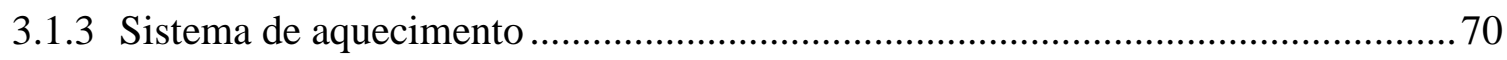

3.1.4 Sistema de aplicação da solicitação de tração..................................................... 71

3.1.5 Sistema de medição do alongamento do corpo de prova ...................................... 74

3.1.6 Sistemas de aquisição de dados...................................................................... 76

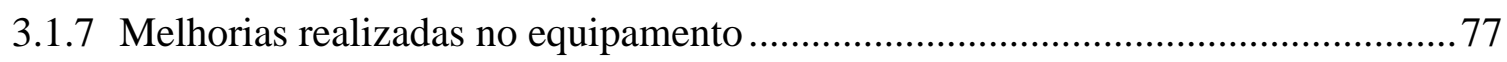

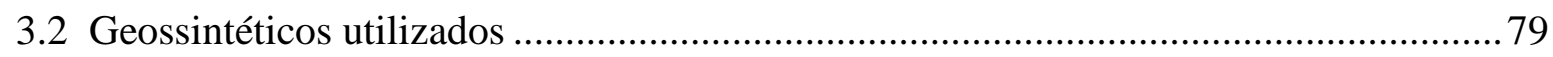

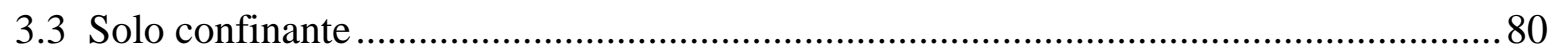




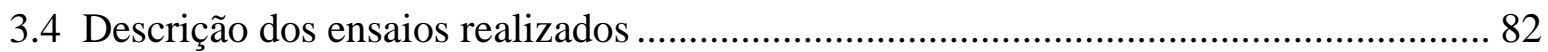

3.4.1 Montagem do ensaio de fluência confinada e acelerada .................................... 83

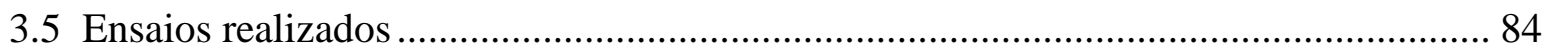

4. Resultados e Discussões ......................................................................89

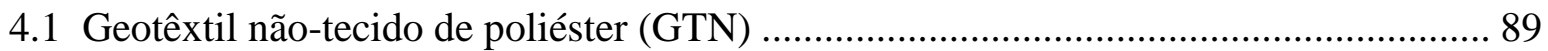

4.1.1 Avaliação da influência do confinamento e da temperatura no comportamento em

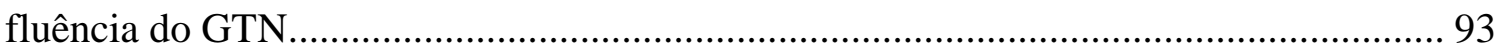

4.1.2 Avaliação do comportamento na ruptura por fluência para condição confinada do GTN 100

4.2 Geogrelha biaxial de poliéster (GG)

4.2.1 Avaliação da influência do confinamento e da temperatura no comportamento em

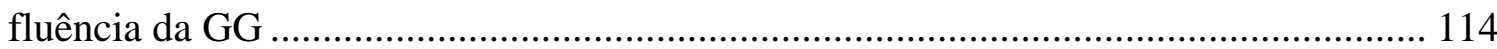

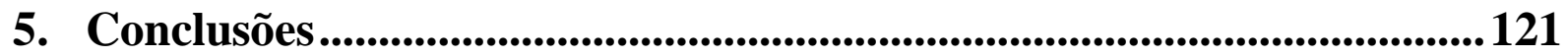

6. Proposta para Estudos Futuros ........................................................125

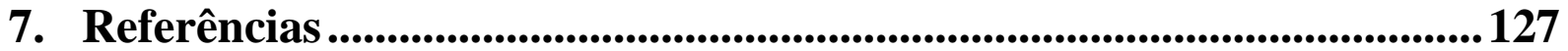




\section{Introdução}

A fluência é um fenômeno rotineiramente considerado na determinação da resistência à tração de geossintéticos utilizados em projetos de solos reforçados. Em geral, sua influência é considerada por meio da adoção de um fator de redução da resistência. Este fator pode ser quantificado a partir da realização de ensaios de fluência ou com base em valores típicos referidos na literatura. O comportamento em fluência dos geossintéticos geralmente é caracterizado a partir dos ensaios padronizados de fluência (NBR 15.226 e ASTM D 5262), que são realizados sob condições controladas de temperatura e umidade relativa do ar. No entanto, esta técnica apresenta duas deficiências: o tempo necessário para obtenção de uma resposta significativa quanto a esse comportamento (podendo alcançar até 10.000 horas de ensaio), bem como o fato de não considerar o efeito da interação do solo com o geossintético (confinamento em solo).

Uma das alternativas para contornar essas limitações é acelerar a resposta da fluência por meio da elevação da temperatura dos ensaios padronizados de fluência. Este procedimento é denominado ensaio acelerado de fluência e trata-se de um método muito bem estabelecido na literatura técnica, contando com uma abordagem descrita pela ASTM D 6992 (Stepped Isothermal Method). Por outro lado, o fato dos ensaios padronizados de fluência não levarem em consideração a interação entre o solo e o geossintético, pode ser contornado com a realização de ensaios em câmaras especiais, onde os corpos de prova são confinados em solo. Essa abordagem foi iniciada por McGown et al. (1982) e, posteriormente diversos estudos foram divulgados na literatura técnica, empregando-se diferentes tipos de equipamentos. Embora haja um grande número de publicações disponíveis, ainda não foi estabelecido um procedimento padronizado para execução desse tipo de ensaios. Assim, tanto ensaios com elevação da temperatura, quanto de confinamento em solo são relatados com sucesso na literatura técnica, mas apenas de forma independente. No entanto, França (2012) apresentou um equipamento que é capaz de conduzir simultaneamente ensaios de fluência confinados e acelerados.

Este trabalho apresenta um conjunto de resultados de ensaios de fluência realizados sob diferentes condições utilizando este equipamento. Nesse sentido, buscaram-se informações sobre o efeito do confinamento e da temperatura em um geotêxtil não-tecido e 
uma geogrelha biaxial, ambos de poliéster. Adicionalmente, apresentam-se e discutem-se os resultados dos ensaios de ruptura por fluência na condição confinada realizados no geotêxtil não-tecido, mostrando que os fatores de redução devido à fluência sugeridos pela literatura técnica apresentam-se conservadores.

\subsection{Objetivos}

O interesse pelo conhecimento do efeito da fluência dos geossintéticos em obras geotécnicas vem crescendo a cada dia, tornando-se necessária uma melhor compreensão desse fenômeno. Desta forma, a fim de complementar os estudos existentes sobre esse assunto, os ensaios de fluência abordados neste trabalho seguem os seguintes objetivos específicos:

a) Realizar ensaios em dois tipos de geossintéticos, avaliando a influência do confinamento e da temperatura no comportamento em fluência desses materiais. Esses resultados serão comparados aos ensaios padronizados de fluência.

b) Realizar ensaios de ruptura por fluência em condição confinada para o geotêxtil não-tecido, a fim de avaliar o efeito deste parâmetro no tempo de ruptura por fluência desse material. Esses resultados serão empregados na determinação do fator de redução devido à fluência e posteriormente comparados aos valores praticados no âmbito de projeto de solos reforçados. 


\section{Revisão Bibliográfica}

Este capítulo apresenta um contexto geral sobre o comportamento da fluência em geossintéticos, tais esclarecimentos são necessários para o entendimento dos pontos abordados ao longo deste trabalho.

\subsection{Geossintéticos}

A Associação Brasileira de Normas Técnicas NBR 12.553 define geossintéticos como produtos poliméricos (sintéticos ou naturais), industrializados, desenvolvidos para utilização em obras geotécnicas, desempenhando uma ou mais funções.

As primeiras utilizações dos geotêxteis foram como elemento filtrante, aplicados na Holanda e nos EUA, em muros de concreto, para controle de erosão e como elemento de separação em "rip-raps" (BUENO, 2004). No Brasil, os geossintéticos são empregados desde a década de 70 , principalmente em sistemas de drenagem. No início da década de 80 foi executada a primeira obra de solo reforçado com geotêxtil, na rodovia que liga as cidades de Taubaté a Campos de Jordão, no estado de São Paulo. Desde então, os geossintéticos vêm desempenhando um papel fundamental, substituindo e aprimorando técnicas existentes, permitindo associações e combinações com solos e agregados, resultando em soluções mais rápidas, mais leves, mais esbeltas, mais confiáveis e mais baratas (VERTEMATTI, 2004).

Os tipos de geossintéticos mais empregados como elementos de reforço de solo são os geotêxteis e as geogrelhas. Os geotêxteis são definidos como produtos bidimensionais permeáveis, compostos por fibras cortadas, filamentos contínuos, monofilamentos, laminetes ou fios, formando estruturas tecidas, não tecidas ou tricotadas. As geogrelhas são produtos com estrutura em forma de grelha, cujas aberturas permitem a interação com o meio em que está confinada, constituída por elementos resistentes à tração. É considerada unidirecional quando apresenta elevada resistência à tração em apenas uma direção e, bidirecional para as duas direções principais (AGUIAR; VERTEMATTI, 2004).

Os geossintéticos são constituídos essencialmente por polímeros e, em menor escala por aditivos, que tem por finalidade introduzir melhorias ao processo de fabricação e modificar o comportamento do polímero básico (BUENO, 2004). 


\subsection{Fluência em Geossintéticos}

Os geossintéticos apresentam um comportamento tensão-deformação dependente do tempo, no qual é necessário definir dois tipos de comportamento: fluência e relaxação (KAZIMIEROWICZ-FRANKOWSKA, 2005). A fluência é caracterizada pelo desenvolvimento de deformações ao longo do tempo em um material submetido a uma solicitação constante e decorre de natureza viscoelástica desse material (CAZZUFI et al., 1997). A relaxação, por outro lado, corresponde a uma diminuição da carga, no decorrer do tempo, quando a deformação do material é impedida e permanece constante com o passar do tempo (COSTA, 2004). A Figura 2.1 ilustra os fenômenos de fluência e relaxação, respectivamente. Na situação em fluência (Figura 2.1a), mantendo-se um carregamento ( $\sigma$ ), a deformação $(\varepsilon)$ aumenta em função do tempo. Por outro lado, na situação de relaxação (Figura $2.1 b)$, mantendo-se a deformação $(\varepsilon)$ constante, o carregamento $(\sigma)$ diminui com o tempo.

a) $\varepsilon(\%)$

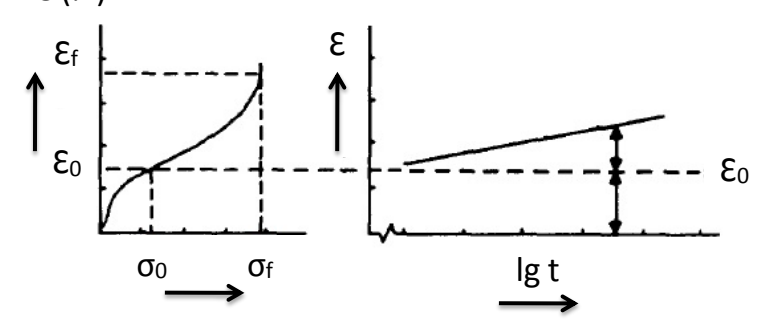

b)

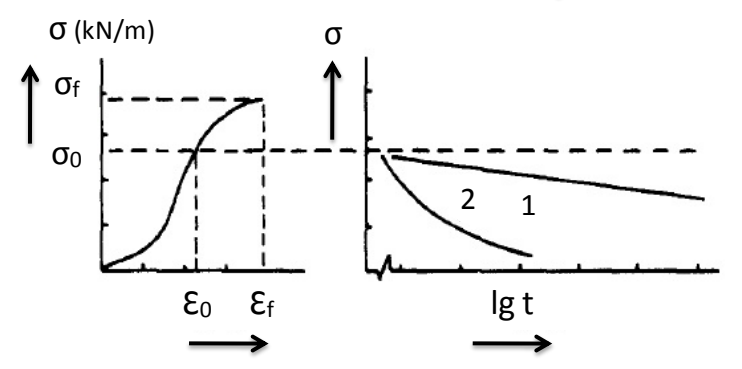

Figura 2.1 - Curva tensão-deformação - (a) Fluência linear; (b) Dois diferentes tipos de relaxação (adaptado de DEN HOEDT, 1986).

A deformação por fluência dos geossintéticos pode ser dividida em três fases (CAZZUFI et al., 1997). A Figura 2.2 exemplifica esse comportamento através de um ensaio de fluência conduzido por França (2012). 


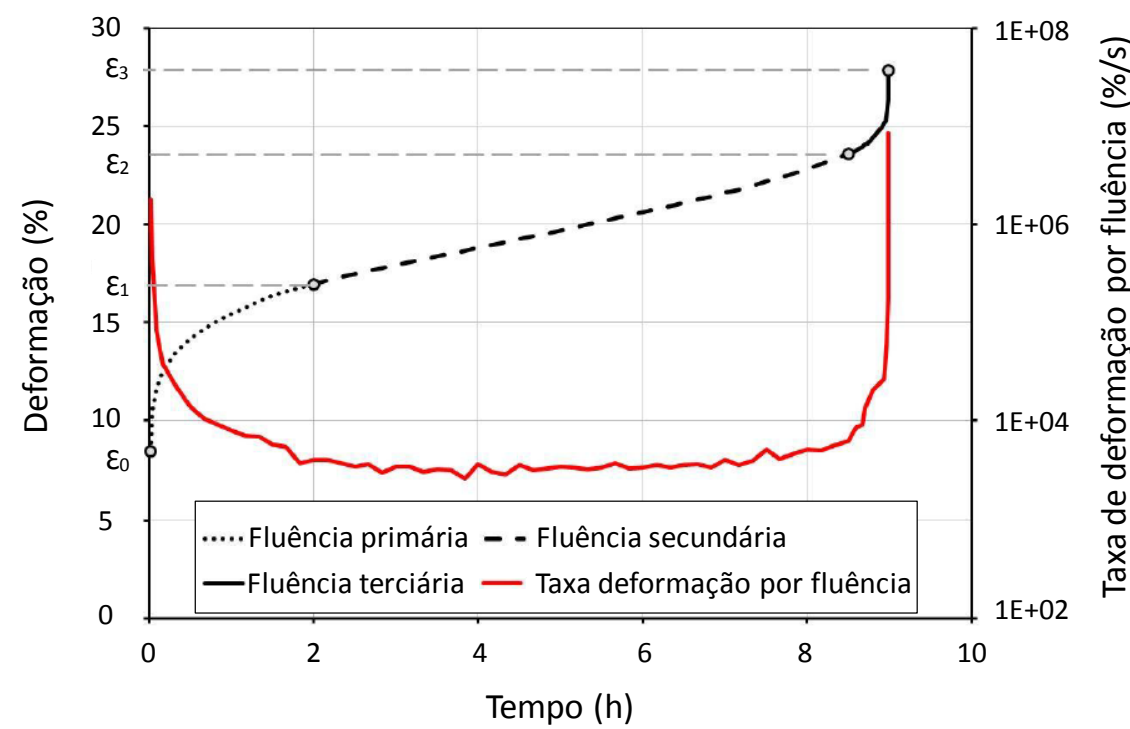

Figura 2.2 - Fases da deformação por fluência em geossintéticos (FRANÇA, 2012).

Conforme se observa na Figura 2.2, quando os geossintéticos são submetidos a um carregamento, apresentam uma deformação imediata, de caráter elástico $\left(\varepsilon_{0}\right)$. Caso esse carregamento seja mantido, as deformações por fluência começam a se processar. Na fluência primária $\left(\varepsilon_{1}\right)$ as deformações se desenvolvem rapidamente, ao passo que a taxa de deformação decresce (primeiro trecho da curva). Se plotado em escala logarítmica de tempo, apresenta-se aproximadamente linear. Na fluência secundária $\left(\varepsilon_{2}\right)$ a taxa de deformação torna-se praticamente constante com o tempo. Apresenta comportamento linear quando representada em escala de tempo normal e logarítmica (segundo trecho da curva). O último trecho da curva é caracterizado pela fluência terciária $\left(\varepsilon_{3}\right)$. Essa fase apresenta uma taxa de fluência crescente de deformação, ocasionando a ruptura do material. Sua representação gráfica é curvilínea para ambas as escalas de tempo (natural e logarítmica).

A deformação total ( $\varepsilon$ ) é o somatório das parcelas de deformação (Equação 1), sendo também definida como o somatório das deformações inicial $\left(\varepsilon_{0}\right)$ e por fluência $\left(\varepsilon_{\mathrm{f}}\right)$.

$$
\varepsilon=\varepsilon_{0}+\varepsilon_{1}+\varepsilon_{2}+\varepsilon_{3}
$$

onde $\varepsilon$ é a deformação total; $\varepsilon_{0}$ a deformação inicial; $\varepsilon_{1}, \varepsilon_{2}$, e $\varepsilon_{3}$ são as deformações por fluência primária, secundária e terciária, respectivamente.

Segundo Bueno et al. (2005), o carregamento aplicado ao geossintético pode gerar tanto o escorregamento entre as fibras, caracterizado como fluência estrutural, como em longo 
prazo, à extensão das fibras formadoras do geossintético (fluência intrínseca). Entretanto, o estudo da fluência de geossintéticos em geotecnia é conduzido comumente apenas para a fluência estrutural.

Alguns modelos mecânicos representam o comportamento viscoelásticos dos materiais, sendo geralmente o de Boltzmann e de Burger os mais aplicados. O modelo de Boltzmann (Figura 2.3) apresenta uma boa aproximação do regime de fluência primária, sendo o mais simples para representar as deformações dependentes do tempo. Este modelo é composto por uma solicitação de tração $(\sigma)$ que provoca uma deformação elástica imediata $\left(\varepsilon_{0}\right)$ que é função da rigidez elástica $\left(\mathrm{E}_{1}\right)$. Caso esse carregamento persista, ocorrem deformações por fluência relacionada à viscosidade $(\eta)$ e à rigidez elástica $\left(E_{2}\right)$.

a)

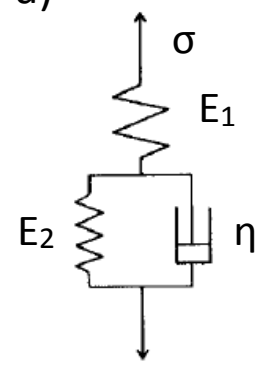

b) $\varepsilon$

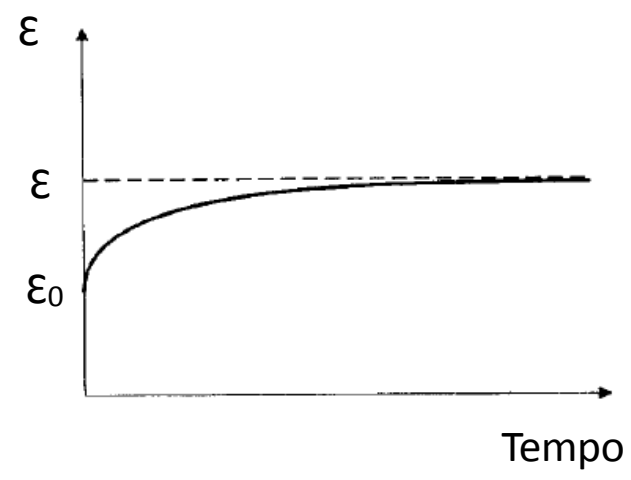

Figura 2.3 - (a) Modelo de Boltzmann; (b) Representação gráfica do comportamento deste modelo (adaptado de DEAN; BROUGHTON, 2007).

Outro modelo é a proposta final de Sawicki e Kazimierowicz-Frankowska (1998), que prevê não só as deformações ao longo do tempo com carregamentos constantes, mas também a parcela recuperável após o descarregamento, pois é apresentado para casos de carregamento seguidos de descarregamento (Figura 2.4). Neste modelo, um determinado carregamento $(\sigma)$ provoca uma deformação imediata $\left(\varepsilon_{0}\right)$, em função da parcela elástica $\left(\mathrm{E}_{1}\right)$ e plástica $\left(R_{1}\right)$. Se o carregamento for mantido, deformações por fluência ocorrem sob influência da viscosidade $(\eta)$ e pelas componentes elástica $\left(E_{2}\right)$ e plástica $\left(R_{2}\right)$. 


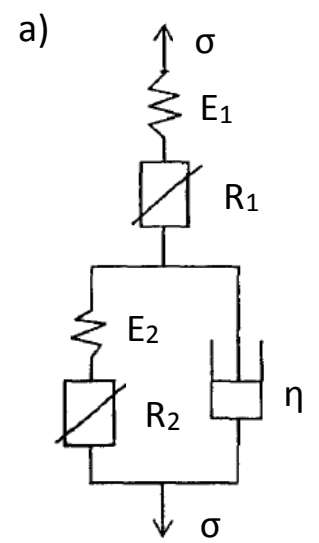

b)

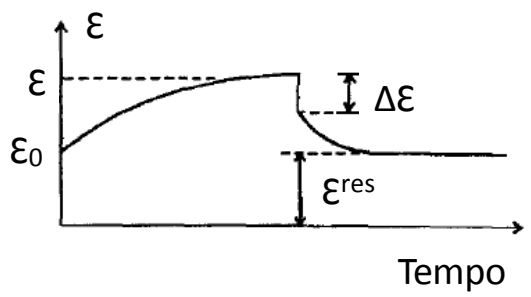

Figura 2.4 - (a) Modelo mecânico; (b) Representação gráfica do comportamento deste modelo (adaptado de SAWICKI; KAZIMIEROWICZ-FRANKOWSKA, 1998).

A fluência dos geossintéticos é geralmente representada por gráficos que relacionam as deformações dos corpos de prova em função do tempo de ensaio, a partir do início da aplicação do carregamento. O tempo pode ser plotado em escala natural ou logarítmica (mais usual). A Figura 2.5 exemplifica as representações gráficas com o tempo em escala natural e logarítmica, respectivamente.

O trecho linear apresentado nos resultados em escala logarítmica de tempo (Figura 2.5b) corresponde às fases primária e secundária da fluência, e podem ser representadas pela Equação 2.

$$
\varepsilon=a \cdot \log (t)+b
$$

onde $\varepsilon$ é a deformação total; $t$ o tempo de ensaio; $a$ e $b$ são constantes empregadas para realizar o ajuste linear dos dados em escala semi-logarítmica. A constante $a$ indica a taxa de deformação por fluência e $b$ a deformação inicial.

Conforme citado anteriormente, pode-se dividir a deformação total em duas parcelas, ou seja, deformação inicial $\left(\varepsilon_{0}\right)$ devido ao carregamento e deformação por fluência $\left(\varepsilon_{\mathrm{f}}\right)$. Esta relação é apresentada na Equação 3.

$$
\varepsilon=\varepsilon_{0}+\varepsilon_{\mathrm{f}}
$$



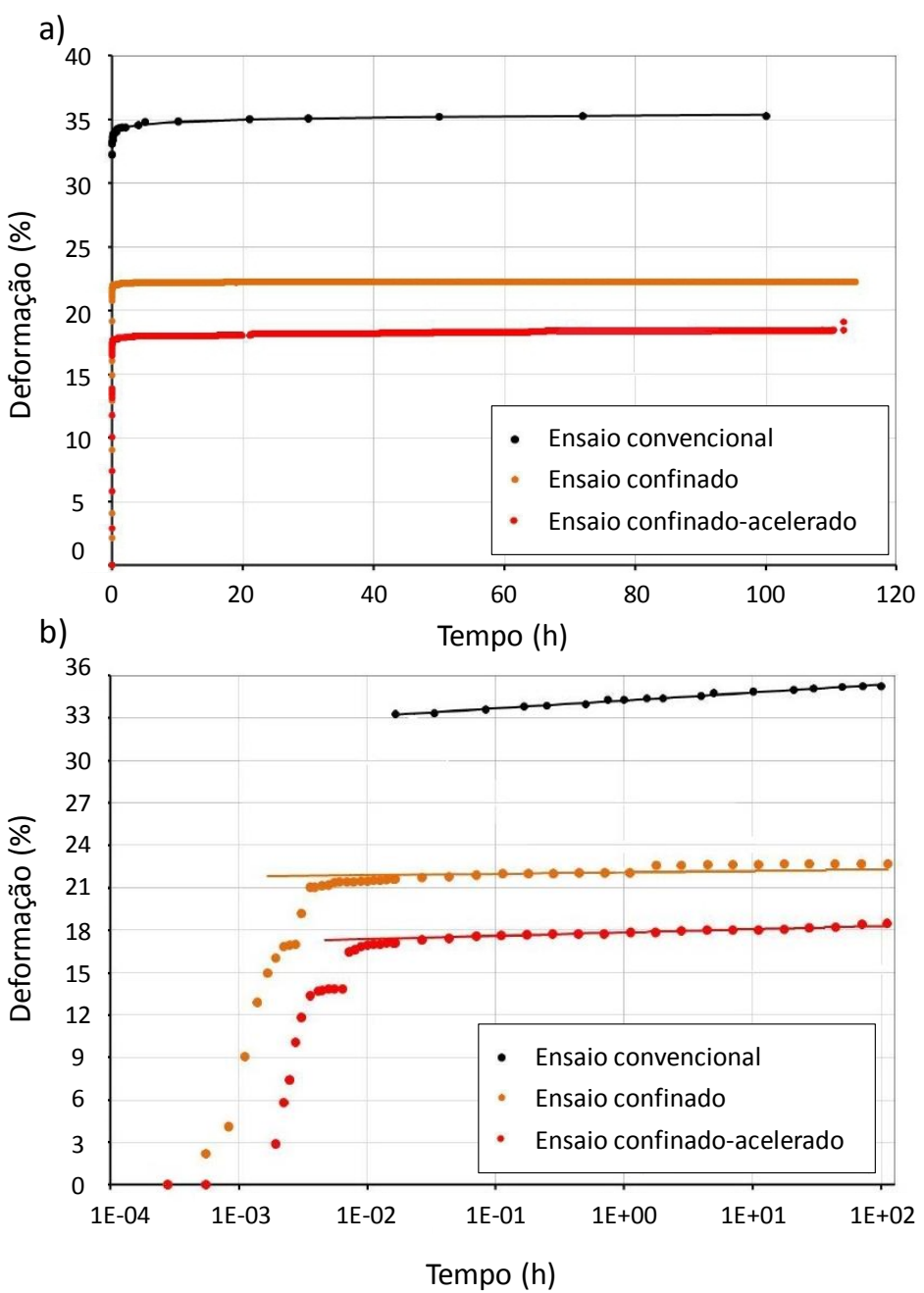

Figura 2.5 - Representações gráficas - (a) Tempo em escala natura; (b) Tempo em escala logarítmica (FRANÇA, 2012).

Zornberg et al. (2004) apresentam um modelo de representação das deformações por fluência nos geossintéticos, em que as deformações por fluência $\left(\varepsilon_{\mathrm{f}}\right)$ são caracterizadas pela inclinação do trecho linear das curvas de fluência, nomeada como índice de fluência $\left(\mathrm{T}_{\alpha}\right)$, e determinada através da Equação 4.

$$
\varepsilon_{\mathrm{f}}=\mathrm{T}_{\alpha} \cdot \log _{10} \frac{t}{t_{0}}
$$

onde $t$ é um valor de tempo qualquer e $t_{0}$ o tempo para o final de aplicação do carregamento, correspondente a deformação $\left(\varepsilon_{0}\right)$.

A partir dessa representação é possível visualizar a influência de cada condição na fluência do material, levando-se em consideração que o índice de fluência representa a 
velocidade com que as deformações por fluência ocorrem. A Figura 2.6 exemplifica a representação gráfica proposta por Zornberg et al. (2004), a partir do conjunto de dados apresentados na Figura 2.5b.

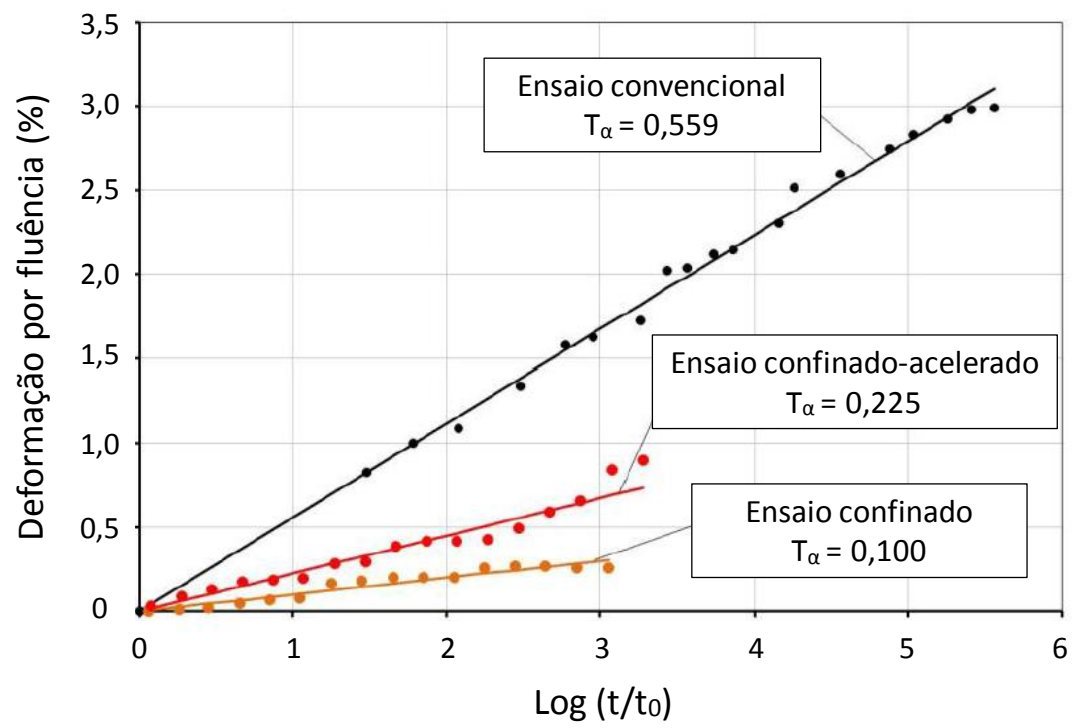

Figura 2.6 - Representação gráfica das deformações por fluência segundo a proposta de Zornberg et al. (2004) (FRANÇA, 2012).

Outro tipo de representação gráfica são as curvas isócronas, obtidas por meio de uma série de ensaios de fluência com diferentes níveis de carregamentos. Estas curvas relacionam a carga aplicada com deformação, para diferentes valores de tempo prédeterminados (BARAS, 2001). A Figura 2.7 ilustra o procedimento para a sua obtenção. Desta forma, considerando-se um tempo $t_{1}$, verifica-se qual a deformação ocorrida para cada nível de carregamento (Q). Em seguida, plotam-se os pontos referentes a esses valores em um gráfico de carregamento aplicado em função da deformação. Repetindo esse procedimento para diversos tempos pré-definidos, definem-se as curvas isócronas. Esse tipo de curva é fundamental para projetos de solos reforçados, onde se podem quantificar as deformações dos geossintéticos ao longo do tempo, importante para a obtenção de parâmetros e análise do estado limite de utilização. 

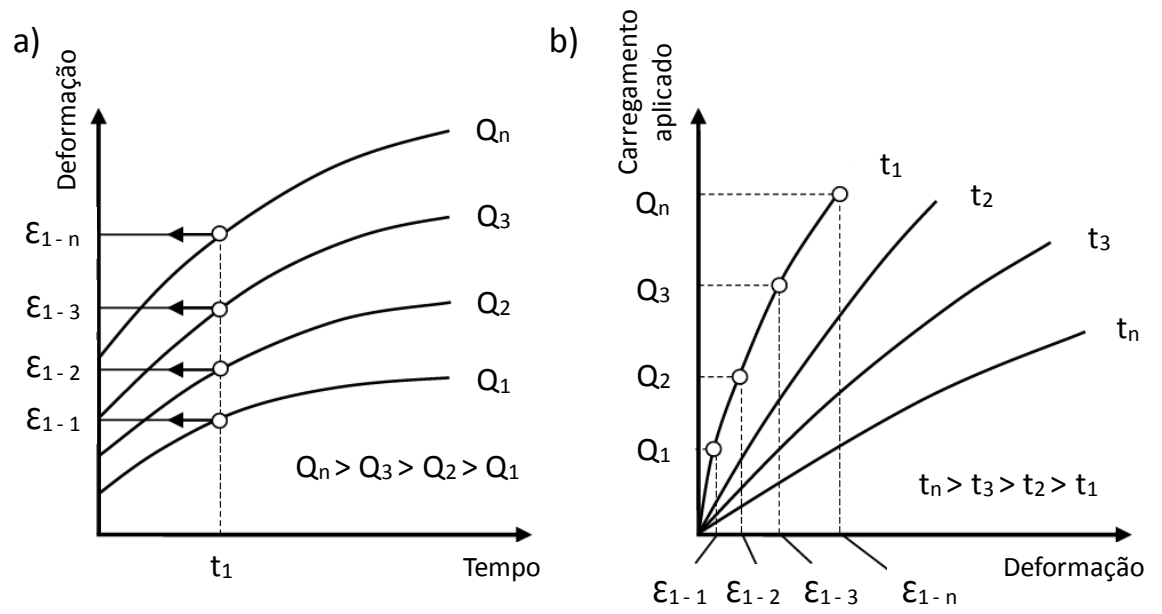

Figura 2.7 - Obtenção das curvas isócronas (BARAS, 2001).

Para projetos onde é importante o estudo do estado limite último, emprega-se uma abordagem diferente do estudo da fluência, ou seja, determina-se o tempo de ocorrência de ruptura por fluência (COSTANZI, 2003). Os ensaios para obtenção da curva de ruptura por fluência são executados com altos níveis de carregamento (60 a 90\%) em relação a resistência à tração. Determinam-se o tempo necessário para que ocorra a ruptura em cada nível de carregamento e, em seguida esses valores são empregados para a construção do gráfico de carga em função do tempo (Figura 2.8). Como esse gráfico apresenta comportamento linear, é comum a extrapolação dos dados para obtenção da carga em tempos maiores. Além disso, são utilizados em projeto para determinar a carga máxima a qual o geossintético poderá ser submetido em sua vida útil.

a)

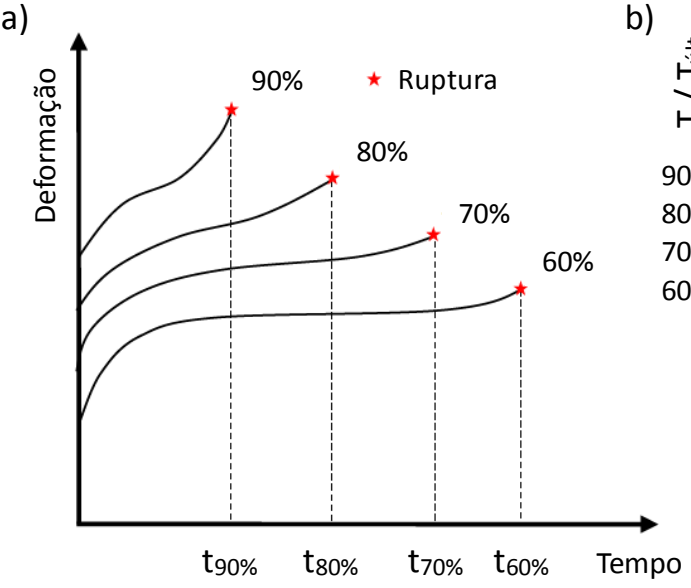

b)

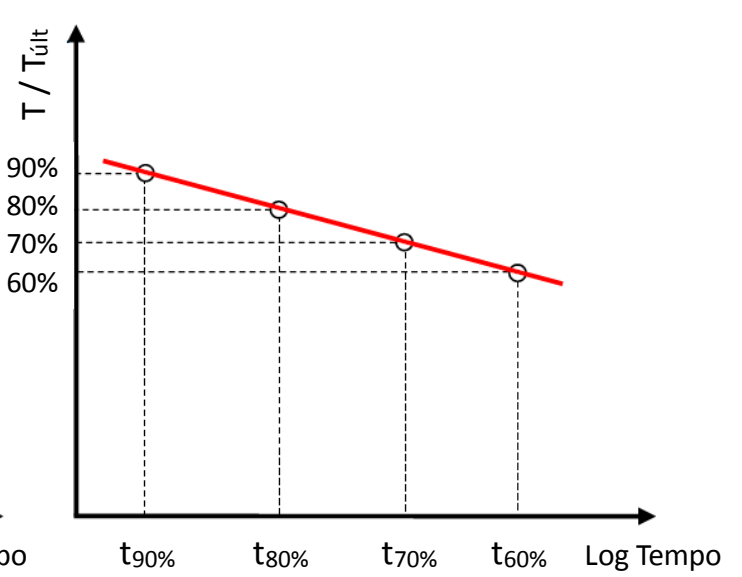

Figura 2.8 - Representação da ruptura por fluência de geossintéticos - (a) Obtenção dos tempos;

(b) Curva de ruptura por fluência (FRANÇA, 2012). 


\subsection{Fatores que afetam a fluência dos geossintéticos}

Os geossintéticos apresentam um comportamento tensão-deformação termo-viscoelasto-plástico dependente da direção do carregamento e, em alguns casos, da tensão normal devido ao confinamento em solo (PERKINS, 2000). A Figura 2.9 ilustra estes casos.

a)
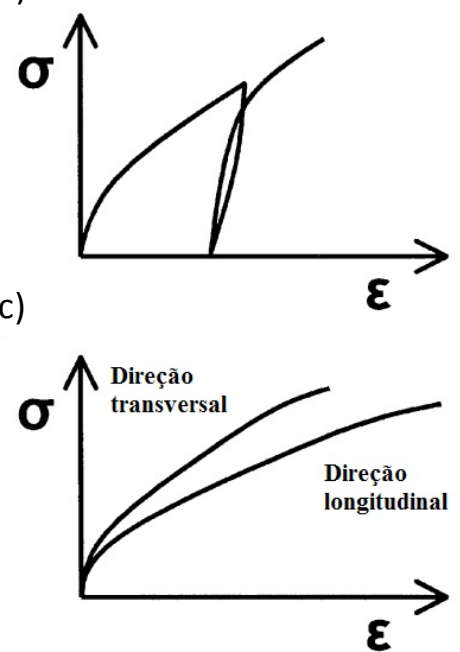

b)

d)
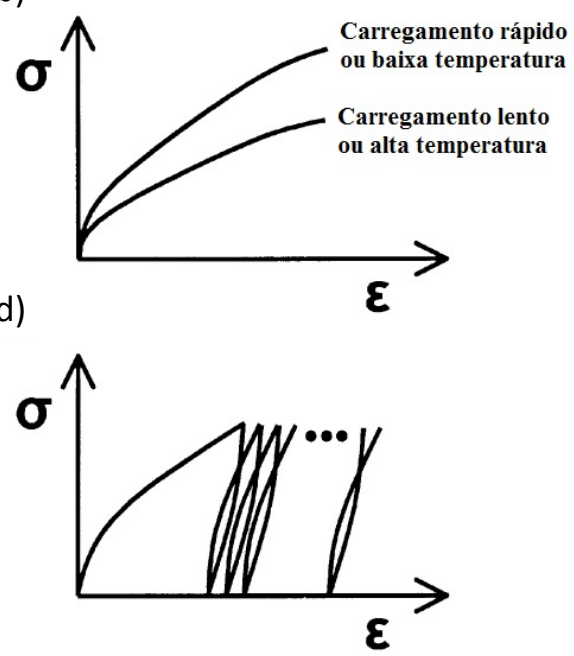

Figura 2.9 - Ilustrações dos comportamentos - (a) Elastoplástico; (b) Termo-visco; (c) Anisotrópico; (d) Cíclico (adaptado de PERKINS, 2000).

A Figura 2.9a ilustra o comportamento tensão-deformação elastoplástico, onde se verifica a ocorrência de uma resposta não linear durante o carregamento. Observa-se uma resposta mais rígida durante o descarregamento. A Figura 2.9b exemplifica a dependência da temperatura e da velocidade de aplicação do carregamento, ou seja, temperaturas mais baixas e/ou carregamentos aplicados mais rapidamente induzem a maiores valores de rigidez do geossintético. Na Figura 2.9c observa-se a dependência da direção de carregamento. O acúmulo de deformações plásticas com a aplicação de ciclos de carregamento (Figura 2.9d) pode influir sobre o comportamento tensão-deformação do geossintético.

Além disso, existem outros fatores que podem afetar o comportamento em fluência dos geossintéticos (DEN HOEDT, 1986; VAN ZANTEN, 1986; CAZZUFI et al., 1997) e serão descritos nos itens a seguir. 


\subsubsection{Tipo de geossintético e polímero constituinte}

O tipo de geossintético e sua forma de fabricação intervêm no desenvolvimento das deformações por fluência. Sheresta e Bell (1982) afirmam que os geotêxteis não-tecidos são mais susceptíveis à fluência do que os tecidos, seguidos pelas geogrelhas.

Den Hoedt (1986) demonstra que o processo de fabricação pode ter um efeito significativo na resposta por fluência. Segundo este autor, os fios de um geotêxtil raramente são retilíneos e exatamente na direção da tensão aplicada, mesmo para o caso de geotêxteis tecidos, em que os fios são na sua maioria dobrados em pelo menos uma direção. Assim, a extensão das fibras devido à aplicação de um carregamento em uma direção está correlacionada com a contração na direção perpendicular (Figura 2.10). No caso de geotêxteis não-tecidos, esse fenômeno é ainda mais acentuado, pois os fios constituintes não são retilíneos.

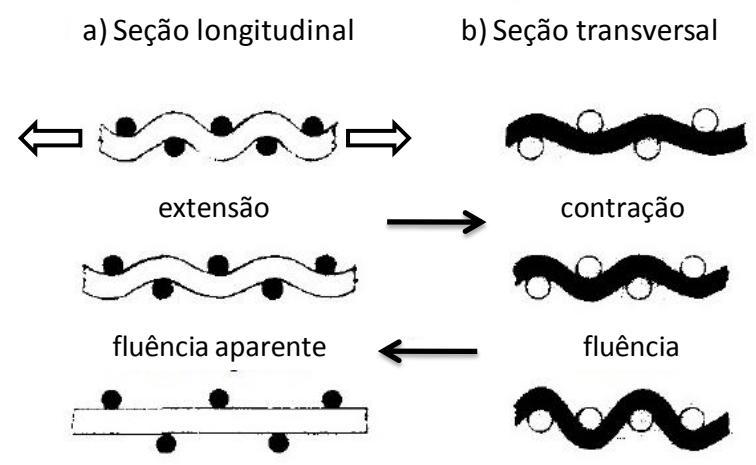

Figura 2.10 - Deformação das fibras de um geotêxtil tecido - (a) Sentido longitudinal à aplicação do carregamento; (b) Sentido transversal à aplicação do carregamento (adaptado de DEN HOEDT, 1986).

Costa (1999) mostrou que, para um mesmo polímero, os geotêxteis não-tecidos formados por filamentos contínuos apresentam maior tendência à fluência quando comparados aos de fibras curtas.

Os principais tipos de polímeros utilizados como matéria-prima dos geossintéticos são: polietileno (PE), polipropileno (PP), poliéster (PET) e poliamida (PA). Esses materiais apresentam duas morfologias típicas, amorfa e cristalina. $\mathrm{O}$ estado amorfo caracteriza-se por uma completa ausência de ordem entre as moléculas, ou seja, cada uma se entrelaça aleatoriamente com a outra. No estado cristalino, ao contrário, as moléculas são orientadas ou 
alinhadas, semelhantes à estrutura de um cristal. Como esses dois estados coexistem e a cristalinidade nunca atinge $100 \%$, os polímeros são em geral tidos como amorfos e semicristalinos (BUENO, 2004). Quanto maior a cristalinidade do polímero, maior a sua rigidez, estabilidade dimensional, resistência química, resistência a abrasão, temperatura de fusão e de transição vítrea. Portanto, o grau de cristalinidade e a porcentagem de zonas amorfas ditam o comportamento das propriedades do polímero (VAN ZANTEN, 1986; DEN HOEDT, 1986). Assim sendo, o comportamento tensão-deformação (curto prazo) é determinado pela deformação das regiões amorfas. Já em caso de carregamento prolongado (fluência) a parte cristalina é a mais importante.

Entre os polímeros utilizados na fabricação de geotêxteis, o polipropileno tem de 70 a $80 \%$ de áreas cristalinas, o polietileno 75 a 85\% e o poliéster 30 a 40\% (DEN HOEDT, 1986). Portanto, os polímeros influenciam de forma marcante o comportamento em fluência. Sobre essa questão, verifica-se que o polietileno (PE) apresenta os mais elevados valores de fluência, seguido pelo polipropileno (PP), poliamida (PA) e poliéster (PET) (DEN HOEDT, 1986; ABRAMENTO, 1995).

A Figura 2.11 ilustra uma comparação entre a fluência de geossintéticos compostos por diferentes polímeros, submetidos a carregamentos de 20 e $60 \%$ da resistência à tração dos materiais, respectivamente. Observa-se que o polietileno (PE) apresenta os maiores valores de deformação por fluência, seguido pelo polipropileno (PP), poliamida (PA) e poliéster (PET). Para o polipropileno são apresentadas faixas de variação. Observa-se que mesmo para o carregamento de $60 \%$ da carga de ruptura, o poliéster e a poliamida sofrem pequenas deformações por fluência.

a)

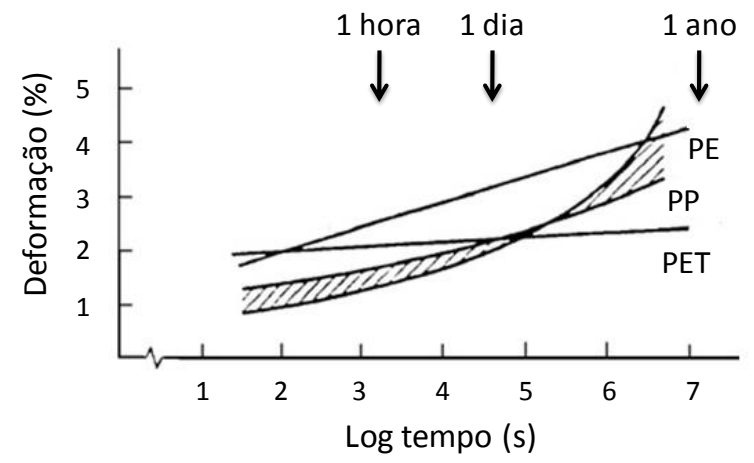

b)

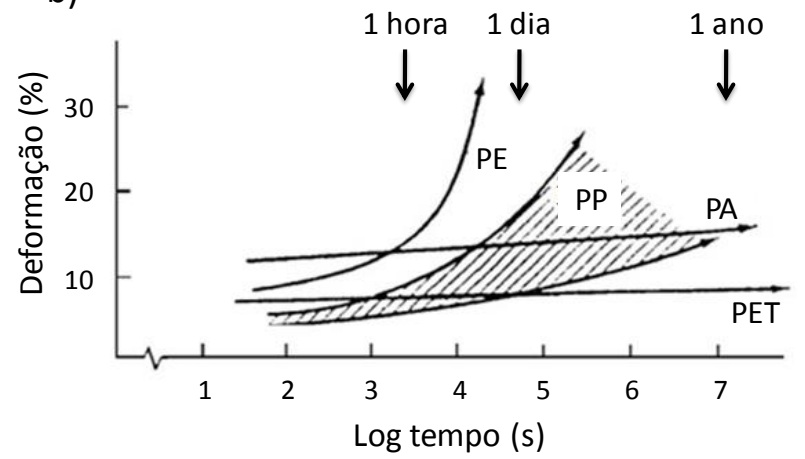

Figura 2.11 - Curvas de fluência para diferentes tipos de polímeros - (a) 20\% da resistência à tração; (b) 60\% da resistência à tração (adaptado de DEN HOEDT, 1986). 
O tipo de geossintético e de polímero apresentam suas próprias interferências no comportamento de fluência do material. Entretanto, como esses efeitos atuam conjuntamente, é difícil quantificar exatamente qual a influência de cada parcela. Den Hoedt (1986) relata que a influência do tipo de polímero em um geotêxtil não-tecido agulhado é pouco significativa, pois a estrutura macroscópica do geossintético é responsável por grande parte das deformações por fluência. Por outro lado, as geogrelhas e os geotêxteis tecidos têm deformações por fluência que dependem mais do tipo de polímero, levando-se em conta que as deformações devido à estrutura macroscópica do material são pouco significativas. Desta forma, não se pode afirmar que um material seja melhor ou pior que outro, o que ocorre, é um produto ser mais adequado a uma situação especifica que o outro (BUENO, 2004).

\subsubsection{Nível de carregamento aplicado}

O nível de carregamento aplicado a um ensaio de fluência é geralmente expresso em função da porcentagem da resistência à tração do material, obtida por ensaios de curta duração (ASTM D 4595 para geotêxteis; ASTM D 6637 para geogrelhas).

Simonini e Gottardi (2003) apresentam a influência do nível de carregamento no comportamento em fluência, para ensaios executados em geogrelha de polipropileno submetidas a carregamentos de 15, 20 e 25\% da resistência à tração do material (Figura 2.12).

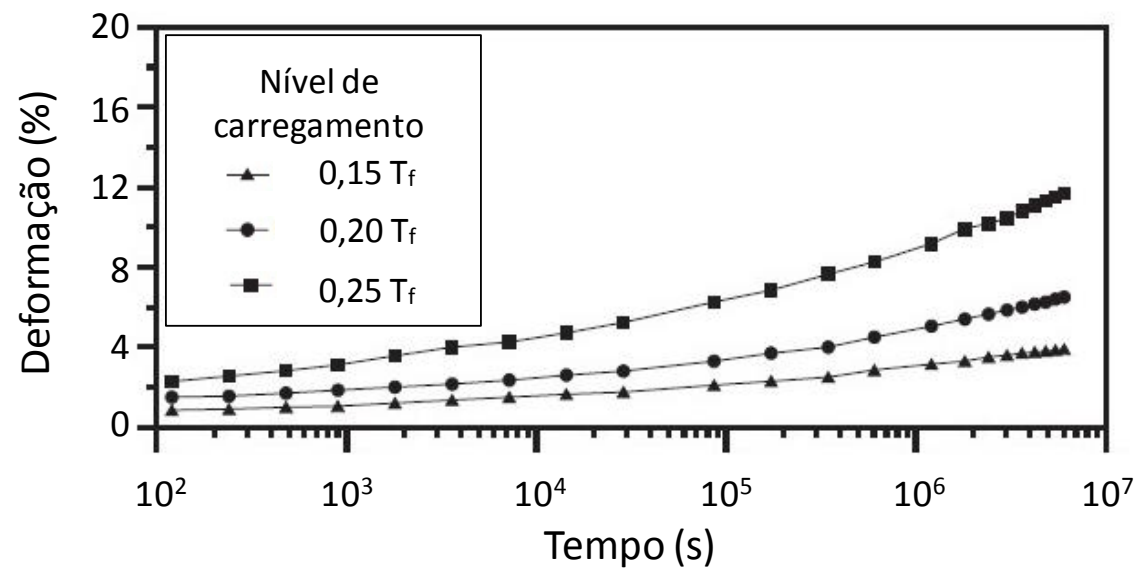

Figura 2.12 - Influência do nível de carregamento no comportamento da fluência em geossintéticos (adaptado de SIMONINI; GOTTARDI, 2003). 


\subsubsection{Velocidade de aplicação do carregamento}

A velocidade de aplicação do carregamento em um ensaio de fluência interfere na taxa de deformação do material com decorrer do tempo. Assim, considerando-se que a deformação por fluência é igual à diferença entre as deformações total e inicial, a redução da velocidade de aplicação do carregamento gera um aumento na deformação inicial, levando a ocorrência de deformações por fluência menores.

Rimoldi e Montanelli (1993) realizaram ensaios que ilustram o comportamento da fluência para diferentes velocidades de carregamento. Esses ensaios foram executados em geogrelhas de PEAD submetidas a uma solicitação de $40 \%$ da resistência à tração (Figura 2.13).

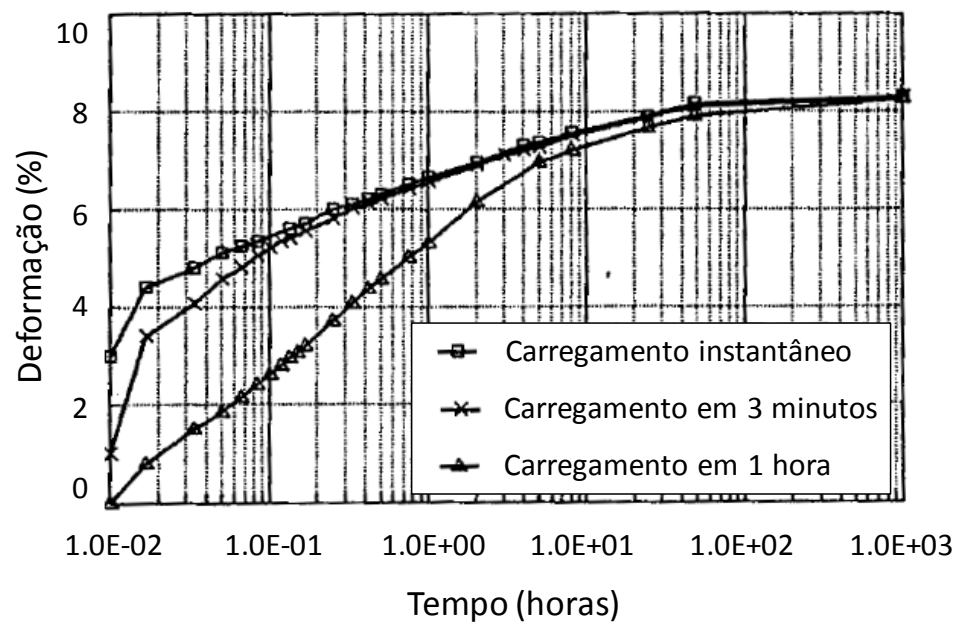

Figura 2.13 - Efeito da velocidade de carregamento na fluência de uma geogrelha de submetida a 40\% da resistência à tração (traduzido de RIMOLDI; MONTANELLI, 1993).

As deformações iniciais maiores para carregamentos mais lentos é explicado pelo comportamento tensão-deformação do material (Figura 2.9b). Deste modo, Andrawes et al. (1984) avaliaram a influência desse fator no comportamento de diversos geossintéticos. Esta análise foi realizada através de ensaios de tração de curta duração. Estes autores destacam que a variação da taxa de carregamento (ou taxa de deformação) influi apenas na deformação devido ao alongamento dos filamentos do geossintético, não sendo relevante nas deformações da macroestrutura do material. Portanto, os geossintéticos com macroestrutura mais homogênea (geotêxteis tecidos), apresentam deformações dependentes da velocidade do carregamento (Figura 2.13). 


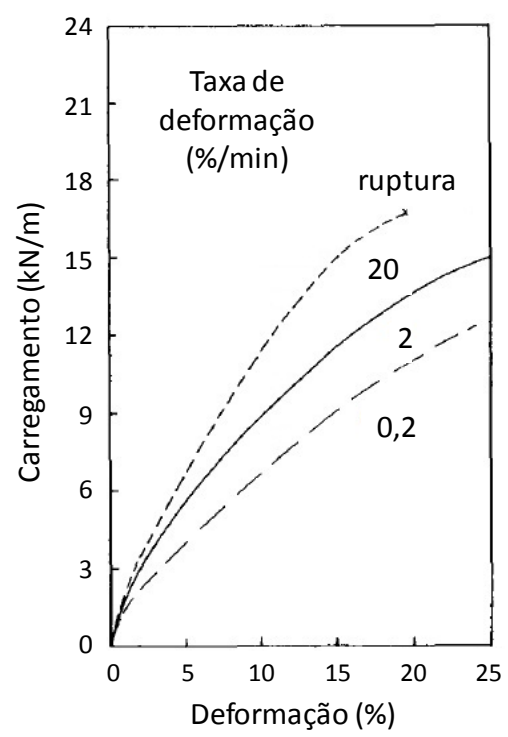

Figura 2.14 - Comportamento de um geotêxtil tecido para diferentes velocidades de carregamento em ensaio de tração (adaptado de ANDRAWES et al., 1984).

\subsubsection{Temperatura}

A elevação da temperatura acelera o fenômeno de deformação por fluência, portanto essa variável deve ser controlada durante os ensaios. Scaffaro et al. (2008) apresentam resultados de ensaios de fluência realizados para diferentes temperatura em uma geomembrana de poliamida (Figura 2.14).

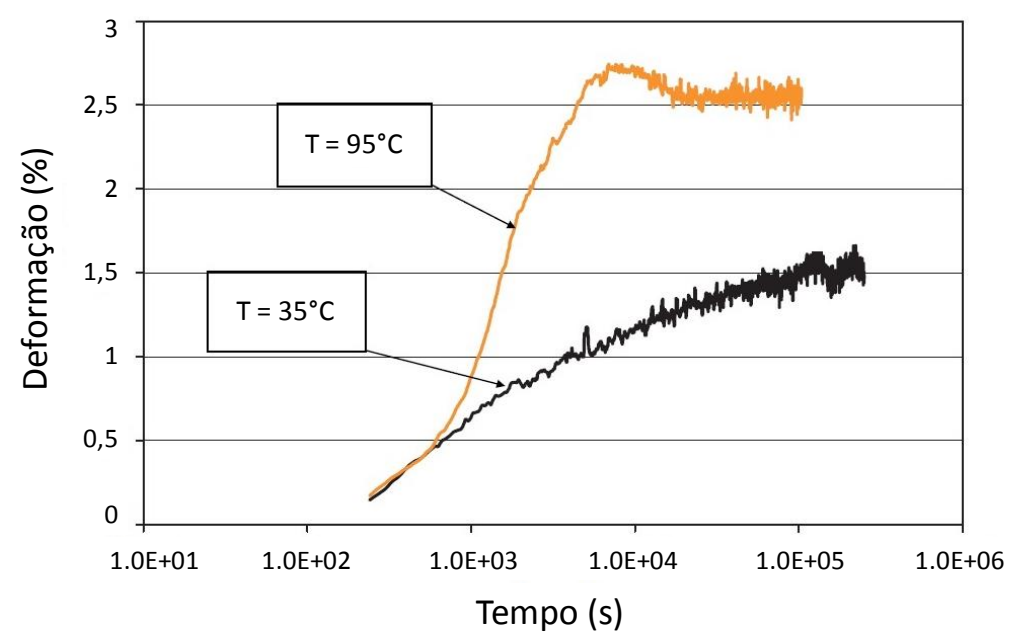

Figura 2.14 - Relação entre a temperatura e deformações por fluência de uma geomembrana de poliamida (adaptado de SCAFFARO et al., 2008). 
O efeito da temperatura depende das características do polímero, tais como, as suas propriedades térmicas. Assim, duas temperaturas importantes regem o comportamento dos geossintéticos quanto aos movimentos moleculares e, portanto, o comportamento viscoelástico dos polímeros. A primeira delas é denominada temperatura de fusão cristalina $\left(\mathrm{T}_{\mathrm{m}}\right) \mathrm{e}$ é caracterizada como aquela a partir da qual o polímero encontra-se em seu estado fundido e não apresenta mais nenhuma região cristalina (quanto maior a cristalinidade de um polímero, maior será o valor de $\left.\mathrm{T}_{\mathrm{m}}\right)$. A segunda, denominada temperatura de transição vítrea $\left(\mathrm{T}_{\mathrm{g}}\right)$ é definida como aquela na qual o polímero passa do estado vítreo (sólido) para o estado de mobilidade, quando se torna essencialmente mais deformável (FERRY, 1980). Desta forma, as deformações por fluência dos polímeros serão mais significativas quando o material for submetido a um carregamento constante em uma temperatura acima do seu valor de $\mathrm{T}_{\mathrm{g}}$ (FRANÇA, 2012).

\subsubsection{Confinamento}

O confinamento é uma variável que deve ser estudada, pois o comportamento tensão-deformação dos geossintéticos submetidos a esse efeito podem ser bastante diferente daquele obtido nos materiais em isolamento (não confinados). Alguns estudos apresentam que as deformações por fluência nesta condição são inferiores àquelas previstas com base em ensaios não confinados (MCGOWN et al., 1982; COSTA, 2004; FRANÇA; BUENO, 2011; FRANÇA, 2012). Deste modo, estes autores sugerem que os projetos baseados em parâmetros obtidos por ensaios não confinados são muito conservadores.

Costa (1999) apresenta uma comparação entre resultados de ensaios de fluência para a condição não confinada e confinada (50 kPa de tensão vertical), realizados em geotêxtil não-tecido agulhado de polipropileno com carregamento de $40 \%$ da resistência à tração. A Figura 2.15 apresenta as curvas de fluência para essas condições de ensaio. 


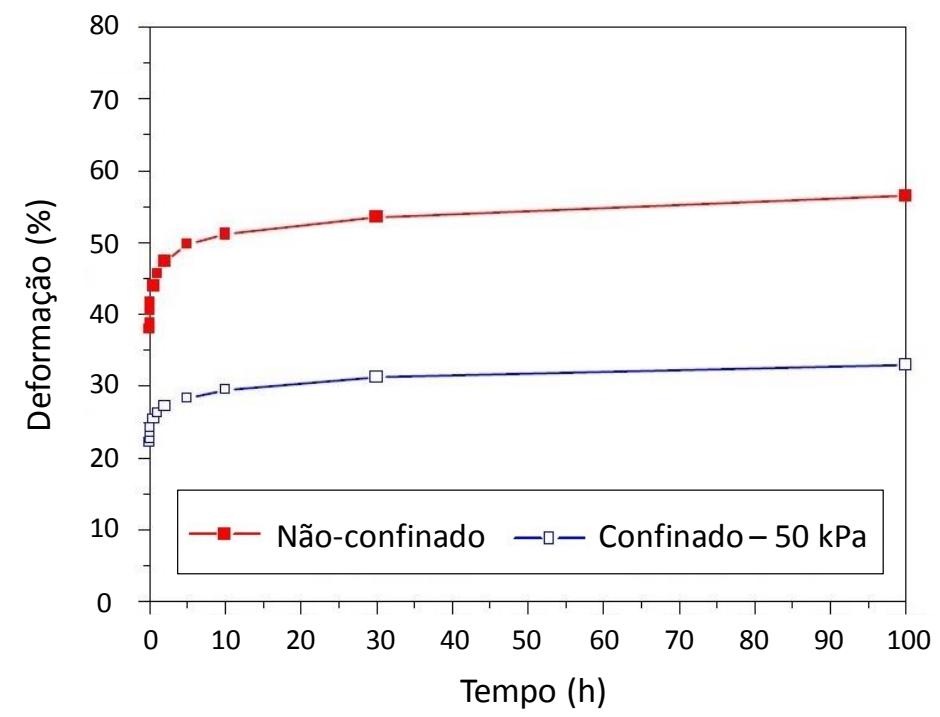

Figura 2.15 - Comparação entre ensaio confinado e não confinado (COSTA, 1999).

Quando um geotêxtil é confinado no solo, esta condição pode reduzir a liberdade estrutural do geossintético, restringindo o movimento entre as fibras, e aumentando o atrito entre as mesmas (COSTA, 1999). Esse efeito é mais significativo em geossintéticos com distribuição aleatória das fibras (geotêxteis não-tecidos), menos significativos nos geotêxteis tecidos e praticamente ausente nas geogrelhas (KOERNER, 2005). Além disso, no confinamento, as partículas de solo penetram a matriz têxtil da manta e promovem uma restrição ao movimento (BUENO; VILAR, 2004).

McGOWN et al. (1982) investigaram o efeito do confinamento na fluência de geotêxteis. Estes autores avaliaram um geotêxtil não-tecido composto por $67 \%$ de polipropileno (PP) e 33\% de polietileno (PE) e um composto por poliéster (PET), representados na Figura 2.16. Observa-se que o confinamento em solo diminuiu as deformações iniciais em ambos os casos e reduz as deformações por fluência nas poliolefinas (PE e PP). Por outro lado, o confinamento em solo não possuiu uma influência significativa na fluência do PET, resultando redução apenas nas deformações iniciais. 

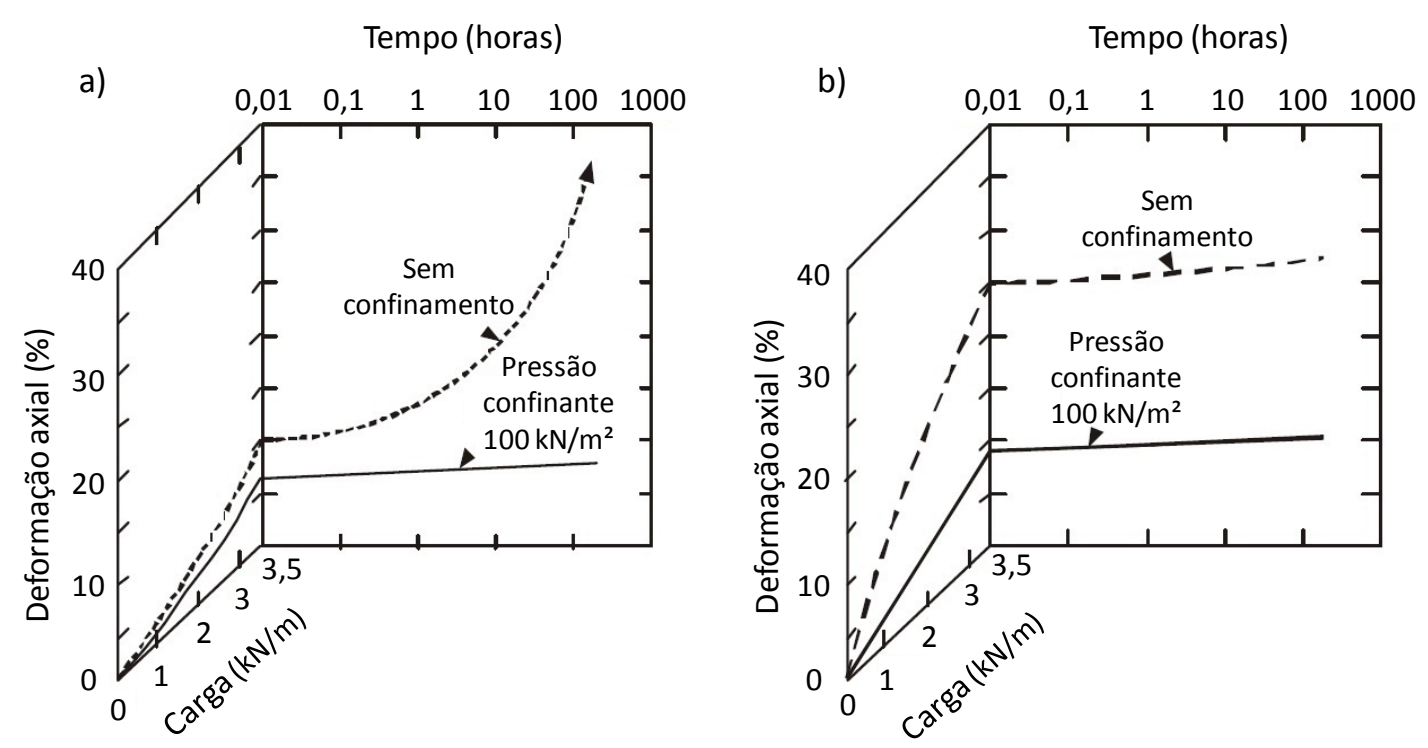

Figura 2.16 - Resultados dos ensaios de fluência de geotêxteis não-tecidos - (a) Termoligado, $33 \%$ PEAD e 67\% PP; (b) Agulhado, 100\% PET (adaptado de MCGOWN et al., 1982).

\subsubsection{Conjunto confinamento e temperatura}

A literatura apresenta vários estudos e resultados sobre ensaios acelerados e ensaios confinados, porém aplicados separadamente. Em um trabalho pioneiro, França (2012) desenvolveu um equipamento capaz de realizar ensaio de fluência confinada e acelerada, simultaneamente em geossintéticos. A Figura 2.17 apresenta os resultados dos ensaios acelerado e confinado-acelerado realizados em um geotêxtil não-tecido de poliéster com filamentos contínuos. Estes ensaios foram conduzidos com temperatura aproximada de $38^{\circ} \mathrm{C}$ e nível de carregamento de $60 \%$ da resistência à tração desse material. $\mathrm{O}$ ensaio confinadoacelerado foi realizado em condição de confinamento em areia seca e com tensão normal de $50 \mathrm{kPa}$. 


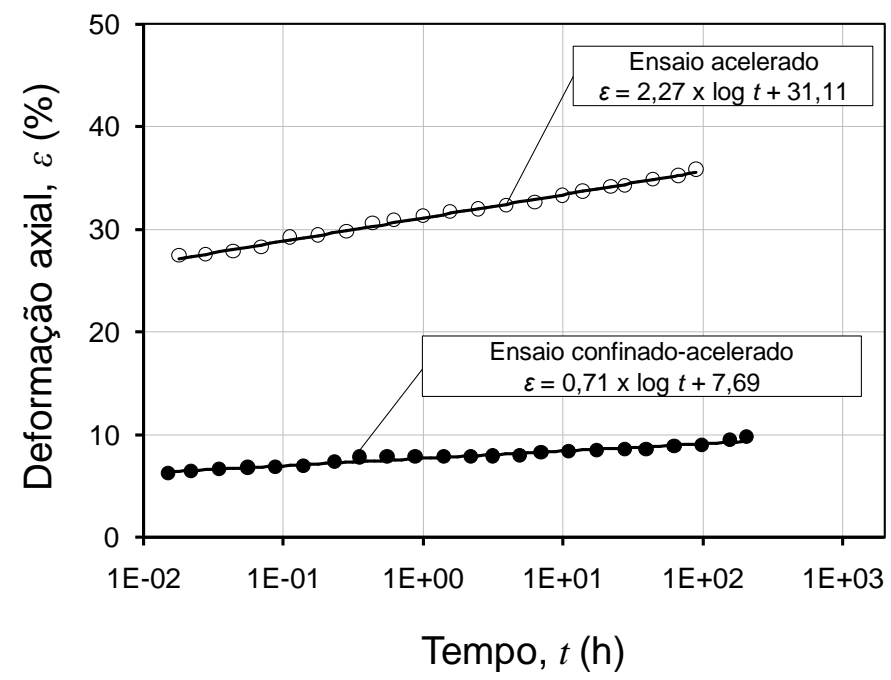

Figura 2.17 - Curvas de fluência dos ensaios acelerado e confinado-acelerado conduzidos em geotêxtil não-tecido de poliéster (FRANÇA et al., 2011).

Esses resultados mostram que o confinamento foi eficaz na redução das deformações por fluência desse geossintético. Desta forma, comparando-se os valores dos coeficientes angulares, observa-se uma redução de aproximadamente $69 \%$ na taxa de deformação por fluência para os ensaios conduzidos em temperatura elevada. Esses resultados são coerentes com o indicado no item 2.3.5, no qual as deformações por fluência dos geotêxteis não-tecidos são dependentes do confinamento. Adicionalmente, observa-se uma redução na deformação inicial do corpo de prova, para o ensaio em condição de confinamento.

Além disso, França e Bueno (2011) avaliaram a influência do confinamento e da temperatura de ensaio no comportamento em deformação por fluência de uma geogrelha de poliéster. Nesta análise, estes autores executaram ensaios convencional, acelerado (temperatura de $45^{\circ} \mathrm{C}$ ), confinado em areia (tensão normal de $50 \mathrm{kPa}$ ) e confinado-acelerado (tensão normal de $50 \mathrm{kPa}$ e temperatura de $45^{\circ} \mathrm{C}$ ). $\mathrm{O}$ nível de carregamento empregado nestes ensaios foi de $50 \%$ da resistência à tração do material. Esta série de ensaios permitiu avaliar a influência separada e conjunta dos parâmetros impostos aos ensaios. Os resultados estão apresentados na Figura 2.18. 

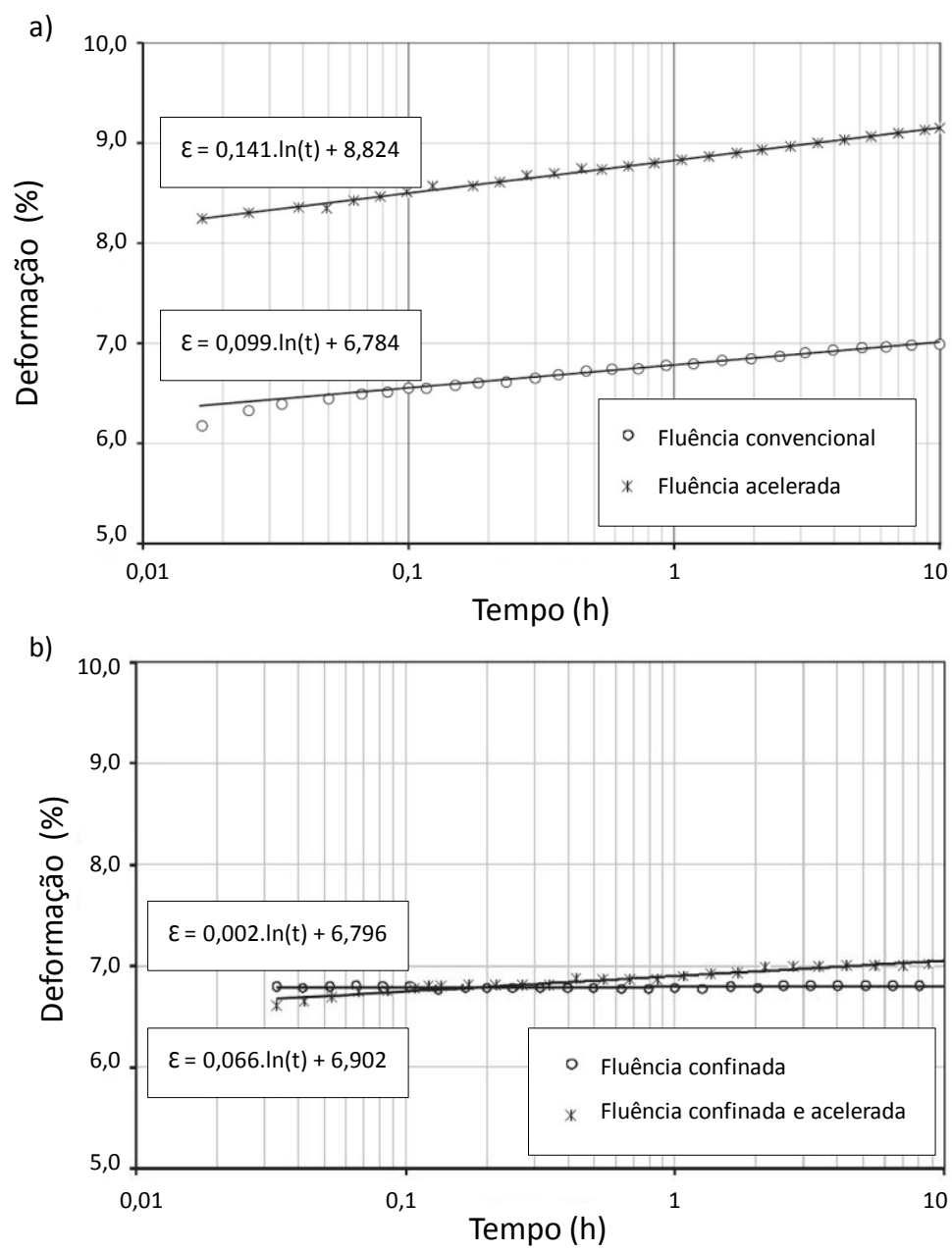

Figura 2.18 - Ensaios de fluência realizados em uma geogrelha de poliéster - (a) Ensaio convencional e acelerado; (b) Ensaio confinado e ensaio confinado e acelerado (adaptado de FRANÇA; BUENO, 2011).

A influência de cada condição imposta aos ensaio pode ser observada por meio da diferença entre as inclinações das retas de ajuste dos pontos de cada ensaio. Desta forma, o valor de 0,002 para o ensaio confinado (Figura 2.18b) é expressivamente menor que 0,099, do ensaio convencional (Figura 2.18a), ou seja, cerca de 2\%. Assim, esses resultados indicam o contrário do que a literatura técnica propõem, ou seja, as deformações por fluência das geogrelhas mostram-se dependentes do confinamento. Por outro lado, para os ensaios apenas confinado e confinado e acelerado, verifica-se que a taxa de deformação por fluência aumenta quando há acréscimo de temperatura (Figura 2.18b), indicando a dependência do aumento de temperatura do ensaio. Desta forma, França e Bueno (2011) sugerem-se que o comportamento em deformação por fluência deva ser avaliado neste tipo de geossintético. 


\subsubsection{Combinação entre diversos tipos de degradação}

Outro fator que pode influenciar as deformações por fluência é a degradação dos materiais por temperatura, luz ultravioleta e umidade, ou a combinação entre eles. Trentini et al. (2006) avaliaram a combinação entre a perda de resistência devido à degradação química em meio alcalino (solução de $\mathrm{Ca}(\mathrm{OH})_{2} \mathrm{com}$ pH igual a 12) e à degradação por fluência. Estes ensaios foram conduzidos em fibras de poliéster. Os resultados dos fatores isolados e em conjunto estão apresentados na Figura 2.19a. Percebe-se que o efeito combinado (soma dos fatores) dos tipos de degradação gera um fator de redução maior que o produto dos efeitos separadamente (Figura 2.19b).
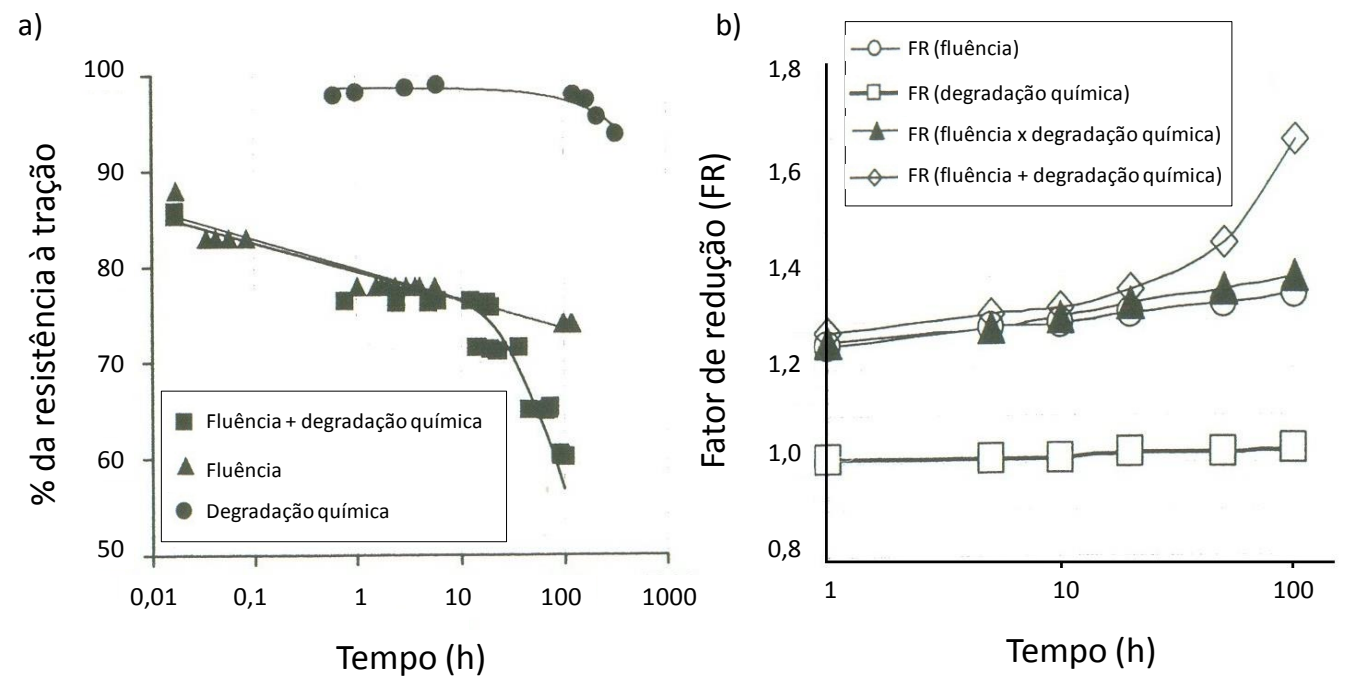

Figura 2.19 - Combinação entre degradação química e fluência de fibras de poliéster - (a) Perda de resistência; (b) Fatores de redução (adaptado de TRENTINI et al., 2006).

\subsection{Ensaios para determinação da fluência em geossintéticos}

A seleção dos geossintéticos para atender às exigências construtivas deve se basear em propriedades de engenharia que traduzam as condições técnicas a que serão submetidos quando em serviço (BUENO; VILAR, 2004). Essas propriedades são determinadas a partir de ensaios de campo ou, mais comumente, de laboratório. Os ensaios, para serem realistas, devem reproduzir os aspectos e as condições do meio em que serão inseridos em obra. Desta forma, os itens a seguir apresentam os diversos métodos de ensaios utilizados na determinação do comportamento em fluência dos geossintéticos. 


\subsubsection{Ensaio convencional}

Grande parte dos dados existentes sobre a fluência dos geossintéticos provém de ensaios convencionais de laboratório, nos quais, o material é estudado isoladamente (KAMIJI, 2006). Nestes ensaios, os corpos de prova, geralmente de $200 \mathrm{~mm}$ de largura e $200 \mathrm{~mm}$ de comprimento, são submetidos a carregamentos constantes que correspondem a uma parcela de sua resistência à tração, procedendo-se o registro do alongamento do corpo de prova em tempos pré-estabelecidos. Este ensaio é normalizado por diversas entidades (NBR 15.226; ASTM D 5262; ISO 13.431) e deve ser executado sob condições controladas de temperatura e umidade relativa do ar.

A Figura 2.20 apresenta um modelo do equipamento utilizado para ensaios convencionais de fluência. Esse método é relativamente simples e, apesar de algumas diferenças, envolvem basicamente três divisões: sistema de ancoragem, sistema para acompanhamento das deformações e sistema de aplicação de carga (COSTA, 1999). A fixação do geotêxtil é realizada através de garras que devem possuir, no mínimo, a mesma largura do corpo de prova e impedir o seu deslizamento. Um conjunto de pesos livres submete a amostra a um esforço de tração constante, ao passo que as deformações são obtidas ao longo do tempo.

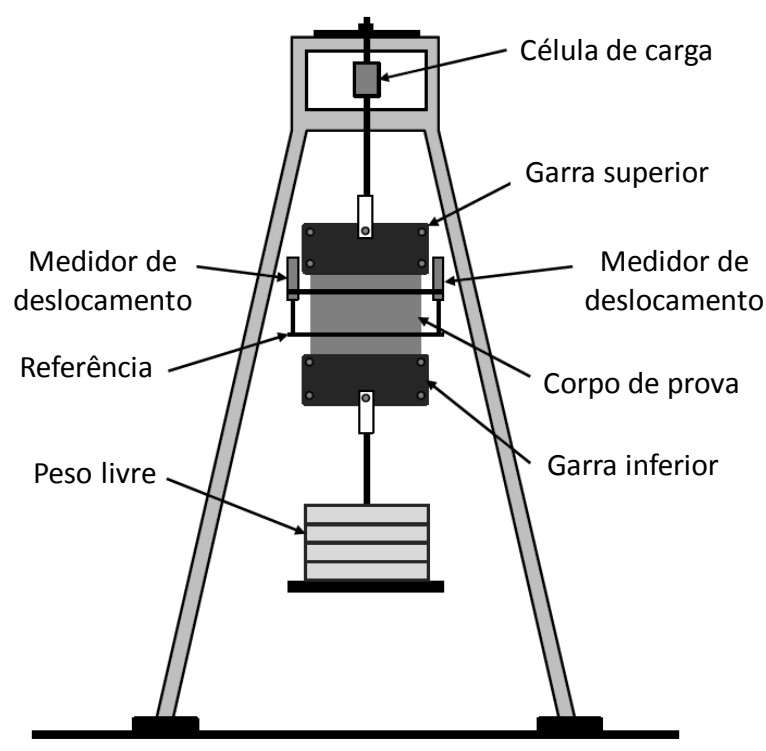

Figura 2.20 - Equipamento utilizado na realização dos ensaios de fluência convencional (adaptado de ASTM D 5262, 2007). 
Duas abordagens diferentes de ensaio podem ser adotadas, dependendo do aspecto a ser investigado. Para caracterização do comportamento em deformação por fluência do geossintético ao longo do tempo, carregamentos entre $10 \%$ e $60 \%$ da resistência à tração do material são geralmente aplicadas, procedendo-se o registro das deformações nos tempos préestabelecidos. As normas recomendam que pelo menos quatro níveis de carregamento sejam aplicados em diferentes corpos de prova e que esses ensaios durem entre 1.000 e 10.000 horas. Caso a ruptura por fluência seja o interesse, aplicam-se carregamentos entre $60 \%$ e $90 \%$ da resistência à tração do material. Para este caso, procede-se com o registro do tempo de ruptura correspondente. As normas recomendam a utilização de três corpos de prova para cada nível de carregamento utilizado. A Figura 2.8 ilustra o procedimento para obtenção da curva de ruptura por fluência, que na maioria das vezes, apresenta um comportamento linear (MÜLLER-ROCHHOLZ, 1998).

O principal problema associado ao ensaio convencional é o tempo demandado em sua execução e para que se obtenha uma resposta significativa (MATICHARD et al., 1990). Além disso, outro problema refere-se à ausência da caracterização quanto ao comportamento da interação solo-geossintético. Considerando-se que esse fenômeno está presente na maioria das obras onde os geossintéticos são empregados, a definição desses parâmetros se torna necessário (COSTA, 2004; KAMIJI, 2006; FRANÇA; BUENO, 2011). Desta forma, outras configurações foram elaboradas a fim de investigar esse efeito sobre o comportamento em fluência dos geossintéticos. Além disso, metodologias foram propostas para acelerar a determinação do comportamento em fluência dos geossintéticos.

\subsubsection{Ensaio acelerado}

Conforme apresentado anteriormente, um dos maiores empecilhos relacionados aos ensaios convencionais de fluência é o tempo necessário para a sua execução. No entanto, devido ao comportamento dos geossintéticos diante ao aumento de temperatura (descrito no item 2.3.4), um recurso para mitigar esse inconveniente é a utilização de temperaturas elevadas durante a execução do ensaio, juntamente com o emprego de ferramentas para tratamentos dos dados (ALLEN, 1991). Assim, com os resultados de diversos ensaios em diferentes temperaturas, as curvas obtidas em cada um deles podem ser transladadas de forma a se sobreporem e permitirem a obtenção de uma curva única (FARRAG, 1998), que é 
denominada de curva mestra de fluência (Figura 2.21).

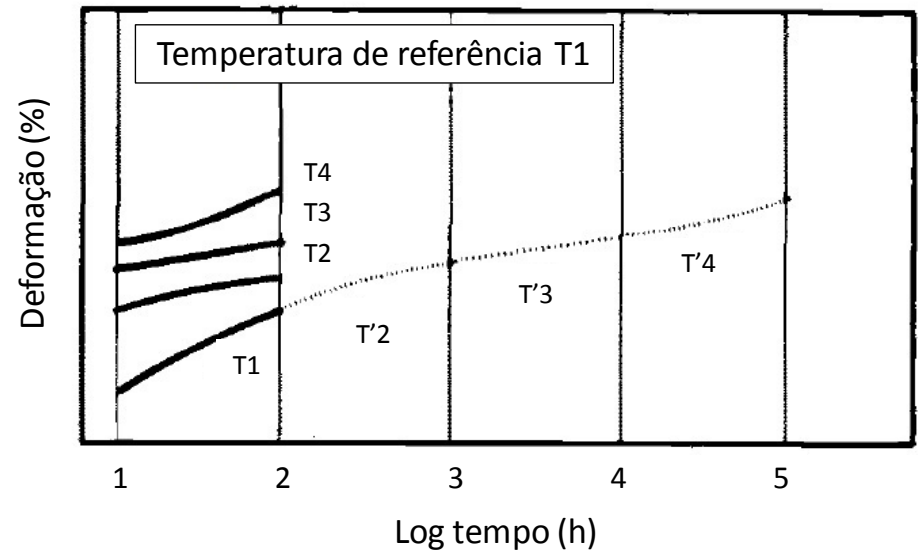

Figura 2.21 - Translação horizontal dos resultados de ensaios de fluência conduzidos em temperaturas diferentes com o mesmo nível de carregamento (adaptado de FARRAG, 1998).

O processo de translação das curvas de fluência é embasado conceitualmente no princípio denominado de superposição tempo-temperatura (STT). Esse princípio sugere que os processos físicos causados por carregamentos mecânicos (deformações), podem ser acelerados pela elevação de temperatura (THORNTON et al., 1997). Essa relação é descrita pela Equação de Arrhenius, que é apresentada na Equação 5 (KOERNER et al., 1992).

$$
R_{r}=A \cdot e^{\left(\frac{-E}{R \cdot T}\right)}
$$

onde $R_{r}$ é a taxa de ocorrência do fenômeno estudado; $A$ uma constante que depende do material e do fenômeno envolvido; $E$ a energia de ativação, em $\mathrm{J} / \mathrm{mol} ; R$ a constante universal dos gases (8,314 J/K.mol); $T$ a temperatura absoluta, em K.

Utilizando essa equação no estudo da fluência em geossintéticos, $R_{r}$ é substituído pela taxa de deformação por fluência $(\dot{\varepsilon})$. Assim, a equação relaciona duas taxas de deformação por fluência em duas temperaturas distintas, conforme apresentado na Equação 6 (BARAS, 2001). Assume-se que o comportamento viscoelástico dos geossintéticos e a energia de ativação são constantes para os ensaios conduzidos em temperaturas elevadas (ZORNBERG et al., 2004).

$$
\ln \left(\frac{\dot{\varepsilon_{1}}}{\dot{\varepsilon_{2}}}\right)=\frac{E}{R} \cdot\left(\frac{1}{T_{2}}-\frac{1}{T_{1}}\right)
$$

Essa equação retrata muito bem o comportamento de gases, mas no caso de materiais em estado sólido (geossintéticos), apresenta algumas limitações devido as 
dificuldades de determinação da energia de ativação, uma vez que seu valor não é constante ao longo dos ensaios (BARAS, 2001).

Outro procedimento foi elaborado por Williams, Landel e Ferry (1955) e introduz o conceito de fator de translação (do inglês, shift factor). Esse fator é definido como a razão entre o tempo necessário para que um processo viscoelástico ocorra em uma temperatura qualquer e o tempo necessário para que o mesmo processo ocorra em uma temperatura de referência (THORNTON et al., 1997). Neste processo, as curvas de fluência obtidas para temperatura superiores a um valor de referência são transladadas ao longo do eixo de tempo de forma a se obter uma única curva, a curva mestra (BARAS, 2001). Esse fator é expresso pela Equação 7.

$$
a_{T}=\frac{t_{i}}{t_{R}}
$$

onde $a_{T}$ é o fator de translação; $t_{i}$ o tempo para que o processo ocorra na temperatura $T$ (elevada) e $t_{R}$ o tempo para que o processo ocorra na temperatura de referência (por exemplo, temperatura ambiente).

O fator de translação pode assumir diferentes valores, determinados em função da diferença entre a temperatura de ensaios e de referência (THORNTON et al., 1997). A Figura 2.22 ilustra uma relação entre o fator de translação e a temperatura (FARRAG, 1998).

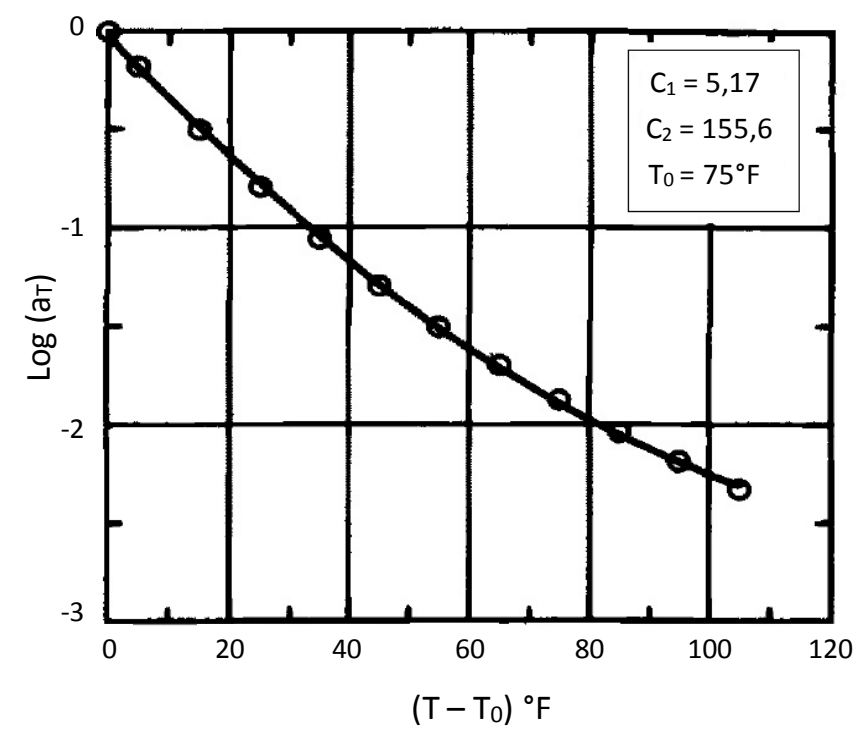

Figura 2.22 - Fatores de translação pela equação de WLF (adaptado de FARRAG, 1998). 
Esse fator é obtido empiricamente e descrito pela Equação WLF (Equação 8).

$$
\log \left(a_{T}\right)=\frac{-C_{1} \cdot\left(T-T_{0}\right)}{C_{2}+T-T_{0}}
$$

onde $C_{1}$ e $C_{2}$ são constantes empíricas que dependem do tipo de polímero no qual o geossintético foi fabricado, da temperatura de transição vítrea $\left(\mathrm{T}_{\mathrm{g}}\right)$ desse polímero e da temperatura de referência. Como valores típicos utilizam-se 17,4 e 51,6 para $C_{1}$ e $C_{2}$, respectivamente (FARRAG, 1998).

Empregando-se a abordagem sugerida por Zornberg et al. (2004), onde o principal parâmetro para avaliação do comportamento em deformação por fluência é o índice de fluência $\left(\mathrm{T}_{\alpha}\right)$, outra relação para a determinação do fator de translação pode ser aplicada (Equação 9) (FRANÇA, 2012).

$$
a_{T}=10^{\left(\log \frac{1}{T_{\alpha, i}}-\log \frac{1}{T_{\alpha, R}}\right)}
$$

onde $a_{T}$ é o fator de translação; $T_{\alpha, i}$ é o índice de fluência para a temperatura $T$ (elevada) e $T_{\alpha, R}$ o índice de fluência para a temperatura de referência (por exemplo, temperatura ambiente).

Para execução do ensaio acelerado utilizando o método convencional, são realizados vários ensaios de fluência em corpos de provas distintos sob mesmo carregamento e em diferentes temperaturas. Os equipamentos utilizados para este tipo de ensaio podem ser os mesmos utilizados para a fluência convencional, acrescentando-se um ambiente de temperatura controlada (FARRAG; SHIRAZI, 1997). A desvantagem desse procedimento é a utilização de vários corpos de prova, o que aumenta a possibilidade de variabilidade nos resultados (COSTANZI, 2003).

Outro procedimento, que foi idealizado por Thornton et al. (1998) denomina-se Stepped Isothermal Method (SIM), contando com norma Americana (ASTM D 6992). Diversos autores publicaram estudos com ensaios acelerados de fluência nos quais essa metodologia foi aplicada (BARAS, 2001; THORNTON; BAKER, 2002; BARAS et al., 2002; COSTANZI, 2003; COSTANZI et al., 2003; ZORNBERG et al., 2004). Por necessitar apenas de um corpo de prova, esse método elimina o problema devido à variabilidade dos corpos de prova, bem como acelera a geração da curva de fluência.

A metodologia SIM se baseia no mesmo princípio de superposição tempotemperatura (STT) para a caracterização das propriedades viscoelásticas de materiais poliméricos (ZORNBERG et al., 2004). Além disso, o princípio da superposição de 
Boltzmann indica que a deformação por fluência é função do histórico de carregamento aplicado e que cada novo carregamento é tratado com um evento independente. Assim, a resposta total de fluência é a soma das respostas individuais de cada evento independente (THORNTON et al., 1998). A norma ASTM D 6992 recomenda que os incrementos de temperatura sejam atingidos em até quatro minutos, a fim de manter o estado físico do corpo de prova.

A Figura 2.23 ilustra a geração da curva mestra de fluência a partir dos resultados de ensaios pelo método SIM. Esse ensaio é inicialmente conduzido como um ensaio convencional de fluência, em temperatura ambiente. Após um período pré-determinado, procede-se um incremento de temperatura.

Para a construção da curva mestra, realiza-se a modificação da escala de tempo dos dados em cada temperatura do ensaio (Figura 2.23b). É necessário aplicar correções ao tempo de ensaio, fazendo com que a inclinação final da curva de fluência em escala logarítmica obtida em uma temperatura seja idêntica à inclinação inicial da curva de fluência obtida na temperatura subsequente. O Procedimento é empírico, mas consistente com as equações de Arrhenius e WLF (ZORNBERG et al., 2004). Uma vez que o processo físico em análise é a taxa de deformação por fluência dos corpos de prova, que são representados pela inclinação das curvas de fluência, os dados obtidos em cada temperatura são modificados empiricamente para corresponderem àqueles encontrados na temperatura de referência (COSTANZI et al., 2003). O resultado desse processo é ilustrado na Figura 2.23b. Em seguida, é feita a translação dos segmentos de maneira a se sobreporem e produzir a curva mestra de fluência do geossintético, para um dado nível de carregamento (Figura 2.23c). 

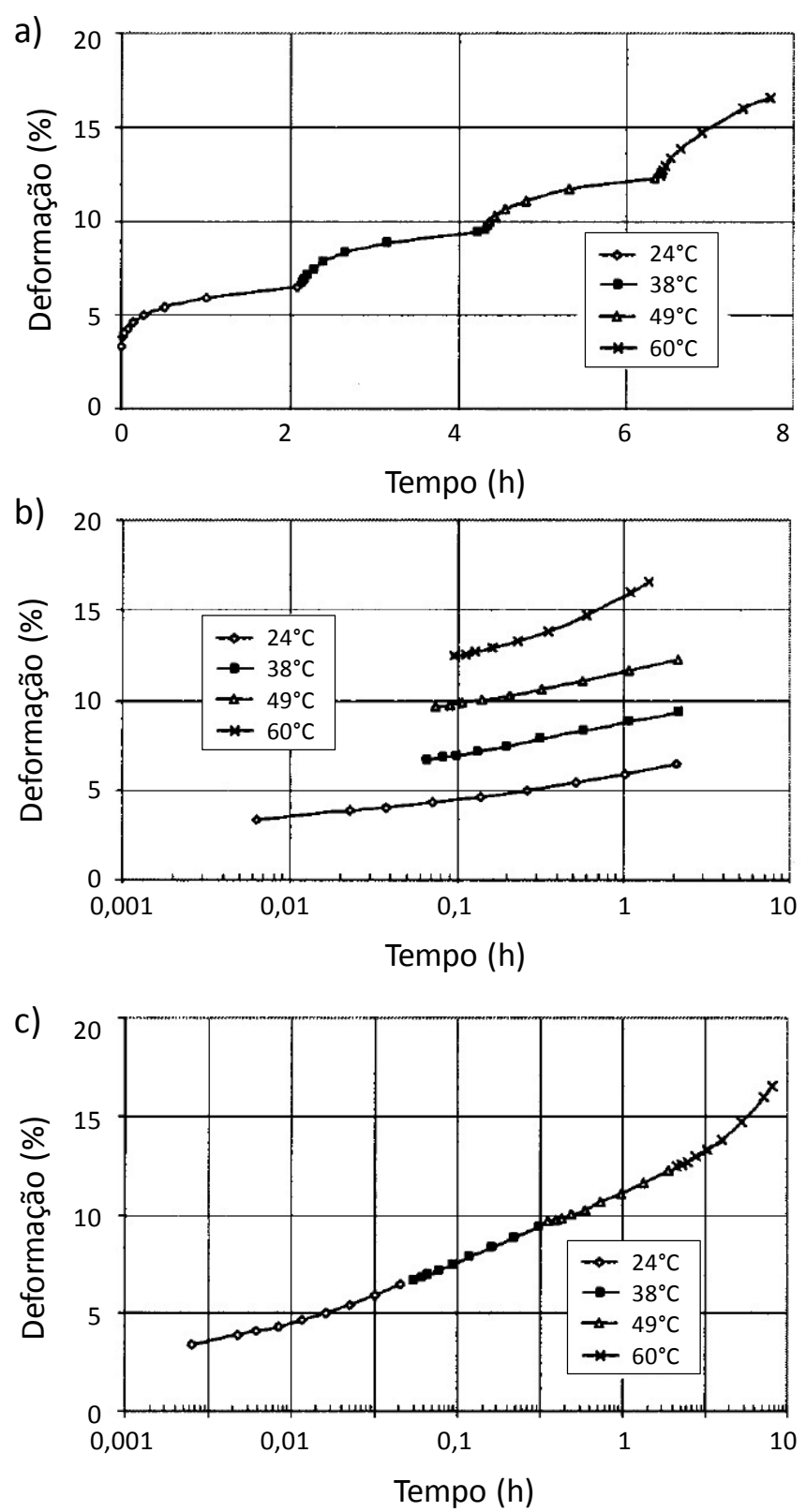

Figura 2.23 - Obtenção da curva mestra pelo método SIM - (a) Dados em escala natural; (b)

Dados em escala logarítmica; (c) Curva mestra (adaptado de ZORNBERG et al., 2004).

\subsubsection{Confinado}

O outro empecilho relacionado à execução dos ensaios convencionais de fluência diz respeito à ausência do efeito de confinamento para caracterização do comportamento em fluência dos geossintéticos. Conforme apresentado no item 2.3.5, os geossintéticos podem apresentar deformações dependentes desse efeito. Desta forma, essa deficiência foi 
solucionada através dos ensaios capazes de simular as condições de confinamento de um geossintético em campo. Diversos estudos empregaram equipamentos especiais para verificar o desempenho dos geossintéticos neste âmbito (COSTA, 1999; COSTA, 2004; KAMIJI et al., 2008; BECKER; NUNES, 2002; FRANÇA, 2012). Estes autores detalham os diversos equipamentos utilizados para a realização de ensaios confinados de fluência. Apesar de possuírem um propósito comum, considera-se a existência de duas linhas distintas de ensaios: aqueles nos quais a carga é aplicada diretamente ao geossintético e aqueles nos quais uma tensão confinante é aplicada ao solo circundante, gerando tensões no corpo de prova, desenvolvidas pela interação solo-geossintético.

Para o caso dos ensaios onde a carga é aplicada diretamente ao geossintético, os equipamentos utilizados são constituídos pelos mesmos componentes do convencional, acrescentando-se um sistema para aplicação de confinamento (Figura 2.24). Nesta modalidade de ensaio, o geossintético é tracionado aplicando-se uma carga constante (F) diretamente ao corpo de prova, na maioria das vezes, através de pesos livres. Além da força de tração, uma tensão confinante é aplicada ao geossintético, que geralmente é inserido entre duas camadas de solo.

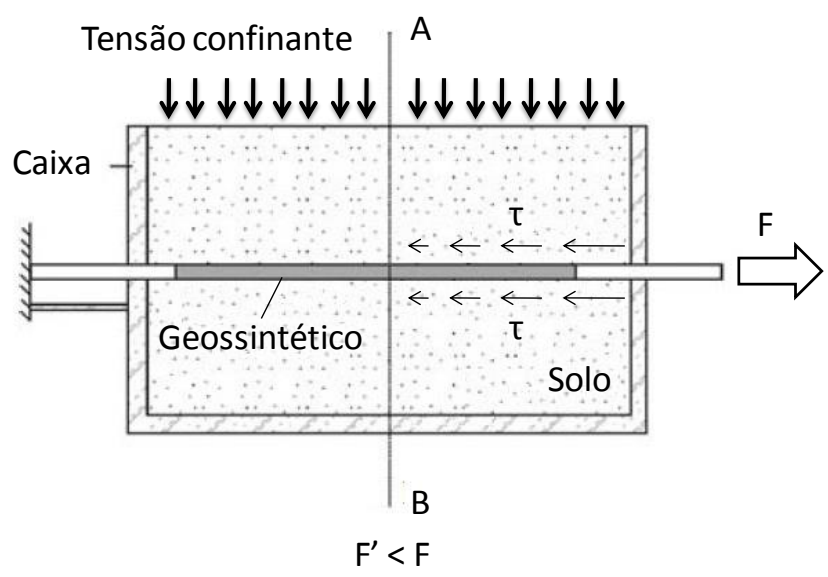

Figura 2.24 - Modelo de ensaios no qual a carga é aplicada diretamente ao geossintético (adaptado de COSTA, 2004).

Para Wu (1991), o principal aspecto negativo da aplicação desse modelo é a existência de movimento relativo entre o solo confinante e o geossintético, provocando forças de atrito na interface. Esse processo gera dois mecanismos distintos: ação do confinamento e ação de forças de atrito e/ou de adesão ao longo da interface. 
A Figura 2.24 ilustra um possível efeito das forças de atrito e/ou adesão. Caso seja aplicada uma solicitação (F) tracionando o geossintético, o movimento relativo sologeossintético, ocasionado pela deformação do mesmo, provocará o aparecimento de tensões cisalhantes $(\tau)$. Com o desenvolvimento dessas tensões, o corpo de prova fica submetido a solicitações diferentes ao longo de seu comprimento, sendo inferiores àquela que foi aplicada (F). Assim, a solicitação (F') que atua no centro do corpo de prova (corte $A B$ ) é inferior à solicitação (F) aplicada na extremidade.

Esse modelo de ensaio foi estudado pioneiramente por McGown et al. (1982). Estes autores desenvolveram o primeiro equipamento para ensaios de fluência confinada, que serviu de base para o desenvolvimento de muitos outros construídos na sequência. Um esquema do ensaio pode ser visto na Figura 2.25. Nele, o sistema de confinamento é constituído por duas caixas metálicas, onde é inserida uma bolsa de ar pressurizada que, ao ser inflada, pressiona o solo que é colocado entre ela e o corpo de prova de geossintético. Alguns de seus resultados foram apresentados na Figura 2.16 (efeito do confinamento). McGown et al. (1982) relatam que apesar do desempenho satisfatório do equipamento, alguns problemas foram encontrados, tais como, a dificuldade de montagem do ensaio e a variação da força aplicada ao longo do geossintético (devido ao posicionamento vertical do corpo de prova).

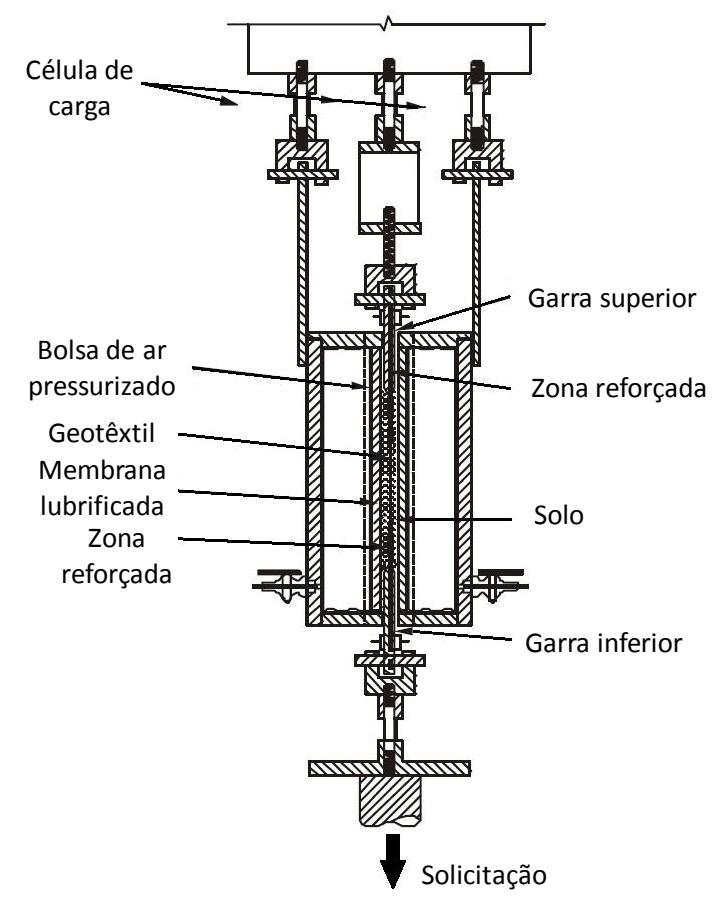

Figura 2.25 - Equipamento para ensaio de fluência confinada em geotêxteis (adaptado de MCGOWN et al., 1982). 
Por outro lado, a Figura 2.26 apresenta um esquema da segunda configuração de equipamento empregado para verificar o comportamento dos geossintéticos sob confinamento. Esse aparato consiste da aplicação de um carregamento vertical constante no topo da camada de solo que, ao se deformar, traciona o geossintético. Destaca-se, que o processo de solicitação do geossintético é bem mais condizente com as condições presentes nas estruturas de solo reforçado, já que o solo solicita o material (COSTA, 2004).

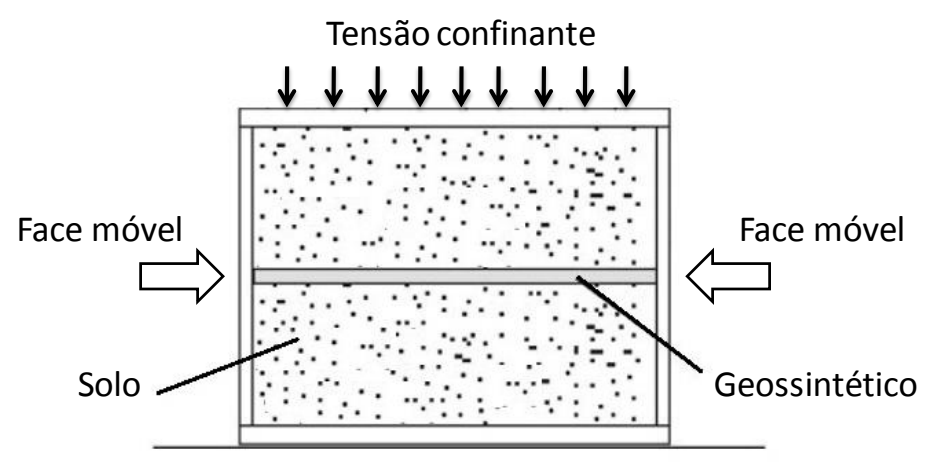

Figura 2.26 - Modelo de ensaios no qual o solo solicita o geossintético (adaptado de COSTA, 2004).

Mesmo sendo a configuração que mais se aproxima das condições reais de campo, vale ressaltar algumas dificuldades, como por exemplo, a taxa de deformação (ou taxa de carregamento). Desta forma, os ensaios confinados de fluência conduzidos neste equipamento resultam em taxas de aplicação de carregamento pequenas, prejudicando a comparação com os resultados dos ensaios convencionais de fluência (verificação do efeito do confinamento).

\subsubsection{Confinado e acelerado}

Visando solucionar ambos os empecilhos relacionados à execução dos ensaios convencionais de fluência em geossintéticos (tempo demandado e ausência do confinamento em solo), França (2012) desenvolveu um equipamento capaz de realizar ensaios de fluência simultaneamente, confinados e acelerados em geossintéticos, denominado de ensaio confinado-acelerado (resultados discutidos no item 2.3.6). A Figura 2.27 apresenta um esquema desse equipamento, que é composto basicamente por cinco sistemas: aplicação do carregamento, medição do alongamento do corpo de prova, reprodução do confinamento do 
solo, elevação da temperatura de ensaio e aquisição dos dados.

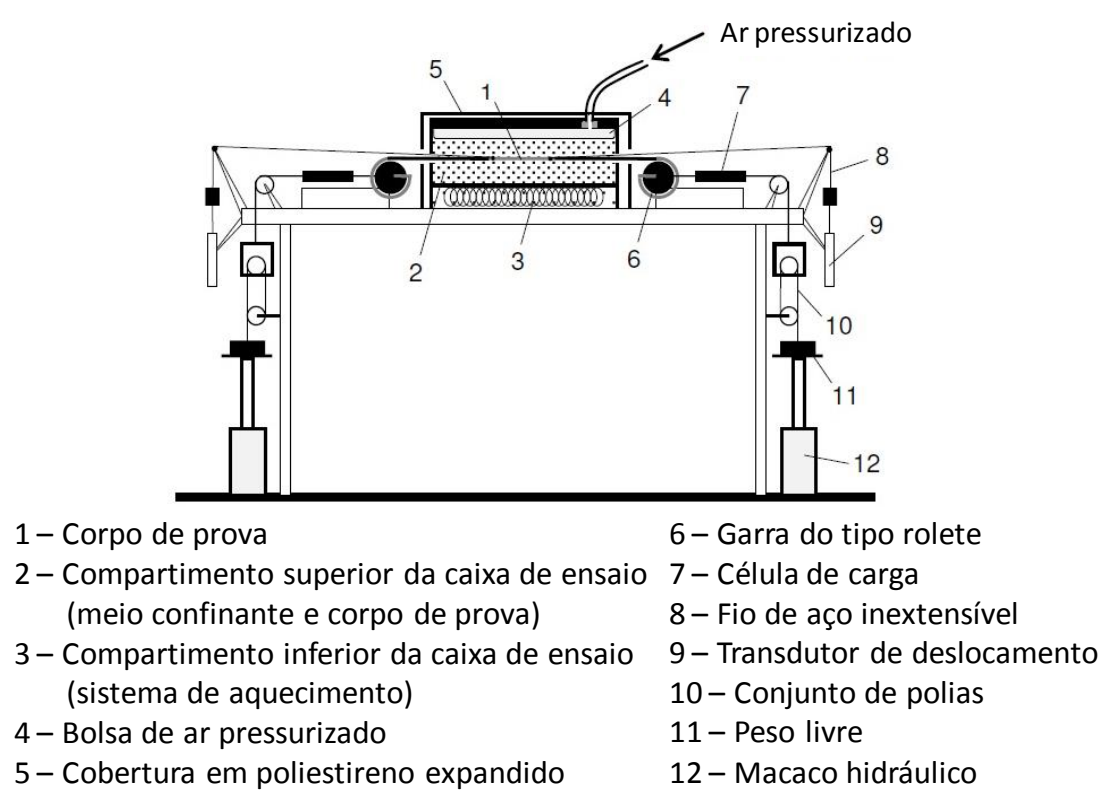

Figura 2.27 - Equipamento utilizado para ensaios confinado e acelerado em geossintéticos

(FRANÇA et al., 2011).

Este consiste de um aparato onde o corpo de prova é posicionado na parte superior de uma câmara, que pode ou não ser preenchida com o meio confinante para a reprodução do confinamento do solo. Observa-se que o corpo de prova apresenta regiões reforçadas e lubrificadas, a fim de aumentar a sua rigidez e diminuir o atrito interface solo-geossintético, respectivamente. Uma bolsa de ar pressurizado é utilizada sobre o solo, permitindo a aplicação de uma tensão vertical sobre o mesmo. O sistema de aquecimento, localizado no compartimento inferior da câmara de ensaio, conta com resistências elétricas para obtenção da temperatura desejada. $\mathrm{O}$ corpo de prova é fixado em garras do tipo rolete, que são conectadas ao sistema de carregamento, composto por conjunto de polias e pesos livres. $\mathrm{O}$ alongamento do material é medido durante o desenvolvimento do ensaio.

Segundo França (2012), uma das dificuldades encontradas na utilização desse equipamento foi relacionada ao atrito gerado na interface geossintético-solo. No entanto, este problema foi solucionado com o posicionamento de uma geomembrana de PEAD acima e abaixo do corpo de prova, além da aplicação de um lubrificante entre as geomembranas e as regiões reforçadas dos corpos de prova.

Os resultados apresentados por França e Bueno (2011) mostraram que este 
equipamento é capaz de executar ensaios de fluência tanto em isolamento (não confinado) quanto confinados em solo (Figura 2.18). Além disso, estes autores citam que é possível a realização de quatro diferentes tipos de ensaios de fluência em geossintéticos empregando esse equipamento (convencional, confinado, acelerado e conjuntamente confinado e acelerado).

\subsection{Importância e aplicação da fluência em estruturas de solo reforçado}

Cada vez mais se utilizam geossintéticos em obras de engenharia civil, sendo reforço de solos uma das principais aplicações. Esse crescimento tem por base o seu excelente desempenho, versatilidade, fácil emprego, facilidade de transporte e, principalmente, ao baixo custo quando comparada às soluções tradicionais (SAYÃO et al., 2004). Christopher et al. (1990) citam que as economias geradas por soluções em solo reforçado atingem de 10 a 50\% do custo final da obra.

No entanto, para os projetos de solos reforçados, devido às incertezas com relação aos parâmetros do material, adota-se a definição da resistência admissível dos geossintéticos através do uso de fatores de redução aplicados à resistência à tração do material (VERTEMATTI, 2004; KOERNER, 2005). Essa relação é expressa pela Equação 10, em que os fatores de redução refletem os parâmetros que influenciam na resistência desses materiais (danos de instalação, degradação química e biológica, fluência, incertezas na determinação de parâmetros) e podem ser determinados a partir de ensaios ou de referências na literatura (VERTEMATTI, 2004; KOERNER, 2005). A Tabela 2.1 apresenta os valores de fator de redução sugeridos por Koerner (2005) a serem aplicados em geotêxteis empregados no projeto de diferentes estruturas.

$$
T_{a d m}=\frac{T_{u l t}}{F R_{D I} \cdot F R_{F} \cdot F R_{D Q} \cdot F R_{D B} \cdot f_{m}}
$$

onde $T_{a d m}$ é a resistência à tração admissível do geossintético; $T_{u l t}$ é a resistência à tração do geossintético, obtida em ensaios de tração (NBR 12.824; ASTM D 4595; ASTM D 6637); $F R_{D I}$ é o fator de redução devido aos danos de instalação; $F R_{F}$ é o fator de redução devido à fluência; $F R_{D Q}$ é o fator de redução devido à degradação química; $F R_{D B}$ é o fator de redução devido à degradação biológica; $f_{m}$ o fator de redução devido a incertezas estatísticas da resistência do geossintético. 
Tabela 2.1 - Fatores de redução sugeridos para geotêxteis (KOERNER, 2005).

\begin{tabular}{lcccc}
\hline \multicolumn{1}{c}{ Tipo de obra } & $\begin{array}{c}\text { Danos na } \\
\text { instalação }\end{array}$ & Fluência* $^{*}$ & $\begin{array}{c}\text { Degradação } \\
\text { química }\end{array}$ & $\begin{array}{c}\text { Degradação } \\
\text { biológica }\end{array}$ \\
\hline Muro reforçado & $1,1-2,0$ & $2,0-4,0$ & $1,0-1,5$ & $1,0-1,3$ \\
Aterro reforçado & $1,1-2,0$ & $2,0-3,5$ & $1,0-1,5$ & $1,0-1,3$ \\
Estabilização de taludes & $1,1-1,5$ & $2,0-3,0$ & $1,0-1,5$ & $1,0-1,3$ \\
Rodovias não pavimentadas & $1,1-2,0$ & $1,5-2,5$ & $1,0-1,5$ & $1,0-1,2$ \\
\hline
\end{tabular}

${ }^{*}$ Limites inferiores devem ser aplicados para vida útil curta ou em situações em que a fluência não é crítica

Outra possibilidade para obtenção do fator de redução que considera a fluência dos geossintéticos $\left(\mathrm{FR}_{\mathrm{F}}\right)$ baseia-se nas curvas de ruptura por fluência. A partir dessas curvas, extrapolam-se os resultados até que se atinja a vida útil da obra em questão, obtendo-se a solicitação máxima que pode ser aplicada ao geossintético. Quando expresso em relação à resistência à tração do geossintético, o inverso desse valor $\left(\mathrm{T}_{\text {fluência }}\right)$ resulta no fator de redução por fluência. A Figura 2.28 ilustra esse procedimento.

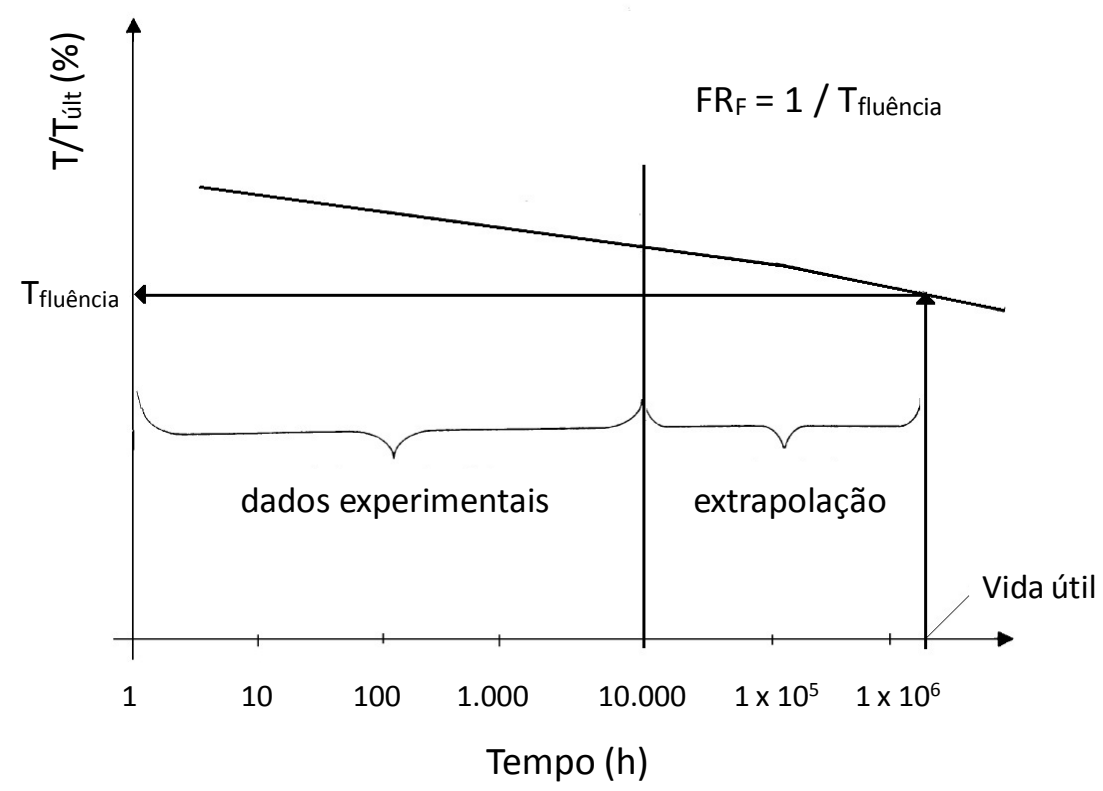

Figura 2.28 - Fator de redução devido à fluência obtido através da curva de ruptura por fluência (COSTA, 1999). 
Entretanto, recomenda-se um número máximo de ciclos logarítmicos a serem extrapolados nesse procedimento, a fim de que não haja perda de precisão. Esse número varia entre um (ASTM D 5262; VERTEMATTI, 2004) e dois ciclos logarítmicos (SEGRESTIN; FREITAG, 2006).

De acordo com Tabela 2.1, o fator de redução por fluência para geotêxteis variam entre 2 e 4 (KOERNER, 2005). Para geogrelhas, esse autor sugere valores entre 2 e 3. Vertematti (2004) propõe valores entre 2 e 5, para qualquer tipo de geossintético. Assim, considera-se uma redução aproximada de 50 a $80 \%$ na resistência à tração do material devido, apenas, ao fenômeno da fluência. 


\section{Materiais e Métodos}

Este capítulo apresenta a descrição dos equipamentos utilizados na realização dos ensaios de fluência em geossintéticos. Adicionalmente, são apresentadas as características dos materiais ensaiados e os procedimentos de preparação e execução dos ensaios.

\subsection{Descrição do equipamento de fluência confinada e acelerada}

O equipamento utilizado para realização dos ensaios de fluência confinada e acelerada foi desenvolvido por França (2012). O principio geral de seu funcionamento assemelha-se ao proposto por McGown et al. (1982) (Figura 2.25), caso em que a solicitação de tração é aplicada diretamente ao geossintético. Embora siga o mesmo principio, esse equipamento apresenta algumas diferenças, que serão descritas a seguir. As informações contidas neste capítulo são baseadas em França, 2012.

$\mathrm{O}$ equipamento de fluência confinada e acelerada consiste de um aparato onde o corpo de prova de geossintético é posicionado horizontalmente em uma câmara de ensaios, na qual o material é solicitado em tração por meio de garras conectadas a pesos livres. A câmara de ensaios é provida de um sistema que possibilita a reprodução de tensões de confinamento, por meio de um solo confinante e uma bolsa de ar pressurizado. Além disso, conta com um sistema de resistências instaladas em seu interior, capaz de produzir temperaturas elevadas ao longo dos ensaios. Além da realização de ensaios simultaneamente confinados e acelerados, esse equipamento pode ser empregado para ensaios separadamente confinados ou acelerados, bem como, ensaios convencionais de fluência em geossintéticos.

A Figura 3.1 apresenta um esquema e uma fotografia desse equipamento, destacando-se seus principais sistemas, que são: responsáveis pela reprodução do confinamento do solo, elevação da temperatura de ensaio, aplicação do carregamento, medição do alongamento do corpo de prova e aquisição dos dados. Salienta-se que algumas alterações foram realizadas no equipamento e serão descritas no item 3.1.7. 


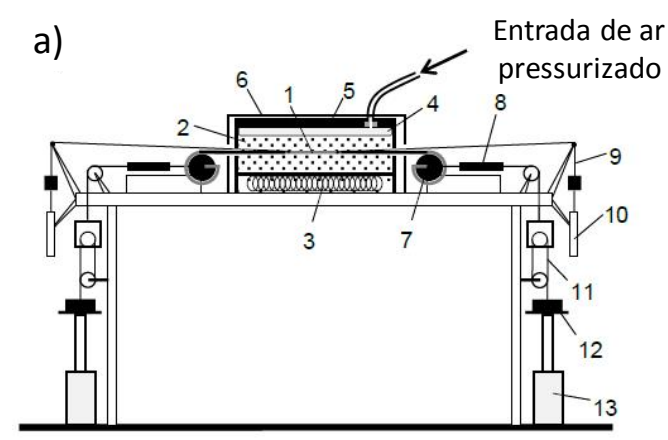

1 - Corpo de prova

2- Compartimento superior da caixa de ensaio (meio confinante e corpo de prova)

3 - Compartimento inferior da caixa de ensaio (sistema de aquecimento)

4 - Bolsa de ar pressurizado

5 - Tampa da câmara de ensaio

6- Cobertura em poliestireno expandido b)

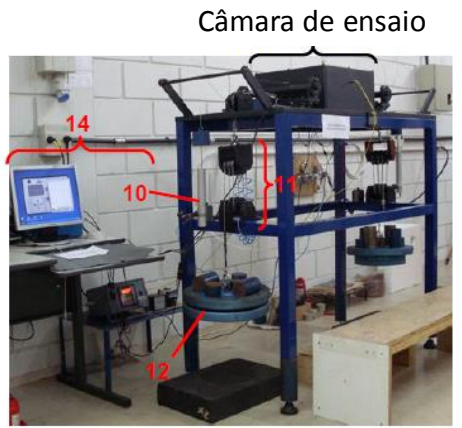

7- Garra do tipo rolete

8 - Célula de carga

9 - Fio de aço inextensível

10 - Transdutor de deslocamento

11 - Conjunto de polias

12 - Peso livre

13- Macaco hidráulico

14 - Sistema de aquisição de dados

Figura 3.1 - (a) Equipamento de fluência confinada e acelerada em geossintéticos; (b) Fotografia do ensaio em execução (FRANÇA, 2012).

A câmara de ensaio desse equipamento apresenta área plana quadrada com 400 mm de aresta, altura de $200 \mathrm{~mm}$, paredes metálicas com 12,5 mm de espessura e é subdividida em dois compartimentos, superior e inferior. A parte inferior apresenta $50 \mathrm{~mm}$ de altura e abriga o sistema de aquecimento (descrito no item 3.1.3). O compartimento superior, com 137,5 mm de altura, acomoda o solo confinante e o corpo de prova de geossintético que será ensaiado. Junto à parte superior é fixada uma tampa, que por sua vez, tem a finalidade de atuar como reação a pressão de ar aplicada à bolsa inflável (com 29,5 mm de altura), gerando uma tensão vertical sobre o solo e consequentemente ao corpo de prova. A Figura 3.2 apresenta um esquema dos compartimentos e partes da câmara de ensaios.

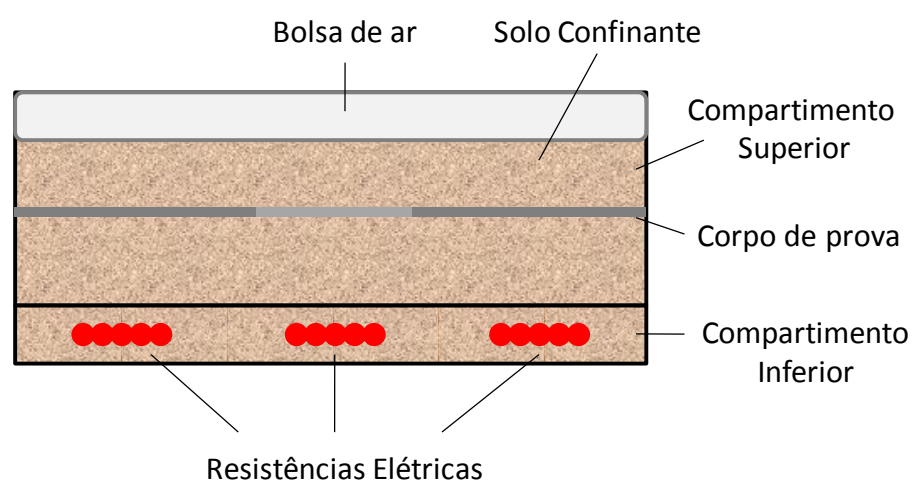

Figura 3.2 - Compartimento superior e inferior da câmara de ensaios. 
As paredes laterais da caixa de ensaio possuem aberturas de $300 \mathrm{~mm}$ de largura por $5 \mathrm{~mm}$ de espessura, que permitem o acesso do corpo de prova a parte externa do equipamento. O corpo de prova é fixado a garras do tipo rolete, que são conectadas por cabos de aço a pesos livres, responsáveis pela aplicação do carregamento de tração. Juntamente, há um conjunto de polias, capaz de multiplicar a solicitação proveniente dos pesos livres. A solicitação de tração é verificada continuamente através de células de cargas instaladas nos cabos de aço. $\mathrm{O}$ alongamento do corpo de prova é medido por transdutores de deslocamento ligados a pontos conhecidos do corpo de prova através de fios de aço inextensíveis. Estes pontos estão em uma faixa de interesse do corpo de prova, que fica em contato com o solo e recebe a tensão de confinamento. Deste modo, o corpo de prova necessita de um processo de preparação antes dos ensaios, prevendo a instalação de fios de aço inextensíveis e reforço na região externa à faixa de interesse (detalhes que serão descritos no item a seguir).

\subsubsection{Configuração dos corpos de prova de geossintético}

Os corpos de prova de geossintéticos utilizados nos ensaios confinados e acelerados passam por um processo de preparação antes da execução do ensaio. Estes apresentam dimensão de $200 \mathrm{~mm}$ de largura por $1.100 \mathrm{~mm}$ de comprimento. A faixa de interesse, onde se processa a fluência encontra-se no meio do corpo de prova, com comprimento de $100 \mathrm{~mm}$. Essas dimensões reproduzem as medidas estabelecidas nos ensaios normalizados de fluência (200 $\mathrm{mm}$ de largura e $100 \mathrm{~mm}$ de comprimento). Esta faixa é delimitada por duas regiões reforçadas com adesivo a base de resina epóxi e recoberta por uma folha de poliéster de $0,075 \mathrm{~mm}$ de espessura. Este procedimento tem por objetivo a redução do atrito na interface área reforçada do geossintético com o solo confinante. A Figura 3.3 apresenta a sequência de preparação dos corpos de prova. 
a)

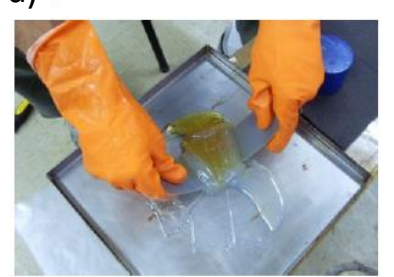

Mistura do adesivo

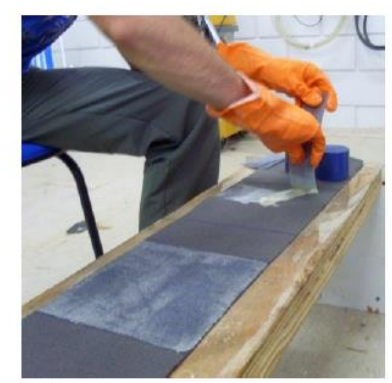

Aplicação do adesivo

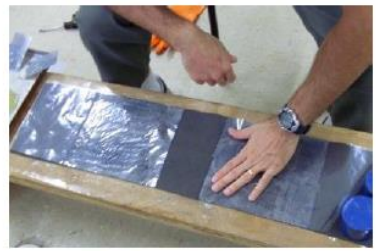

Folha de poliéster

b)

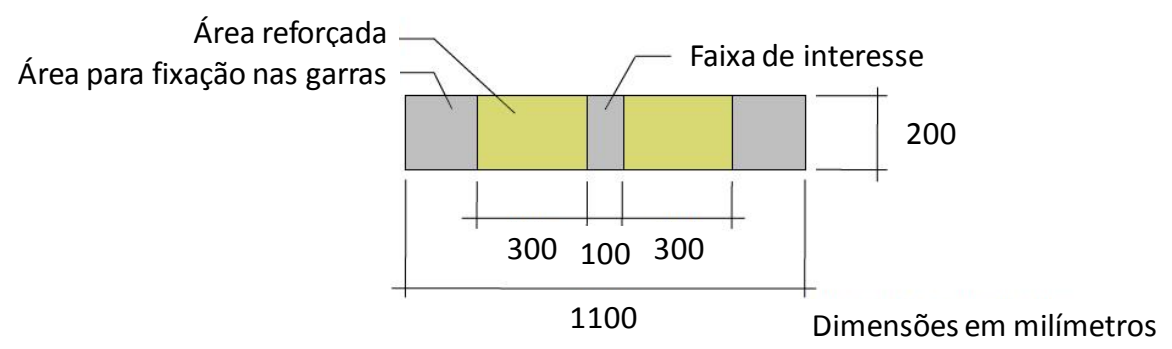

Figura 3.3 - Sequência de preparação dos corpos de prova - (a) Fases do preparo e aplicação do adesivo; (b) Dimensões do corpo de prova (FRANÇA, 2012).

Após a cura do adesivo aplicado nas áreas reforçadas, procede-se à instalação dos fios inextensíveis utilizados na medição do alongamento do corpo de prova. Estes fios são fixados na faixa de interesse, distando 60 a $95 \mathrm{~mm}$ entre si. A Figura 3.4 apresenta a configuração final do corpo de prova de geossintético, onde se observa a medida entre os pontos de fixação dos fios de aço inextensível $\left(\mathrm{L}_{\mathrm{i}}\right)$.

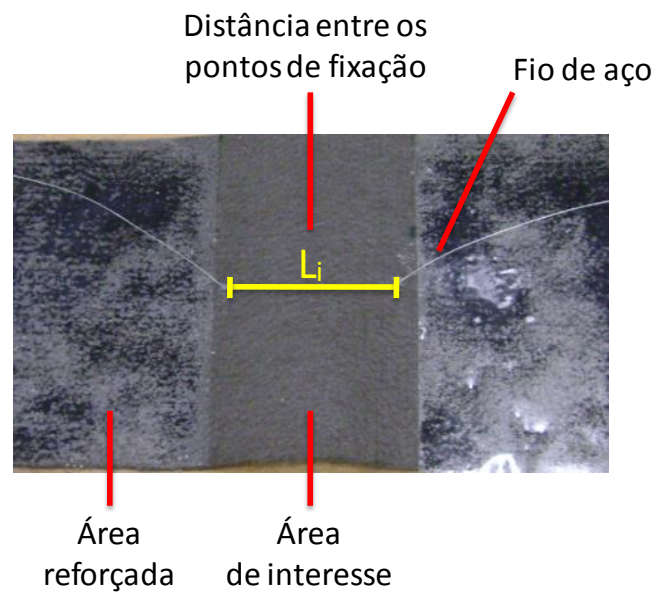

Figura 3.4 - Configuração final do corpo de prova de geossintético, com destaque para a medida da distância entre os pontos de fixação. 
As áreas reforçadas (rígidas) ficam em contato com um par de geomembranas de polietileno de alta densidade (acima e abaixo), de dimensões de $150 \mathrm{~mm}$ de comprimento e $200 \mathrm{~mm}$ de largura. Portanto, o meio confinante não entra em contato com as regiões reforçadas do corpo de prova de geossintéticos. Adicionalmente, aplica-se um lubrificante entre as geomembranas e as regiões reforçadas, reduzindo o atrito de interface e garantindo que a solicitação de tração desejada atinja a faixa de interesse do corpo de prova. Para aplicação deste procedimento, França (2012) realizou um estudo sobre a resistência ao cisalhamento de interface entre as superfícies das geomembranas e o corpo de prova. A Figura 3.5 apresenta a envoltória de resistências obtida nesses ensaios.

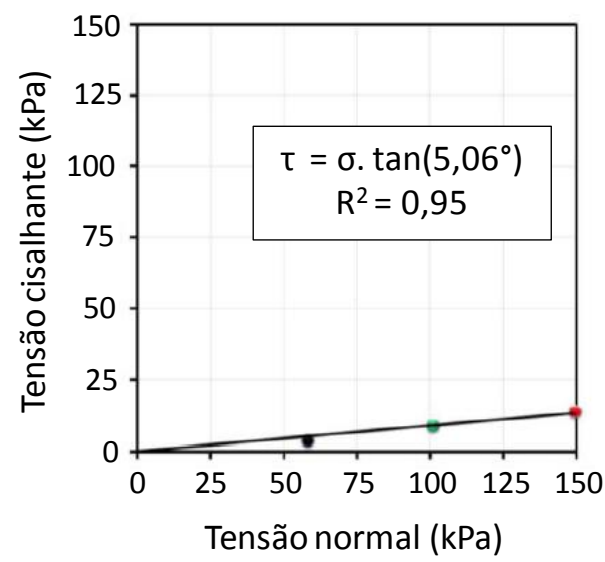

Figura 3.5 - Envoltória de resistências dos ensaios de cisalhamento direto (adaptado de FRANÇA, 2012).

Esses resultados são empregados na determinação da força de atrito desenvolvida no contato entre as geomembranas e o corpo de prova, valor que deve ser acrescido ao carregamento, para que a solicitação de tração desejada atinja a área de interesse do corpo de prova do geossintético. O item 3.1.4 apresenta o procedimento para esse cálculo.

\subsubsection{Sistema de aplicação do confinamento}

O sistema de aplicação da tensão vertical de confinamento consiste no preenchimento da porção superior da câmara de ensaio com o solo e uma bolsa de ar inflável que reage contra a tampa da parte superior da caixa de ensaio. O procedimento para a montagem do sistema de reprodução do confinamento é ilustrado na Figura 3.6. 

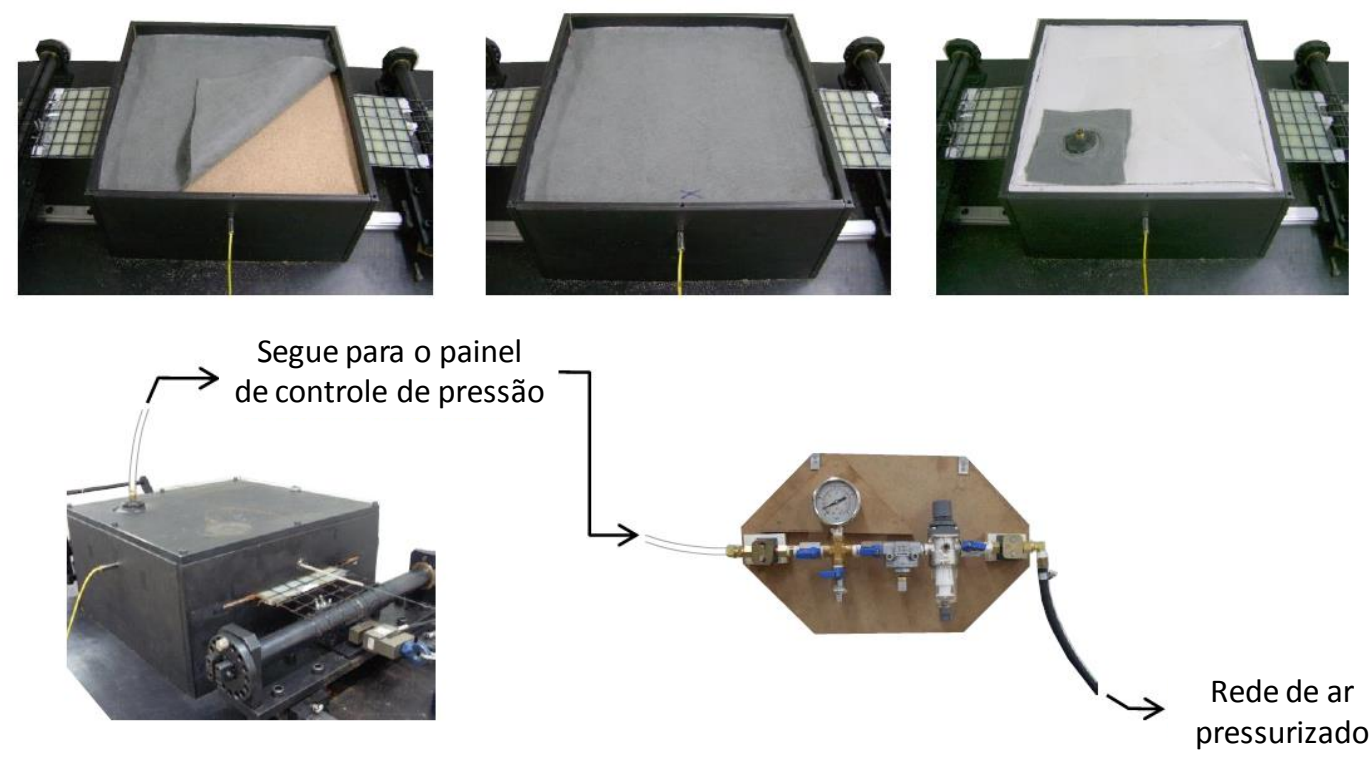

Figura 3.6 - Sequência de montagem do sistema de reprodução do confinamento (FRANÇA, 2012).

Após o lançamento da última camada de solo, um geotêxtil não-tecido é posicionado entre o solo e a bolsa de ar inflável (proteção contra possíveis danos causados pelo solo). Em seguida, a tampa do compartimento superior é fixada a câmara de ensaio. Esta possuiu um orifício que permite a ligação da bolsa ao sistema de ar pressurizado do laboratório. França (2012) empregou como valores nominais de tensão normal aquelas registradas no manômetro do painel de pressão. Este mesmo procedimento foi seguido na execução dos ensaios empregando geossintético confinado.

\subsubsection{Sistema de aquecimento}

O sistema de aquecimento da câmara de ensaio é composto por três resistências elétricas, dois termopares e um controlador de temperaturas com interface computacional. $\mathrm{O}$ conjunto de resistências fica alojado na parte inferior da caixa de ensaios, que é preenchida com solo, a fim de promover uma continuidade maior na propagação de calor. Por fim, este compartimento é fechado, servindo de fundo para a parte superior. Os termopares são divididos em ativo (C1) e passivo (C2), posicionados a $10 \mathrm{~mm}$ das resistências (parte inferior) e $20 \mathrm{~mm}$ acima do corpo de prova de geossintético (parte superior), respectivamente. $\mathrm{O}$ termopar ativo (C1) tem a finalidade de controlar a temperatura nas proximidades das 
resistências e ativá-las de acordo com a temperatura programada no controlador. Já o termopar passivo $(\mathrm{C} 2)$ é utilizado apenas para registrar a temperatura nas proximidades do corpo de prova durante a execução dos ensaios em temperatura elevada. A Figura 3.7 apresenta uma sequência da montagem desse sistema.

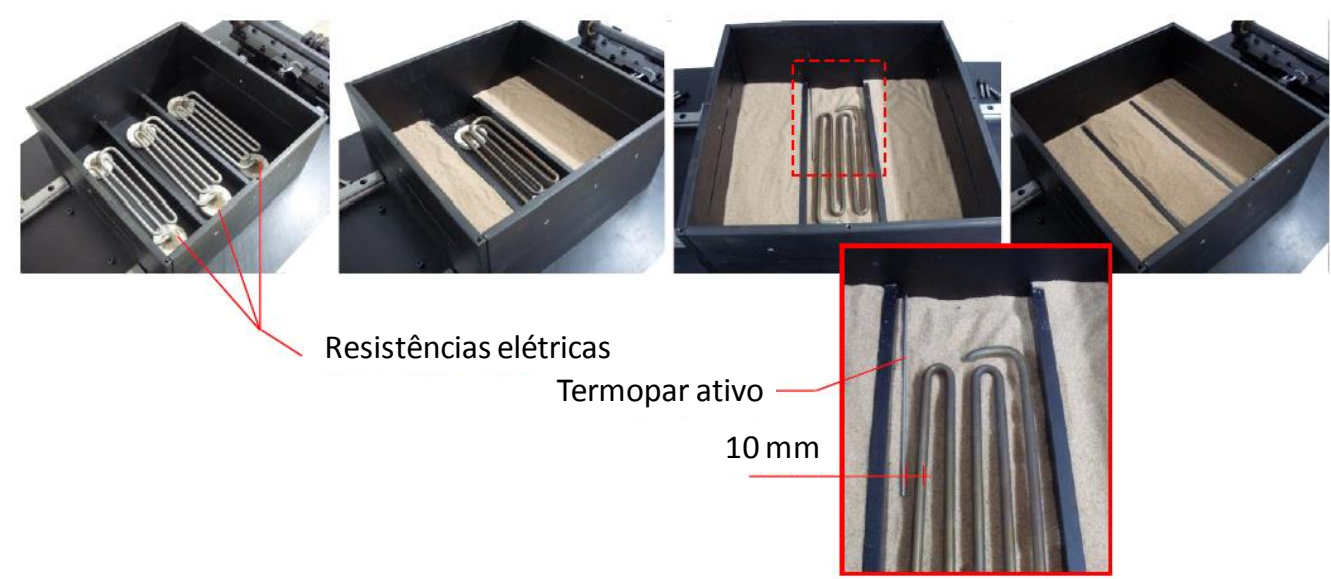

Figura 3.7 - Sistema de aquecimento e posicionamento do termopar ativo (FRANÇA, 2012).

França (2012) realizou um procedimento de calibração do sistema de aquecimento, a fim de determinar qual a temperatura necessária a ser empregada no termopar ativo (C1), para que se obtenha a temperatura desejada no corpo de prova (termopar passivo). Além disso, este autor mostrou que o tempo necessário para atingir a temperatura desejada no compartimento superior (C2) é de aproximadamente $20 \mathrm{~h}$. A curva de calibração desse procedimento é expressa pela relação entre as temperaturas nos termopares $(\mathrm{C} 2=0,716 \mathrm{C} 1+$ 4,852 ), onde $\mathrm{C} 1$ representa a temperatura programada no termopar ativo e $\mathrm{C} 2$ a temperatura lida termopar passivo.

\subsubsection{Sistema de aplicação da solicitação de tração}

O sistema de aplicação da solicitação de tração ao corpo de prova de geossintético é composto por uma garra do tipo rolete apoiada sobre guias lineares (300 mm de curso), que são conectadas a pesos livres por meio de cabos de aço (capacidade nominal de 4,45 kN). Este sistema apresenta um conjunto de polias, com a finalidade de multiplicar o carregamento aplicado (fator de aproximadamente 5,7) e assim, reduzindo consideravelmente a quantidade de pesos livres necessários para reprodução do carregamento. Adicionalmente, conta-se com 
células de carga (capacidade nominal de $500 \mathrm{~kg}$, alimentação de 10 VCC e sinal de saída de 2 $\mathrm{mV} / \mathrm{V} \pm 10 \%$ ) instaladas entre as garras e o sistema de polias, obtendo-se continuamente a solicitação à qual o corpo de prova está submetido durante os ensaios. A Figura 3.8 apresenta o conjunto que compõe o sistema de aplicação do carregamento.

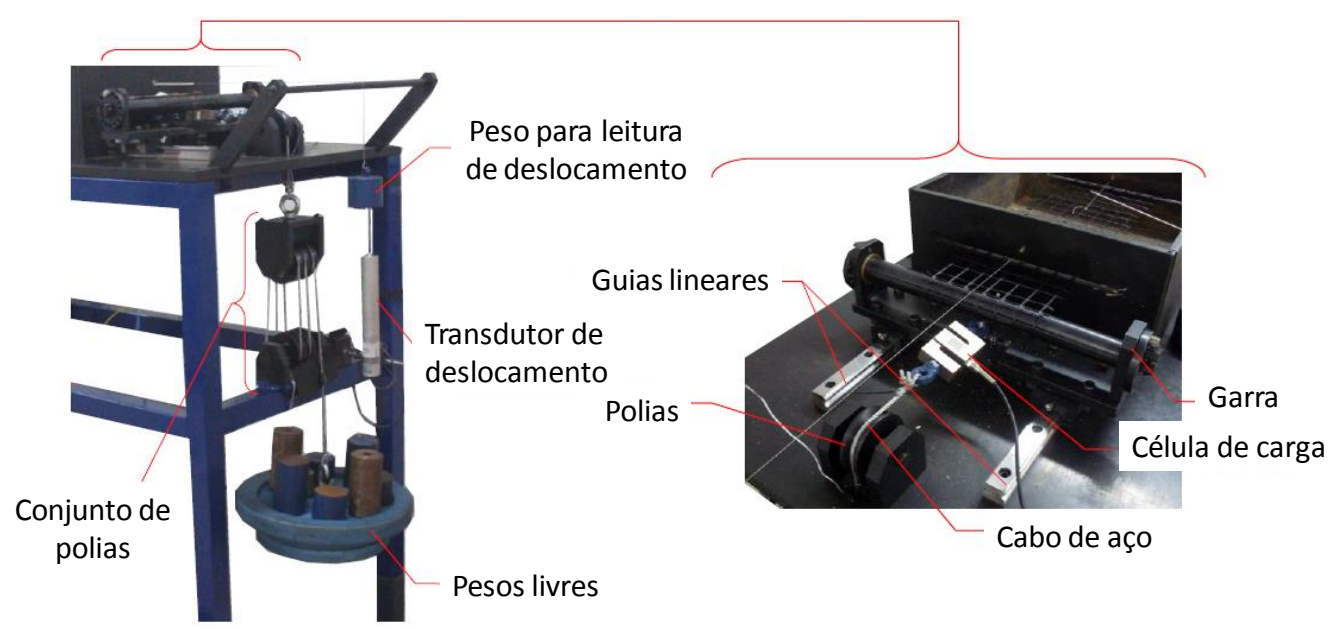

Figura 3.8 - Sistema de aplicação da solicitação de tração (FRANÇA, 2012).

As células de carga utilizadas foram calibradas a fim de verificar as constantes de calibração fornecida pelo fabricante. Neste procedimento, utilizou-se outra célula de carga (capacidade nominal de $2.000 \mathrm{~kg}$ ) acoplada a uma máquina de ensaios EMIC (utilizada para ensaios de tração ou compressão, com capacidade nominal de $3.000 \mathrm{~kg}$ em ambos os sentidos de ensaio). Deste modo, obteve-se o par, carga aplicada (a partir da célula de carga aferida) versus leitura obtida na célula de carga em calibração. A Figura 3.9 apresenta uma foto desse procedimento, juntamente com as curvas de calibração de ambas as células de carga.

a)

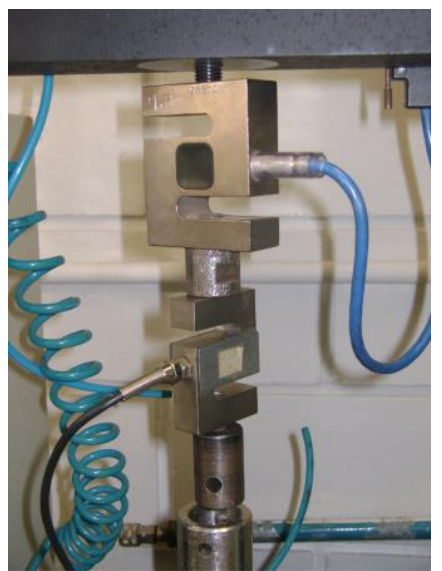

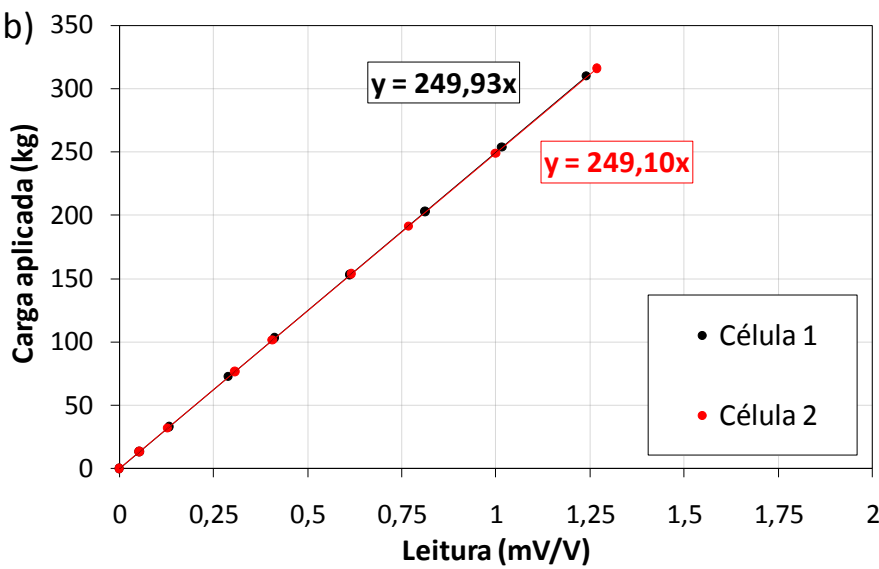

Figura 3.9 - (a) Procedimento de calibração das células de carga; (b) Curvas de calibração. 
Devido à presença do conjunto de polias, após o posicionamento das células de carga ao equipamento de fluência confinada e acelerada, outro procedimento de calibração foi executado. Esta medida teve por objetivo determinar a quantidade de pesos livres necessária para atingir o carregamento de interesse de cada ensaio. Neste procedimento, obteve-se o par, carga lida (célula de carga) versus carga aplicada (incrementada em etapas). Vale ressaltar que cada célula de carga foi calibrada individualmente. A Figura 3.10 apresenta as curvas de calibração desse procedimento. Salienta-se que as constantes 16,84 e 17,60, presentes nas curvas de calibração são atribuídas ao peso do conjunto de polias existentes em cada extremidade do equipamento de fluência confinada e acelerada.

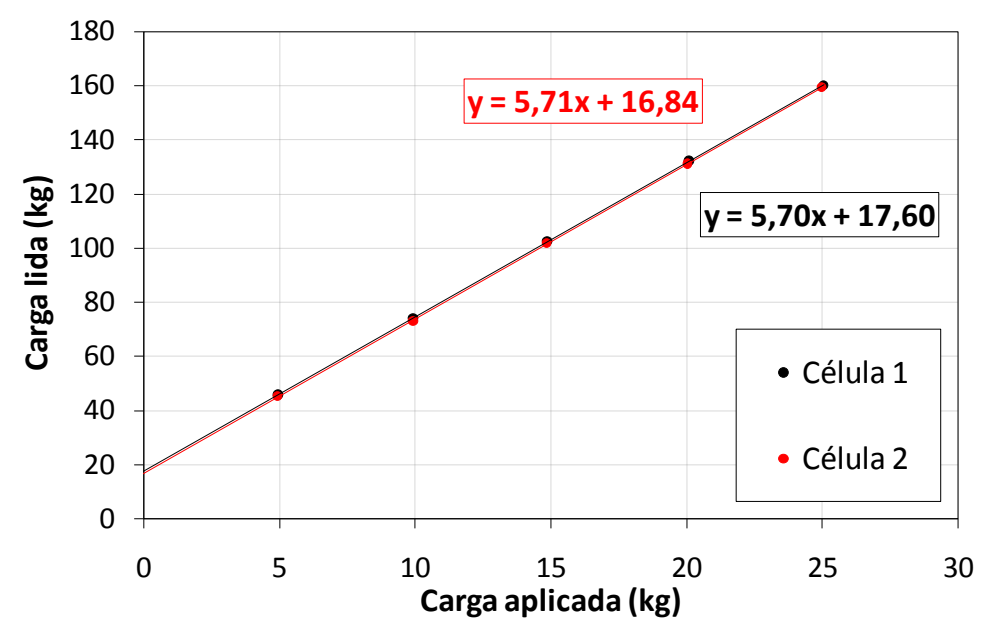

Figura 3.10 - Calibração da célula de carga quando acoplada ao equipamento de fluência confinada e acelerada.

Observa-se que a resposta de ambas as células de carga são muito próximas. Desta forma, optou-se por utilizar a média aritmética dos coeficientes angular e linear, obtendo uma curva média de calibração $(y=5,705 x+17,22)$, onde a variável independente $(x)$ é o carregamento aplicado e a variável dependente (y) o carregamento lido nas células de carga. Salienta-se que este procedimento é utilizado como estimativa da quantidade de pesos livres a serem utilizados, sendo o carregamento corrigido continuamente através da inserção de elementos metálicos.

Adicionalmente, para os ensaios onde são previstas condições de confinamento em solo (tensão normal de aproximadamente $50 \mathrm{kPa}$ ), uma força de atrito é desenvolvida no contato entre as geomembranas e o corpo de prova. Assim, de acordo com os resultados dos 
ensaios de cisalhamento direto de interface geomembrana e corpo de prova apresentado no item 3.1.1, é necessário estimar um acréscimo de carregamento para que a solicitação de tração desejada atinja a área de interesse do corpo de prova do geossintético. Portanto, levando-se em conta que a área de contato entre as geomembranas e a área reforçada do corpo de prova é de $0,03 \mathrm{~m}^{2}(0,15 \times 0,20 \mathrm{~m})$ e que esta ocorre em duas faces (superior e inferior), a força de atrito desenvolvida é de aproximadamente $266 \mathrm{~N}$ (ou uma massa de 27,089 kg). Deste modo, adiciona-se esse valor ao carregamento desejado de ensaio para a determinação dos pesos livres a serem utilizados.

A aplicação do carregamento da solicitação de tração era realizada por meio da liberação da pressão de dois macacos hidráulicos, posicionados um em cada extremidade do equipamento, no qual os pesos livres eram apoiados. Entretanto, França (2012) apresenta algumas desvantagens na aplicação desse sistema, que foi solucionada através da implementação de um novo acessório, que será descrito no item 3.1.7.

\subsubsection{Sistema de medição do alongamento do corpo de prova}

A medição do alongamento do corpo de prova de geossintético é realizada através de leituras do deslocamento de dois pontos conhecidos (dispostos na área de interesse). Estes deslocamentos são medidos por meio de fios de aço inextensíveis (aço inoxidável com capacidade nominal de aproximadamente 22,24 N) fixados em pontos pré-definidos (descritos no item 3.1.1) em uma extremidade e a elementos metálicos (massa de aproximadamente 1,75 $\mathrm{kg}$ ) na outra. As hastes de dois transdutores de deslocamento (curso máximo de $50 \mathrm{~mm} \mathrm{e}$ precisão de $0,01 \mathrm{~mm}$ ) são colocadas em contato com os elementos metálicos, de tal sorte que se registram os deslocamentos verticais dos mesmos. Após amarração dos fios de aço inextensível ao corpo de prova e aos elementos metálicos, utiliza-se adesivo bicomponente, a fim de garantir uma maior fixação entre os mesmos. A Figura 3.11 apresenta detalhadamente o posicionamento de cada elemento descrito. 
a)

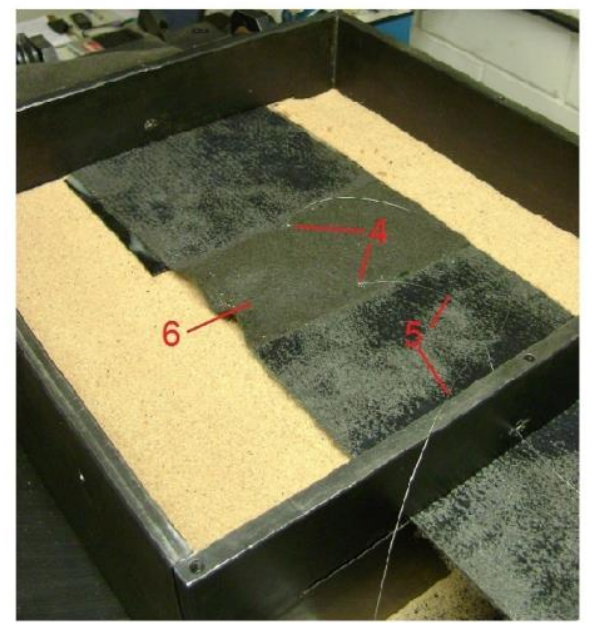

1 - Transdutor de deslocamento (LVDT)

3 - Fixação do fio de aço ao elemento metálico b)

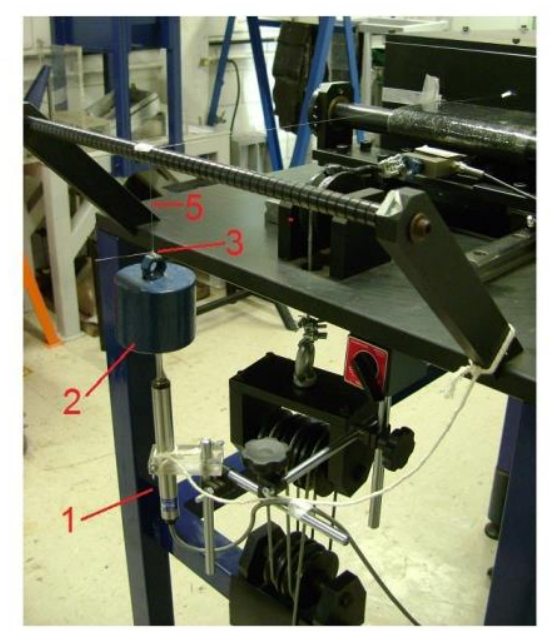

4 - Fixação do fio de aço ao corpo de prova

5 - Fio de aço inextensível

6 - Área de interesse do corpo de prova

Figura 3.11 - Posicionamento dos elementos de medição do alongamento - (a) Pontos de fixação na área de interesse do corpo de prova; (b) Medição do deslocamento vertical dos elementos metálicos.

A partir dos valores dos deslocamentos registrados pelos transdutores de deslocamento, a deformação do corpo de prova pode ser calculada a partir da Equação 11.

$$
\varepsilon=\frac{D_{A}+D_{B}}{L_{i}} .100 \%
$$

onde $\varepsilon$ é a deformação do corpo de prova, em $\% ; D_{A}$ e $D_{B}$ são as leituras dos deslocamentos de cada transdutor de deslocamento, em milímetros; $L_{i}$ é a distância inicial entre os pontos de fixação dos fios de aço inextensíveis na área de interesse, em milímetros (Figura 3.4).

Realizou-se a calibração dos transdutores de deslocamento empregados nesta pesquisa (LVDT - 1 e LVDT - 2). Neste procedimento utilizou-se um relógio comparador e elementos metálicos de diversas espessuras. Assim, obteve-se o par, deslocamento da haste do transdutor (lida no relógio comparador) versus leitura registrada. A Figura 3.12 ilustra a montagem desse procedimento, bem como as curvas de calibração obtidas para cada transdutor. 
a)

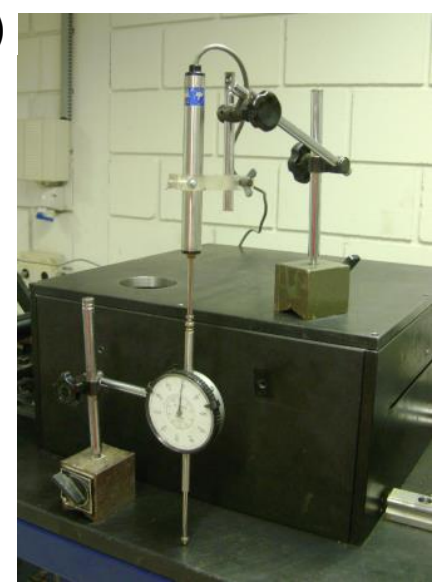

b)

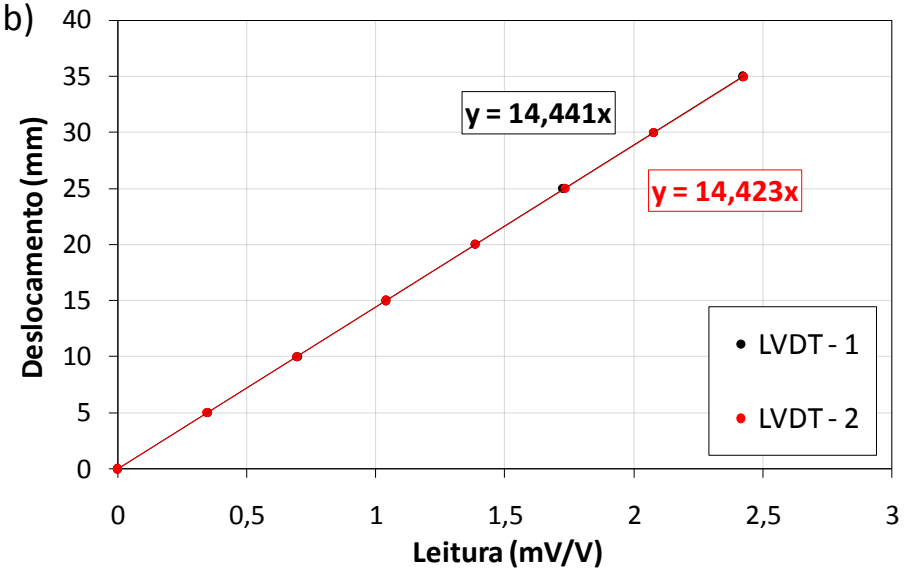

Figura 3.12 - Calibração dos transdutores de deslocamento - (a) Procedimento de calibração; (b) Curvas de calibração.

França (2012) mostrou que este fio de aço inextensível apresenta deformações insignificantes ao longo do tempo, mesmo que em temperaturas elevadas. Entretanto, este autor recomenda que, para os ensaios conduzidos em temperatura elevada, a mesma deve ser atingida antes de iniciar a execução do carregamento ao corpo de prova.

\subsubsection{Sistemas de aquisição de dados}

Dois diferentes sistemas de aquisição foram utilizados para a coleta contínua dos dados dos ensaios. Conforme descrito anteriormente, o equipamento para ensaios de fluência confinada e acelerada conta com duas células de carga (item 3.1.4), dois transdutores de deslocamento (item 3.1.5) e dois termopares (item 3.1.3). As leituras das células de carga e dos transdutores de deslocamento foram adquiridas e registradas por meio do aquisitor Model P3 Strain Indicator and Recorder. Este aparelho possui quatro canais de entrada, funcionando com bateria interna ou alimentação externa. A aquisição e registro dos dados dos termopares foram realizados por um controlador de temperatura, produzido pela Flyever Equipamentos LTD (mesmo fabricante dos termopares). Ambos os sistemas de aquisição possuem interface computacional, o que permitiu o armazenamento contínuo dos dados no mesmo. A Figura 3.13 apresenta os equipamentos utilizados. 
a)

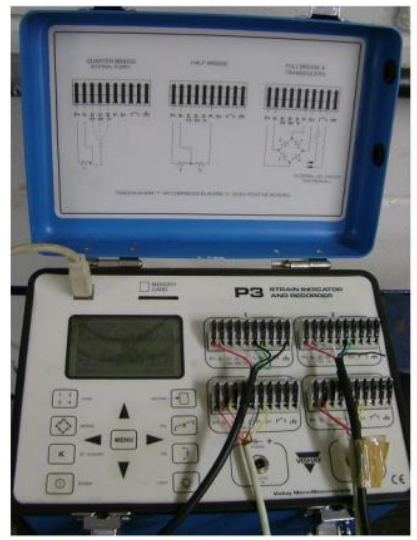

b)

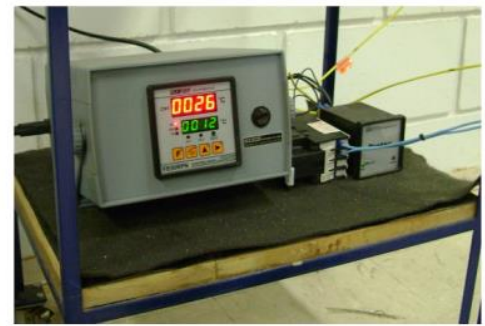

Figura 3.13 - Equipamentos para aquisição dos dados - (a) Model P3 Strain Indicator and Recorder; (b) Controlador de temperatura.

\subsubsection{Melhorias realizadas no equipamento}

França (2012) sugere algumas alterações a serem realizadas ao equipamento de fluência confinada e acelerada, dentre as quais, destaca-se a implementação de um sistema para a aplicação da solicitação de tração ao corpo de prova de geossintético. Este era um procedimento totalmente manual, em que dois operadores, atuando simultaneamente, liberavam a pressão de macacos hidráulicos, nos quais eram dispostos pesos livres. Este procedimento era executado conjuntamente em cada extremidade do equipamento, provocando variações na velocidade de aplicação do carregamento e das deformações iniciais dos corpos de prova.

Para superar esse inconveniente, foi desenvolvido um acessório capaz de aplicar a solicitação de tração de maneira uniforme em ambas às extremidades dos corpos de prova, bem como de manter constante a velocidade de aplicação desse carregamento.

Trata-se de um sistema composto por um motor que ativa o movimento vertical (para cima ou para baixo) de uma viga metálica, na qual são dispostos pesos livres em suas extremidades. Um controlador (inversor de frequência) é utilizado para o ajuste da velocidade do carregamento da solicitação de tração, atuando também como chave do sistema (liga/desliga). Este aparato permite que a solicitação de tração seja aplicada a uma taxa constante e através de apenas um operador. O acessório apresenta um sistema de rodas em sua base, facilitando sua locomoção e ajuste ao equipamento de fluência confinada e acelerada. A 
Figura 3.14 apresenta um esquema deste acessório, bem como sua utilização em um ensaio confinado e acelerado.

a)

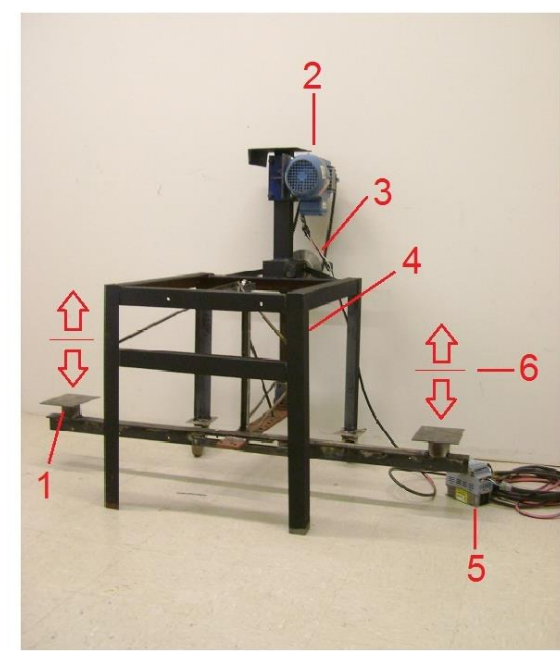

1 - Base de apoio dos pesos livres 2- Motor elétrico

3-Polias

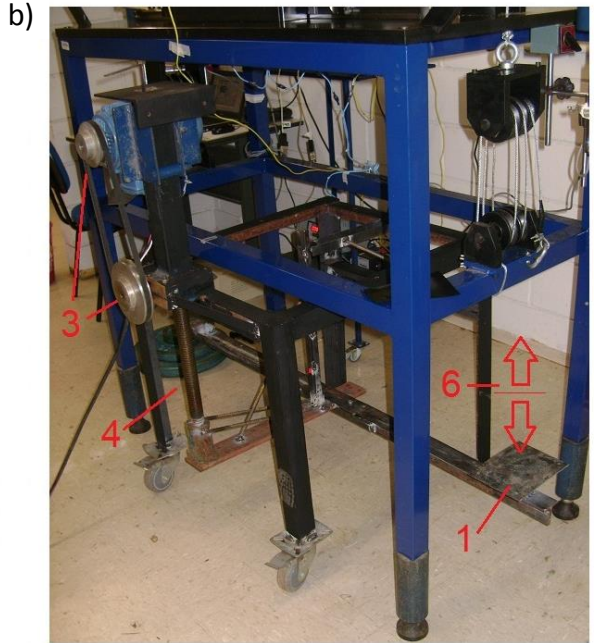

4-Rosca sem fim

5 - Controlador do equipamento (liga/desliga; ajuste da velocidade de carregamento)

6 - Movimento vertical da viga metálica

Figura 3.14 - Acessório empregado para aplicação da solicitação de tração ao corpo de prova de geossintético - (a) Vista frontal; (b) Execução do carregamento em ensaio confinado e acelerado.

Testes mostraram que este acessório é capaz de gerar velocidades de carregamento entre 10 e $200 \mathrm{~mm} /$ minuto. Desta forma, esses valores servem de estimativa para que o carregamento da solicitação de tração atenda as exigências normatizadas (NBR 15.226; ASTM D 5262), ou seja, que o tempo de carregamento não ultrapasse 60 segundos. A Figura 3.15a apresenta as leituras registradas pelas células de carga durante o procedimento de carregamento em um ensaio de fluência confinada, com nível de carregamento igual a 70\% da resistência à tração de um geotêxtil não-tecido. A Figura 3.15b mostra os resultados para o ensaio de fluência confinada e acelerada, com nível de carregamento de $50 \%$ da resistência à tração de uma geogrelha biaxial. Os descarregamentos visualizados na Figura 3.15a são atribuídos ao acomodamento das fibras do corpo de prova de geotêxtil não-tecido, comportamento que não é observado para o corpo de prova da geogrelha biaxial. Observa-se que ambas as curvas registradas pelas células de carga (canal 1 e 2) apresentam-se praticamente paralelas, indicando uma taxa de carregamento constante em ambas as extremidades do equipamento de fluência. 

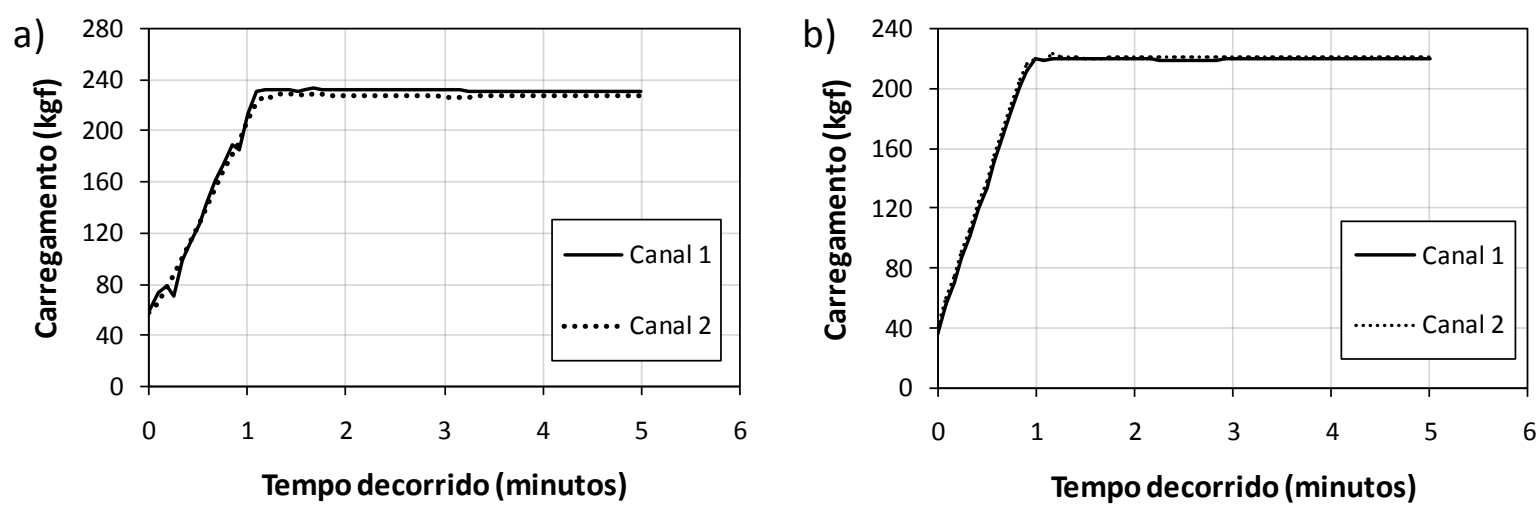

Figura 3.15 - Carregamento da solicitação de tração - (a) Ensaio de fluência confinada a 70\% da resistência a tração de um geotêxtil não-tecido; (b) Ensaio de fluência confinada e acelerada a $50 \%$ da resistência a tração de uma geogrelha biaxial.

Nota-se que tanto para o geotêxtil não-tecido quanto para a geogrelha biaxial, a solicitação de tração desejada é atingida em aproximadamente 60 segundos. Portanto, de acordo com os valores apresentados na Figura 3.15, pode-se afirmar que este acessório atingiu os objetivos propostos, sendo capaz de aplicar a solicitação de tração de maneira uniforme em ambas as extremidades dos corpos de prova, bem como manter constante a velocidade de aplicação do carregamento.

\subsection{Geossintéticos utilizados}

Os ensaios de fluência executados nesse trabalho foram conduzidos com dois tipos de geossintéticos, um geotêxtil não-tecido e uma geogrelha. Buscou-se ainda, usar materiais de mesmo polímero de fabricação. O geotêxtil não-tecido (GTN) é fabricado a partir do processo de agulhamento de fibras curtas de poliéster (PET). A geogrelha (GG) é composta por núcleo de poliéster (PET) e cobertura polimérica de proteção de policloreto de vinila (PVC).

Esses materiais foram submetidos a ensaios de caracterização a partir dos procedimentos normatizados de medição de gramatura (NBR 12.568) e da espessura nominal (NBR 12.569) para o geotêxtil não-tecido e ensaios de resistência à tração (ASTM D 4595 para geotêxteis e ASTM D 6637 para geogrelhas). A Tabela 3.1 apresenta as principais propriedades destes materiais. 
Tabela 3.1 - Resultados dos ensaios de caracterização dos geossintéticos.

\begin{tabular}{ccc}
\hline Características & Geotêxtil não-tecido & Geogrelha biaxial \\
\hline Processo de fabricação & Agulhado & Tecida \\
Polímero predominante & Poliéster & Poliéster \\
Gramatura $\left(\mathrm{g} / \mathrm{m}^{2}\right)$ & $263,7(6,1 \%)^{1}$ & $\mathrm{~N}^{2} \mathrm{~A}^{2}$ \\
Tamanho da abertura $(\mathrm{mm})$ & $\mathrm{N} / \mathrm{A}^{2}$ & 35,0 \\
Espessura nominal $(\mathrm{mm})$ & $2,8(5,6 \%)^{1}$ & $\mathrm{~N}^{2}$ \\
Direção do ensaio & Transversal & Longitudinal \\
Resistência à tração $(\mathrm{kN} / \mathrm{m})$ & $14,11(12,4 \%)^{1}$ & $19,72(1,9 \%)^{1}$ \\
Deformação na ruptura $(\%)$ & $68,12(9,34 \%)^{1}$ & $9,6(4,4 \%)^{1}$
\end{tabular}

1 - $\mathrm{O}$ valor entre parênteses representa o coeficiente de variação;

N/A ${ }^{2}$ - Parâmetro não aplicável.

Os ensaios de tração para ambos os materiais foram conduzidos na máquina universal de ensaios fabricada pela Instron Corporation (capacidade de $250 \mathrm{kN}$ em ensaios de tração e compressão).

\subsection{Solo confinante}

Para os ensaios de fluência em condição de confinamento, empregou-se uma areia de mineração, mal graduada, proveniente de uma jazida localizada no município de Descalvado - SP. Este solo foi caracterizado através de ensaios de análise granulométrica (NBR 7.181), determinação da massa específica dos sólidos (NBR 6.508) e de índices de vazios máximos (NBR 12.004) e mínimos (12.051). Os parâmetros de resistência desse material foram obtidos dos ensaios de cisalhamento direto conduzidos por França (2012). A Figura 3.16 ilustra a curva granulométrica desse solo e a Tabela 3.2 resume as suas principais propriedades.

França (2012) sugere a utilização de areia seca como meio confinante, pois a elevação da temperatura em ensaios confinados de fluência acarretaria alteração do teor de umidade de um solo compactado e, consequentemente, mudanças em suas propriedades. Além disso, a literatura indica que a resistência ao cisalhamento das areias é independente da temperatura (AGAR et al., 1987; GRAHAM et al., 2004). 


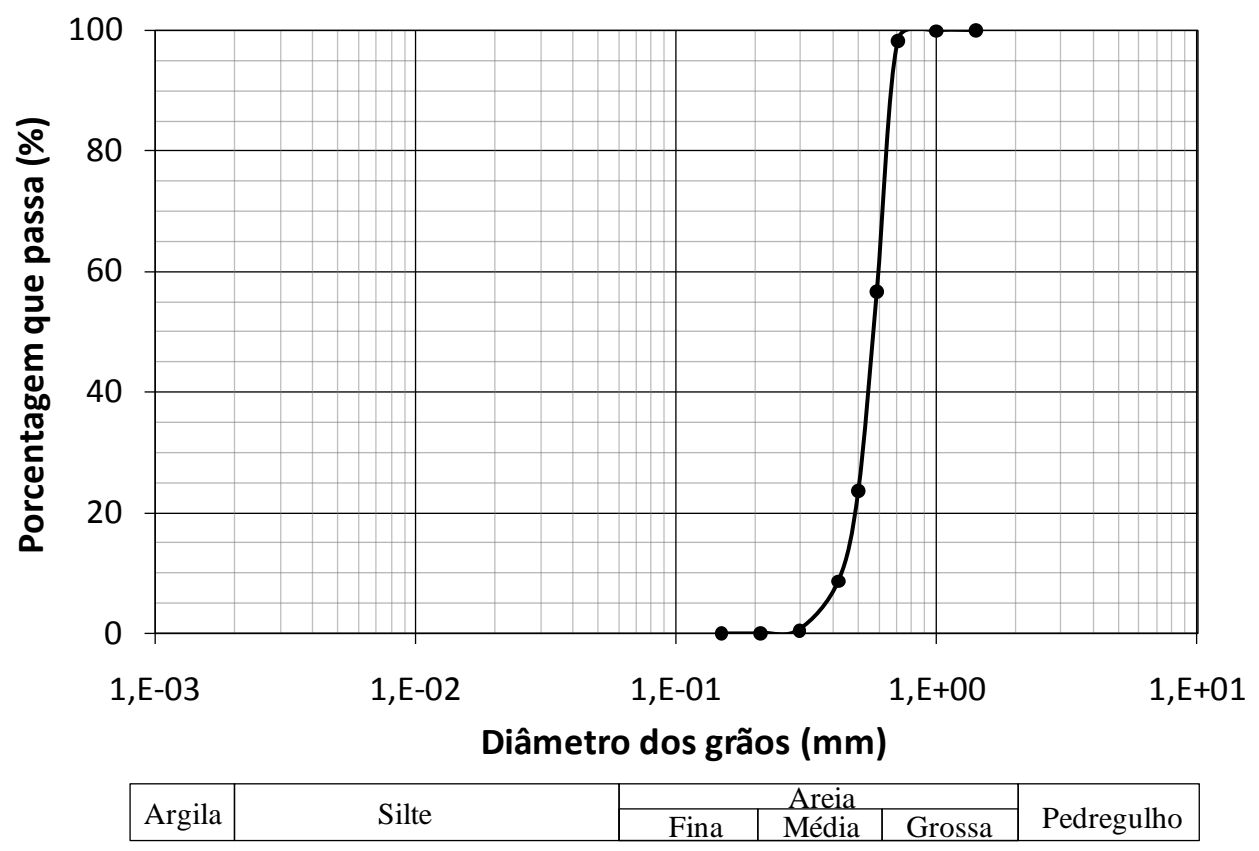

Figura 3.16 - Curva granulométrica do solo confinante utilizado.

Tabela 3.2 - Resultados da caracterização do solo confinante.

\begin{tabular}{cc}
\hline Propriedade & Areia média a grossa \\
\hline Peso específico dos sólidos $\left(\mathrm{kN} / \mathrm{m}^{3}\right)$ & 26,7 \\
Índice de vazios máximo & 0,75 \\
Índice de vazios mínimo & 0,57 \\
Peso específico seco máximo $\left(\mathrm{kN} / \mathrm{m}^{3}\right)$ & 17,0 \\
Teor de umidade $(\%)$ & 0 \\
Fração areia $(\%)$ & 100 \\
Fração silte $(\%)$ & 0 \\
Fração argila $(\%)$ & 0 \\
Classificação SUCS & $\mathrm{SP}$ \\
Ângulo de atrito interno $\left({ }^{\circ}\right)^{1}$ & 34,5 \\
Intercepto coesivo $(\mathrm{kPa})^{1}$ & $\left(\mathrm{D}_{\mathrm{r}}=45 \%\right)$ \\
Coeficiente de empuxo no repouso & 0 \\
\hline
\end{tabular}

${ }^{1}$ - Resultados obtidos por França, 2012. 


\subsection{Descrição dos ensaios realizados}

O programa experimental desta pesquisa é composto por quatro tipos de ensaios de fluência em geossintéticos. Cada ensaio é designado pelo tipo de geossintético utilizado (GTN para o geotêxtil não-tecido e GG para geogrelha), seguido de uma nomenclatura que representa a condição na qual o ensaio foi executado, além de seu respectível nível de carregamento. Os ensaios convencionais de fluência (Conv) foram realizados de acordo com a norma NBR 15.226, em condição de isolamento (não confinado) e em temperatura ambiente. Os ensaios de fluência acelerada (A) também foram conduzidos em condição de isolamento, porém em temperaturas elevadas, ou seja, maiores que a ambiente (acréscimo de temperatura conforme o sugerido pela ASTM D 6992). Os ensaios onde se empregou areia como meio confinante foram designados por ensaios de fluência confinada (C), realizados em temperatura ambiente. Os ensaios conduzidos em meio confinante e em temperatura elevada, foram denominados de ensaio de fluência confinada e acelerada (CA). Alguns ensaios tiveram por objetivo a determinação do tempo de ruptura, denominados de ensaios de ruptura por fluência.

Os ensaios de fluência convencional de ambos os geossintéticos foram realizados em aparatos padronizados (cavalete apresentado na Figura 2.20) e a deformação do corpo de prova determinada a partir da análise de imagens fotográficas, tomadas em tempos prédefinidos. Os demais ensaios de fluência (A, C e CA) foram conduzidos no equipamento de fluência confinada e acelerada desenvolvido por França (2012).

A montagem dos ensaios no equipamento de fluência confinada e acelerada apresenta uma mesma sequência, diferindo apenas quanto à reprodução do meio confinante e elevação de temperatura de ensaio. Portanto, por se tratar do caso mais complexo, o detalhamento da montagem do ensaio confinado e acelerado faz-se necessário. Salienta-se que este procedimento pode ser aplicando aos outros ensaios, subtraindo alguma das etapas descritas, de forma a não reproduzir a referida condição (confinamento em solo e/ou elevação da temperatura de ensaio). Além disso, França (2012) apresenta os procedimentos e descrições detalhadas para a desmontagem dos ensaios no equipamento de fluência confinada e acelerado. 


\subsubsection{Montagem do ensaio de fluência confinada e acelerada}

O procedimento de montagem do ensaio de fluência inicia-se com a preparação do corpo de prova (descrito no item 3.1.1), no qual são fixados os fios inextensíveis em pontos pré-definidos da área de interesse, medindo-se a distância inicial entre esses pontos. Posteriormente, procede-se com o preenchimento do compartimento superior da câmara de ensaios. As etapas desse processo estão ilustradas na Figura 3.17.

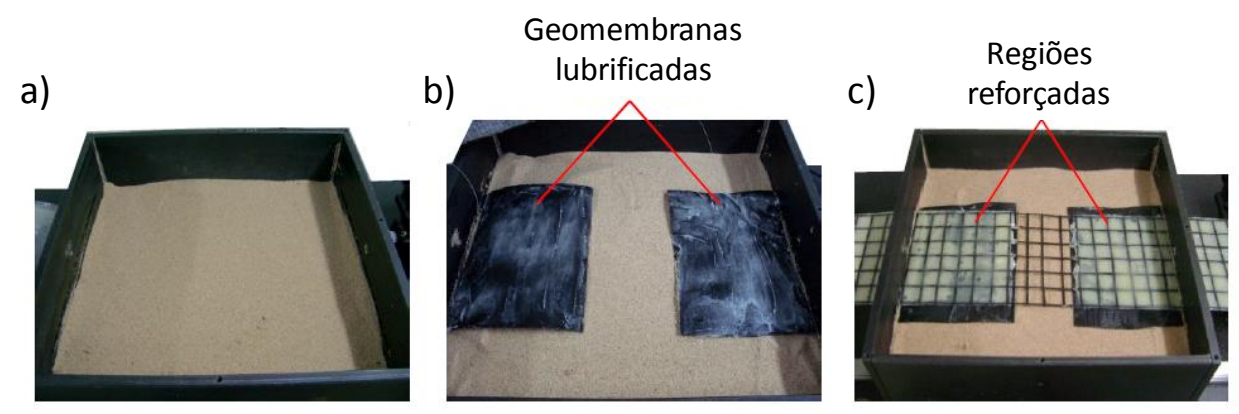

d)

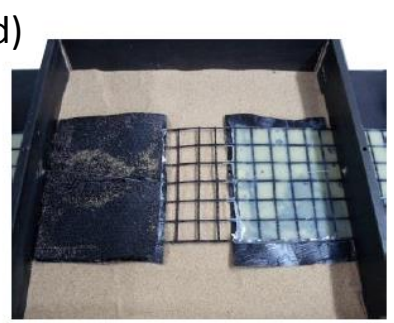

e)

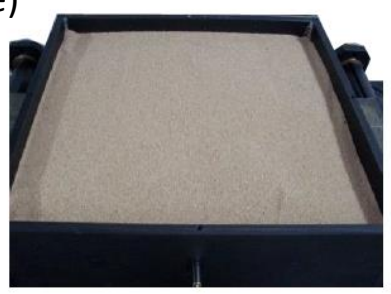

Figura 3.17 - Etapas de montagem do compartimento superior da câmara de ensaios (FRANÇA, 2012).

O procedimento de preenchimento é realizado em duas fases, na qual, primeiramente a câmara é preenchida em três camadas, até o nível inferior da abertura lateral, por onde o corpo de prova tem acesso ao lado externo (Figura 3.17a). Cada porção é lançada e nivelada manualmente. Após, as geomembranas são dispostas sobre o solo confinante (Figura 3.17b). Realiza-se o posicionamento do corpo de prova e novamente são dispostas geomembranas sobre o mesmo (Figura 3.17c e d). Uma vaselina industrial é aplicada entre as geomembranas e a área reforçada do corpo de prova.

Em seguida, executa-se a segunda fase do preenchimento do compartimento superior até atingir cerca de $30 \mathrm{~mm}$ do topo da câmara de ensaios (Figura 3.17e). Salienta-se que todo o lançamento do solo é realizado de cerca de $20 \mathrm{~mm}$ de altura, a fim de que o 
material atinja densidade relativa de $45 \%$ após o termino do processo. Ao fim dessa etapa, a bolsa de ar inflável é disposta acima do meio confinante (protegida por um geotêxtil nãotecido) e a câmara é fechada (etapas apresentadas na Figura 3.6). Conecta-se a bolsa de ar inflável ao sistema de ar pressurizado do Laboratório e aplica-se pressão de $50 \mathrm{kPa}$ de confinamento (valor empregado na execução de todos os ensaios em condição de confinamento). Por fim são dispostos os termopares (registro da temperatura) e os elementos metálicos aos transdutores de deslocamento. Inicia-se a aquisição de dados de deslocamento registrados pelos transdutores de deslocamento.

O ajuste da temperatura é realizado levando-se em consideração a diferença de temperatura entre os compartimentos superior e inferior (calibração apresentada no item 3.1.3). Após a estabilização da temperatura desejada, o acessório desenvolvido para aplicação da solicitação de tração ao corpo de prova (item 3.1.7) é posicionado junto ao equipamento de fluência confinada e acelerada e é carregado com os pesos necessários para atingir as tensões desejadas.

\subsection{Ensaios realizados}

Os ensaios de fluência realizados nos geossintético utilizados nesta pesquisa foram agrupados segundo três objetivos específicos. Primeiramente, os ensaios conduzidos com geotêxtil não-tecido (GTN) permitiram a avaliação da influência do confinamento e da temperatura no comportamento em fluência desse material. Em seguida, ensaios de ruptura por fluência (carregamentos elevados em relação à resistência a tração) foram executados nesse geossintético, com o objetivo de avaliar a influência do confinamento no tempo necessário para que ocorra a ruptura por fluência desse material. Por fim, os ensaios de fluência executados na geogrelha (GG), avaliando a influência do confinamento nas deformações por fluência desse material. A última opção de ensaio foi motivada pelos resultados apresentados por França (2012), onde o confinamento da geogrelha estudada levou a uma redução de $94,2 \%$ na taxa de deformações. Adicionalmente, para o último objetivo apresentado, avaliou-se também a influência da temperatura quanto às deformações por fluência. Os dois geossintéticos foram submetidos a ensaios convencionais de fluência, que serviram de comparação (controle) aos resultados obtidos em cada condição imposta aos ensaios de fluência (acelerado; confinado; confinado e acelerado). 
A Tabela 3.3 sumariza o programa de ensaios realizados para cada tipo de geossintéticos. Nesta tabela também são apresentadas as características de cada ensaio, conforme nomenclaturas descritas acima.

Tabela 3.3 - Características desejadas para os ensaios de fluência realizados em cada tipo de geossintético.

\begin{tabular}{|c|c|c|c|c|c|c|c|}
\hline \multirow{2}{*}{ Geossintético } & \multirow{2}{*}{ Parâmetros } & \multicolumn{6}{|c|}{ Ensaios de Fluência ${ }^{1}$} \\
\hline & & Conv & $\bar{A}$ & $\mathrm{C}$ & & CA & \\
\hline \multirow{3}{*}{ GTN } & $\begin{array}{l}\text { Nível de Carregamento } \\
(\%)^{2}\end{array}$ & 20 a 90 & 50 & $\begin{array}{c}50,70 \\
80^{4} \text { e } 90^{4}\end{array}$ & 50 & 70 & 80 \\
\hline & Confinamento $(\mathrm{kPa})^{3}$ & - & - & 50 & 50 & 50 & 50 \\
\hline & Temperatura de ensaio & Ambiente & $36^{\circ} \mathrm{C}$ & Ambiente & $36^{\circ} \mathrm{C}$ & $\begin{array}{c}36,48 \mathrm{e} \\
60^{\circ} \mathrm{C}\end{array}$ & $36^{\circ} \mathrm{C}$ \\
\hline \multirow{3}{*}{ GG } & $\begin{array}{l}\text { Nível de Carregamento } \\
\qquad(\%)^{2}\end{array}$ & 20 a 50 & 50 & $50^{4}$ & & 50 & \\
\hline & Confinamento $(\mathrm{kPa})^{3}$ & - & - & 50 & & 50 & \\
\hline & Temperatura de ensaio & Ambiente & $36^{\circ} \mathrm{C}$ & Ambiente & & $36^{\circ} \mathrm{C}$ & \\
\hline
\end{tabular}

1 - Convencional (Conv); acelerado (A); confinado (C); confinado e acelerado (CA);

2 - Solicitação de tração referente a porcentagem da resistência à tração do geossintético;

3 - Pressão de confinamento imposta aos ensaios;

4 - Ensaios repetidos.

Conforme pode ser visto na Tabela 3.3, para os ensaios executados em condição de confinamento em solo, empregou-se pressão de $50 \mathrm{kPa}$ na bolsa de ar. Para os ensaios conduzidos em temperatura elevada, adotaram-se saltos de temperatura de aproximadamente $12^{\circ} \mathrm{C}$, atendendo a proposta apresentada pela ASTM D 6992, que sugere um acréscimo de no máximo $14^{\circ} \mathrm{C}$ para geossintéticos manufaturados de poliéster.

Devido à variabilidade apresentada na resistência à tração do geotêxtil não-tecido (apresentado na Tabela 3.1), optou-se por avaliar a relação entre a resistência à tração e a gramatura dos corpos de prova desse geossintético. Esta análise foi composta pela execução de 15 ensaios de resistência à tração de faixa larga (ASTM D 4595), onde posteriormente obteve-se a relação entre a resistência à tração e a respectiva gramatura de cada corpo de prova do GTN. Este estudo teve por objetivo a determinação da resistência à tração de cada corpo de prova isoladamente, a partir de sua respectiva gramatura, valor que foi empregado 
para a correção do nível de carregamento (porcentagem da resistência à tração do geossintético) aplicado a cada ensaio de fluência conduzido com o geotêxtil não-tecido. A Figura 3.18 ilustra a relação entre a resistência à tração e a gramatura do geotêxtil não-tecido de poliéster.

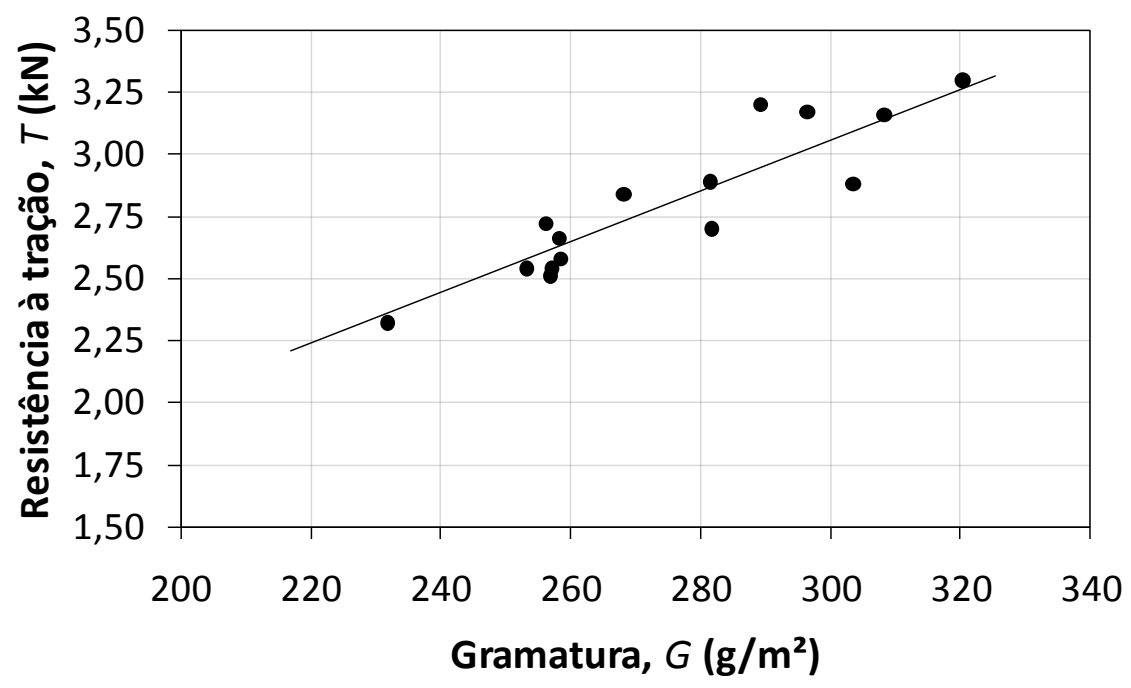

Figura 3.18 - Relação entre a resistência à tração e a gramatura de cada corpo de prova de geotêxtil não-tecido.

O ajuste linear desses pontos resultou na equação de regressão linear indicada na Equação 12.

$$
T=0,010 . G
$$

onde $T$ é a resistência à tração do geotêxtil não-tecido, em $\mathrm{kN}$; $G$ é a gramatura do geossintético, $\mathrm{em} \mathrm{g} / \mathrm{m}^{2}$. O ajuste aplicado a esses pontos resultou em um $\mathrm{R}^{2}$ igual a 0,83 .

A partir desta relação, juntamente com cada gramatura, pôde-se determinar a resistência à tração de cada corpo de prova utilizado nos ensaios de fluência. Desta forma, este valor foi empregado para a correção do nível de carregamento de cada ensaio. A Tabela 3.4 apresenta os carregamentos nominais desejados para cada ensaio, bem como os valores do carregamento real atuante, após correção. 
Tabela 3.4 - Solicitação de tração corrigida de cada ensaio de fluência realizado.

\begin{tabular}{|c|c|c|c|}
\hline Geossintético & $\begin{array}{l}\text { Nomenclatura do } \\
\text { ensaio }\end{array}$ & $\begin{array}{l}\text { Carregamento } \\
\text { nominal }(\%)^{1}\end{array}$ & $\begin{array}{l}\text { Carregamento } \\
\text { real }(\%)^{1}\end{array}$ \\
\hline \multirow{18}{*}{ GTN } & C 90\% ${ }^{2}$ & 90 & 95 \\
\hline & C $80 \%$ & 80 & 85 \\
\hline & $\mathrm{CA} 80 \%-\mathrm{T}=36^{\circ} \mathrm{C}^{2}$ & 80 & 88 \\
\hline & C 70\% & 70 & 70 \\
\hline & $\mathrm{CA} 70 \%-\mathrm{T}=36^{\circ} \mathrm{C}$ & 70 & 67 \\
\hline & $\mathrm{CA} 70 \%-\mathrm{T}=48^{\circ} \mathrm{C}$ & 70 & 69 \\
\hline & $\mathrm{CA} 70 \%-\mathrm{T}=60^{\circ} \mathrm{C}^{2}$ & 70 & 69 \\
\hline & C $50 \%$ & 50 & 50 \\
\hline & $\mathrm{CA} 50 \%-\mathrm{T}=36^{\circ} \mathrm{C}$ & 50 & 52 \\
\hline & A $50 \%-\mathrm{T}=36^{\circ} \mathrm{C}$ & 50 & 51 \\
\hline & Conv $90 \%^{2}$ & 90 & 90 \\
\hline & Conv $80 \%$ & 80 & 80 \\
\hline & Conv $70 \%$ & 70 & 70 \\
\hline & Conv $60 \%$ & 60 & 60 \\
\hline & Conv $50 \%$ & 50 & 50 \\
\hline & Conv $40 \%$ & 40 & 40 \\
\hline & Conv $30 \%$ & 30 & 30 \\
\hline & Conv $20 \%$ & 20 & 20 \\
\hline \multirow{7}{*}{ GG } & C $50 \%$ & 50 & 50 \\
\hline & $\mathrm{CA} 50 \%-\mathrm{T}=36^{\circ} \mathrm{C}$ & 50 & 50 \\
\hline & A $50 \%-\mathrm{T}=36^{\circ} \mathrm{C}$ & 50 & 50 \\
\hline & Conv $50 \%$ & 50 & 50 \\
\hline & Conv $40 \%$ & 40 & 40 \\
\hline & Conv $30 \%$ & 30 & 30 \\
\hline & Conv $20 \%$ & 20 & 20 \\
\hline
\end{tabular}

1 - Solicitação de tração referente a porcentagem da resistência à tração do material; 2 - Ensaios de ruptura por fluência.

A comparação entre os resultados dos ensaios de fluência nas diversas condições analisadas foi realizada a partir da avaliação das curvas de fluência desses materiais, conforme a abordagem sugerida por Zornberg et al. (2004). Assim, o parâmetro de avaliação do comportamento em deformação por fluência foi o índice de fluência $\left(T_{\alpha}\right)$. Este parâmetro indica a inclinação da curva de fluência, conforme descrito no item 2.2. Os ensaios 
conduzidos em temperatura elevada, por sua vez, foram interpretados segundo o conceito do fator de translação (item 2.4.2). 


\section{Resultados e Discussões}

Os resultados obtidos nos diferentes tipos de ensaios de fluência são apresentados e discutidos neste capítulo.

\subsection{Geotêxtil não-tecido de poliéster (GTN)}

A caracterização da fluência do GTN foi realizada por meio de uma série de ensaios convencionais conduzidos em duas abordagens distintas. Primeiramente o objetivo foi a caracterização do comportamento em deformação por fluência deste geossintético. Neste caso, empregaram-se níveis de carregamento entre 20 e $60 \%$ da resistência à tração, no sentido transversal do material e mantidos por no mínimo 1.000 horas de ensaio. Em seguida, foram executados ensaios convencionais com carregamentos entre 60 e $90 \%$ da resistência à tração, também no sentido transversal do material. $O$ objetivo destes ensaios foi a determinação do tempo de ruptura por fluência do geossintético. Entretanto, apenas o ensaio com carregamento de $90 \%$ apresentou ruptura dentro do intervalo de 1.000 horas, com tempo de ruptura de aproximadamente 18 minutos. A Figura 4.1 ilustra os resultados dos ensaios convencionais de fluência realizados no GTN para os níveis de carregamento entre 20 e $90 \%$. Em conjunto são apresentadas as curvas obtidas por regressão logarítmica dos dados, que levaram a uma relação conforme indicado na Equação 13.

$$
\varepsilon=a \cdot \log (t)+b
$$

onde $\varepsilon$ é a deformação total do corpo de prova, em $\% ; t$ representa o tempo decorrido de ensaio, em horas; as constantes $a$ e $b$, obtidas através do ajuste logarítmico, representam a taxa de deformação por fluência e a deformação inicial do geotêxtil não-tecido, respectivamente. 


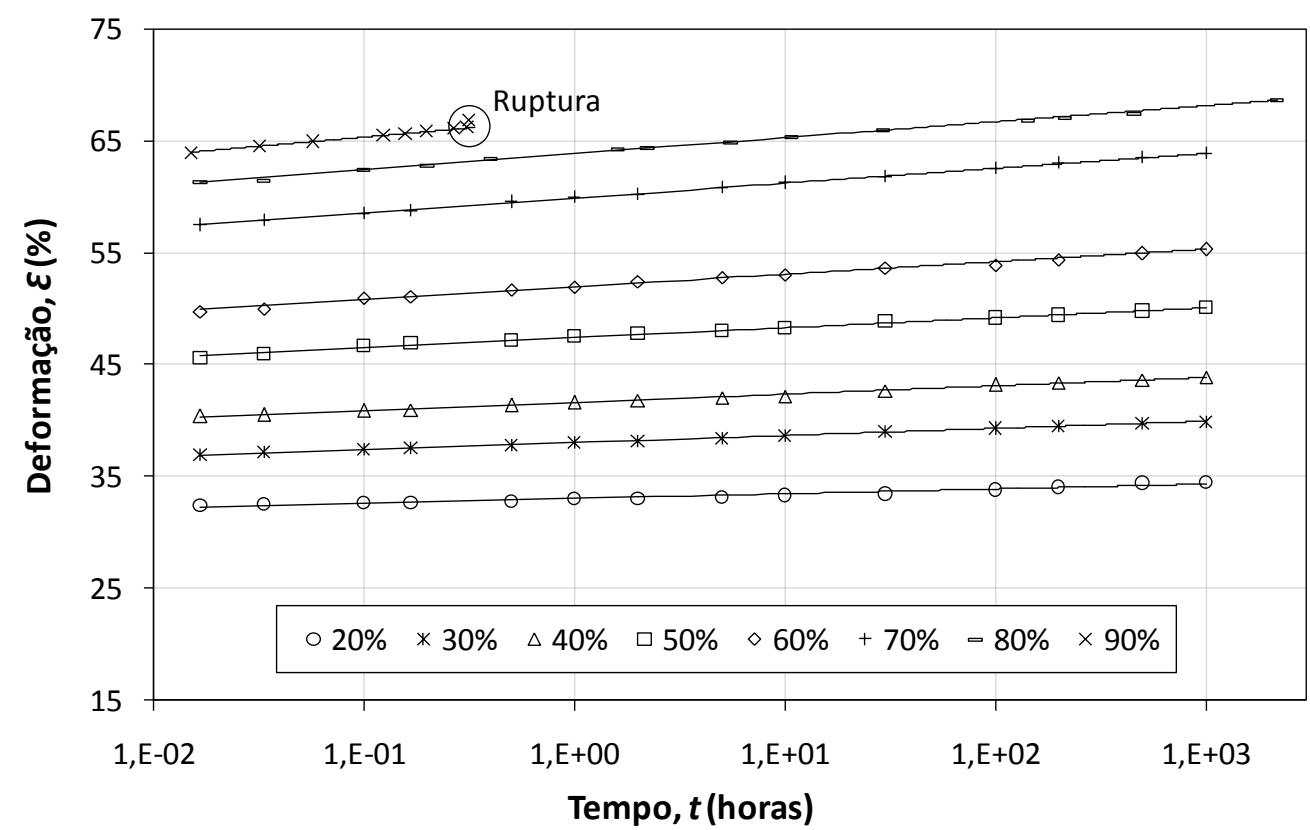

Figura 4.1 - Curvas de fluência obtidas nos ensaios convencionais de fluência conduzidos no GTN (comportamento em deformação por fluência para os níveis de carregamento entre 20 e $80 \%$ e ruptura por fluência para o nível de carregamento de 90\%).

A Tabela 4.1 apresenta os parâmetros obtidos pelo ajuste de uma curva logarítmica (Equação 13) para cada ensaio.

Tabela 4.1 - Parâmetros obtidos pelas curvas de regressão logarítmica de cada ensaio convencional conduzido no GTN.

\begin{tabular}{ccccc}
\hline $\begin{array}{c}\text { Nível de } \\
\text { carregamento } \\
\text { nominal (\%) }\end{array}$ & $\begin{array}{c}\text { Deformação } \\
\text { inicial }(\%)^{2}\end{array}$ & $\mathrm{a}$ & $\mathrm{b}$ & $\mathrm{R}^{2}$ \\
\hline 90 & 63,96 & 1,714 & 67,07 & 0,99 \\
80 & 61,29 & 1,430 & 63,84 & 0,99 \\
70 & 57,52 & 1,345 & 59,91 & 0,99 \\
60 & 49,74 & 1,180 & 51,93 & 0,99 \\
50 & 45,64 & 0,963 & 47,45 & 0,99 \\
40 & 40,41 & 0,710 & 41,62 & 0,99 \\
30 & 36,94 & 0,623 & 38,02 & 0,99 \\
20 & 32,43 & 0,378 & 33,00 & 0,96 \\
\hline
\end{tabular}

1 - Porcentagem da resistência à tração do material (T/ $\left.\mathrm{T}_{\text {últ }}\right)$;

2 - Deformação inicial obtida a partir da análise de cada ensaio. 
A representação gráfica dos ensaios convencionais de fluência conduzidos no GTN também pode ser apresentada apenas em termos de deformação por fluência, na qual se desconsideram as deformações iniciais. Deste modo, os resultados são novamente ilustrados na Figura 4.2, segundo a proposta de Zornberg et al. (2004). Essa representação apresenta o conceito de índice de fluência $\left(\mathrm{T}_{\alpha}\right)$, conforme descrito no item 2.2. Este parâmetro representa a inclinação das curvas de ajuste (Equação 14) e estão apresentados na Tabela 4.2.

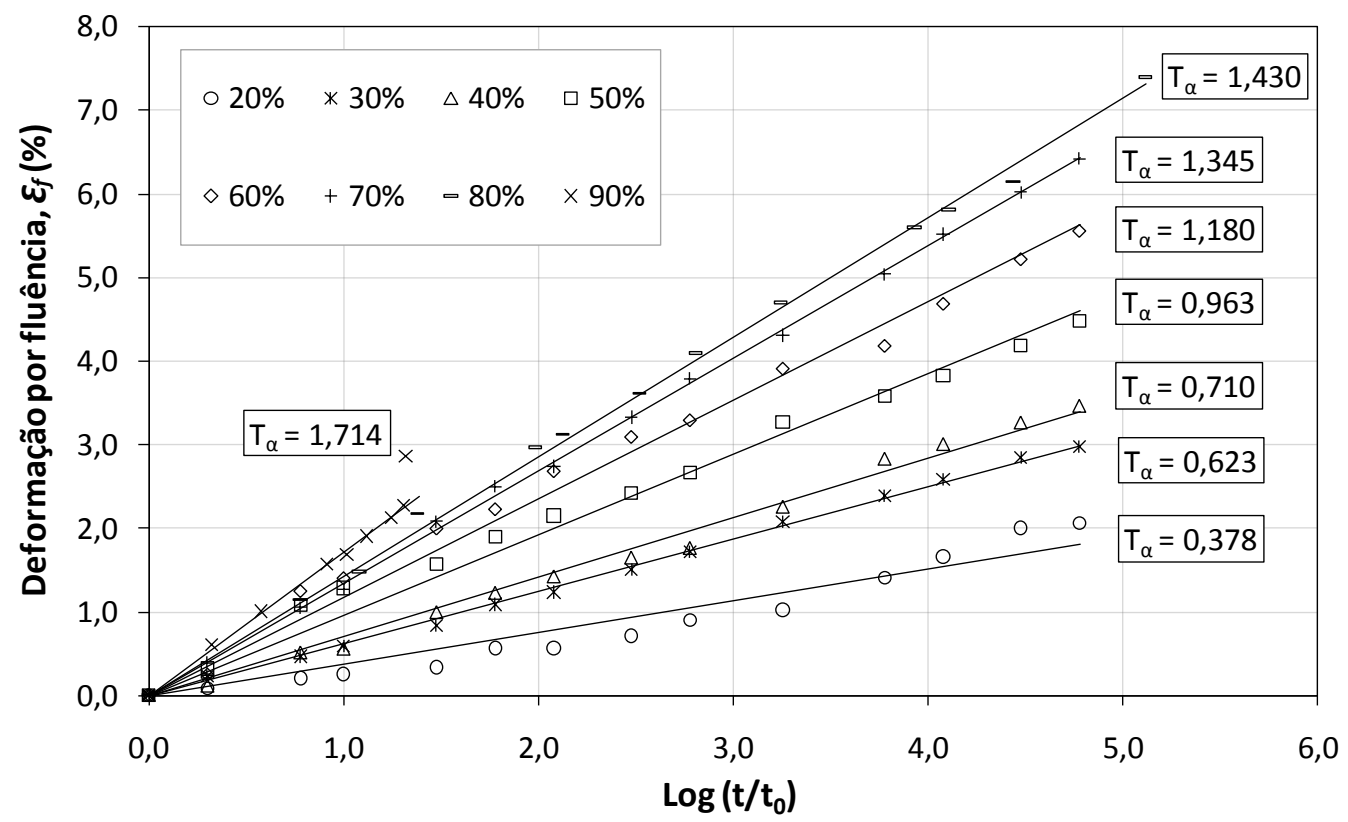

Figura 4.2 - Deformações por fluência obtidas nos ensaios convencionais de fluência conduzidos no GTN, segundo a proposta de Zornberg et al. (2004).

Tabela 4.2 - Índices de fluência obtidos nos ensaios de fluência convencional conduzidos no GTN.

\begin{tabular}{cc}
$\begin{array}{c}\text { Nível de carregamento nominal } \\
(\%)^{1}\end{array}$ & Índice de fluência, $T_{\alpha}$ \\
\hline 90 & 1,714 \\
80 & 1,430 \\
70 & 1,345 \\
60 & 1,180 \\
50 & 0,963 \\
40 & 0,710 \\
30 & 0,623 \\
20 & 0,378 \\
\hline
\end{tabular}




$$
\varepsilon_{f}=T_{\alpha} \cdot \log \left(\frac{t}{t_{0}}\right)
$$

onde $\varepsilon_{f}$ é a deformação por fluência do corpo de prova, em $\% ; T_{\alpha}$ representa índice de fluência; $t$ é um valor de tempo arbitrário e $t_{0}$ o tempo final da aplicação do carregamento.

Conforme pode ser observado na Figura 4.2 e na Tabela 4.2, os índices de fluência $\left(\mathrm{T}_{\alpha}\right)$ obtidos apresentaram-se proporcionais e com valores crescentes em função do aumento do nível de carregamento aplicado aos ensaios. A Figura 4.3 apresenta a variação do índice de fluência e das deformações iniciais dos corpos de prova em função dos diferentes níveis de carregamento para os ensaios convencionais de fluência no GTN.

a)

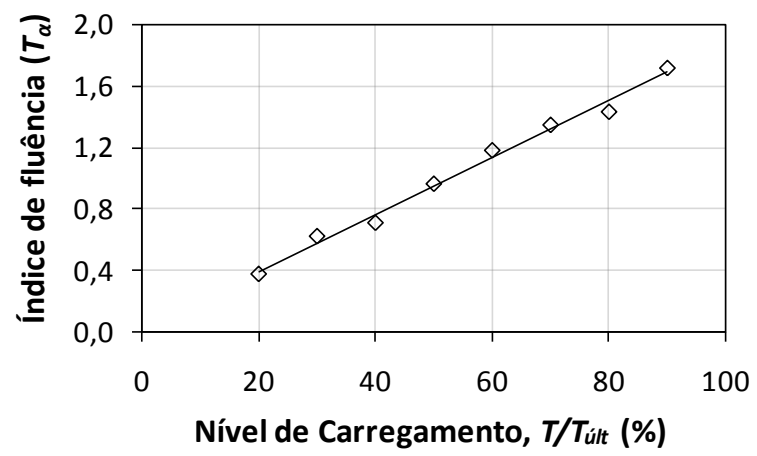

b)

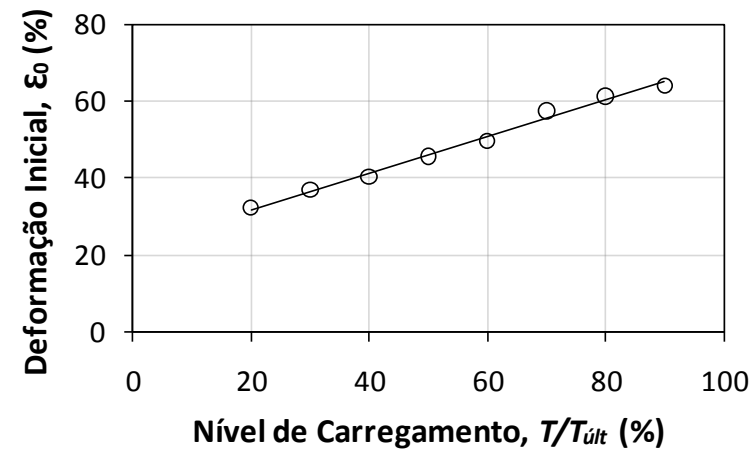

Figura 4.3 - (a) Índice de fluência e (b) deformação inicial dos corpos de prova em função do nível de carregamento aplicado aos ensaios convencionais de fluência conduzidos no GTN.

A regressão linear obtida para o conjunto de dados do índice de fluência $\left(\mathrm{T}_{\alpha}\right)$ é representada pela Equação 15.

$$
T_{\alpha}=0,018 \cdot\left(\frac{T}{T_{\text {últ }}}\right)+0,027
$$

onde $T_{\alpha}$ é o índice de fluência; $\left(\frac{T}{T_{\text {últ }}}\right)$ é o nível de carregamento aplicado, referente a porcentagem da resistência à tração do material. Essa relação levou a um $\mathrm{R}^{2}$ igual a 0,99 .

Com relação à deformação inicial do corpo de prova, obteve-se a seguinte regressão linear (Equação 16).

$$
\varepsilon_{0}=0,474 \cdot\left(\frac{T}{T_{\text {últ }}}\right)+22,438
$$

onde $\varepsilon_{0}$ é a deformação inicial do corpo de prova, em $\% ;\left(\frac{T}{T_{\text {últ }}}\right)$ é o nível de carregamento 
aplicado, referente a porcentagem da resistência à tração do material. O ajuste linear desses dados resultou em um $\mathrm{R}^{2}$ igual a 0,99 .

Observou-se também, que as deformações iniciais dos corpos de prova apresentaram valores crescentes em função do nível de carregamento aplicado. Destaca-se que estes resultados mostraram-se coerentes, pois se deve levar em conta que a aplicação do carregamento destes ensaios foi realizada através de procedimento manual, fator que poderia levar a uma maior variabilidade desses parâmetros.

\subsubsection{Avaliação da influência do confinamento e da temperatura no comportamento em fluência do GTN}

Este item apresenta e discute os resultados dos ensaios conduzidos com o propósito de avaliar a influência do confinamento e da temperatura no comportamento em deformação por fluência do geotêxtil não-tecido de poliéster. Foram realizados e analisados quatro ensaios de fluência, conduzidos no sentido transversal de fabricação do geossintético e com a imposição de diversas condições aos corpos de prova (confinamento e/ou aquecimento). O nível de carregamento empregado nesta avaliação foi de 50\% da resistência à tração desse material. Essa escolha foi baseada devido a este valor encontrar-se entre os outros carregamentos existentes nos ensaios convencionais de fluência realizados. Desta forma, caso o atrito entre as geomembranas e o corpo de prova levasse a uma variação do nível de carregamento maior que a prevista anteriormente (apresentada no item 3.1.4), os resultados dos ensaios conduzidos no equipamento de fluência confinada e acelerada poderiam ser comparados àqueles obtidos nos ensaios convencionais com carregamentos diferentes (e.g. $40 \%$ ou $60 \%$ da resistência à tração).

Utilizando-se como referência o resultado do ensaio de fluência convencional, com nível de carregamento de 50\% da resistência à tração do GTN, primeiramente, executouse um ensaio com o corpo de prova confinado em areia (C), submetido a uma tensão normal de $50 \mathrm{kPa}$ e conduzido à temperatura ambiente. Posteriormente, foi realizado um ensaio de fluência confinada e acelerada (CA), onde se empregou a mesma condição de confinamento imposta ao ensaio anterior, porém com um acréscimo de aproximadamente $12^{\circ} \mathrm{C}$ em relação à temperatura do ensaio confinado (C). Por fim, foi realizado um ensaio de fluência acelerada (A), conduzido em condição de isolamento (não confinado) e com temperatura de 
aproximadamente $36^{\circ} \mathrm{C}$. Para este ensaio, empregou-se o mesmo salto de temperatura utilizado no ensaio confinado e acelerado (CA). A Figura 4.4 apresenta os resultados obtidos nos diferentes ensaios de fluência conduzidos no GTN, onde também são ilustradas as retas de ajuste dos pontos experimentais, cujas equações apresentam a forma da Equação 13.

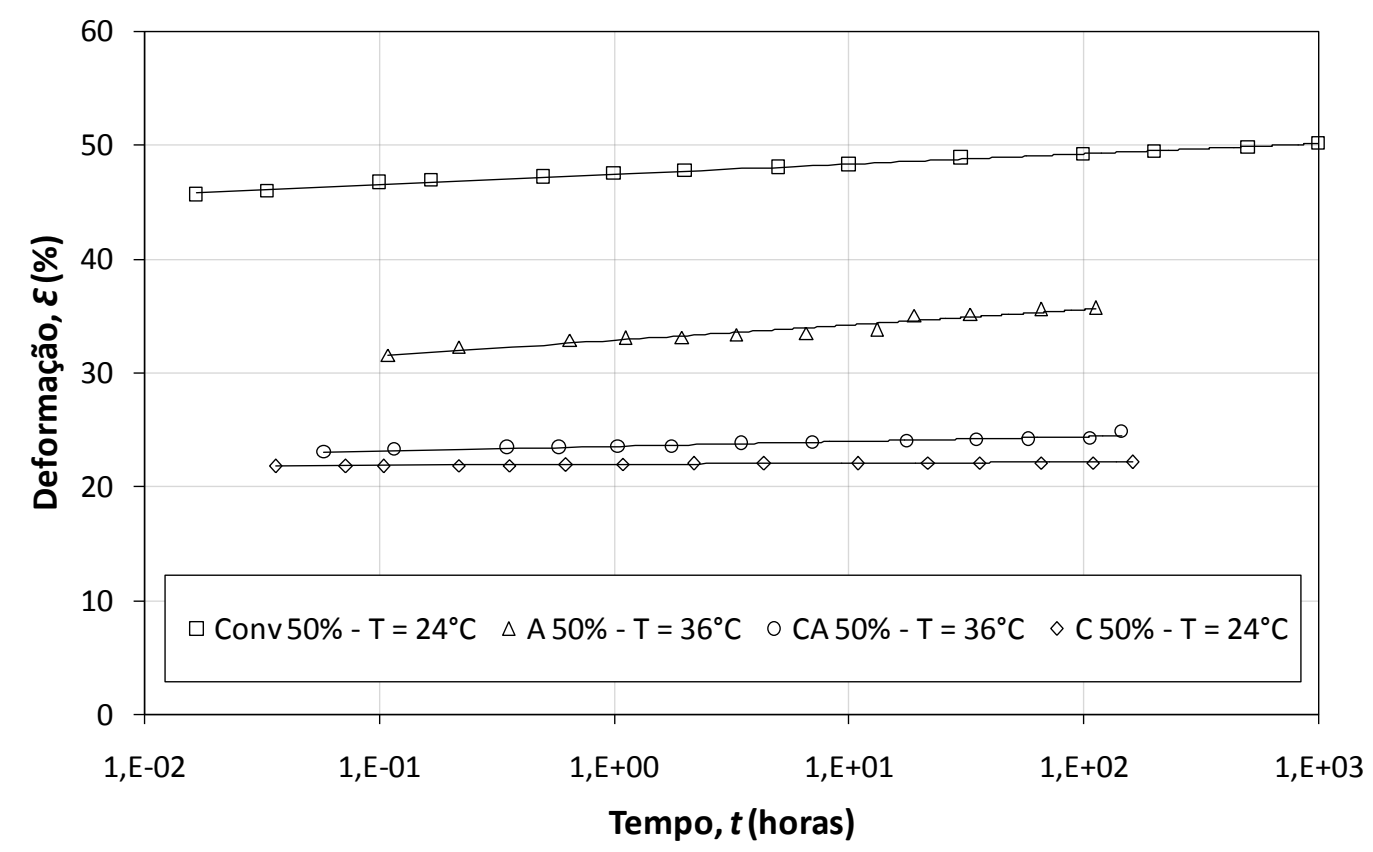

Figura 4.4 - Curvas de fluência dos diferentes ensaios de fluência conduzidos no GTN, com nível de carregamento de $50 \%$ da resistência à tração do geossintético.

A Tabela 4.3 resume os parâmetros obtidos a partir dos ajustes (Equação 13) dos pontos experimentais de cada ensaio.

Tabela 4.3 - Parâmetros obtidos nas curvas de ajuste (Equação 13) dos pontos experimentais dos ensaios conduzidos no GTN.

\begin{tabular}{cccccc}
\hline $\begin{array}{c}\text { Tipo de } \\
\text { ensaio }\end{array}$ & $\begin{array}{c}\text { Temperatura do } \\
\text { ensaio }\left({ }^{\circ} \mathrm{C}\right)\end{array}$ & $\begin{array}{c}\text { Deformação } \\
\text { inicial }(\%)^{2}\end{array}$ & $\mathrm{a}$ & $\mathrm{b}$ & $\mathrm{R}^{2}$ \\
\hline Conv 50\% & 24 & 45,64 & 0,963 & 47,45 & 0,99 \\
A 50\% & 36 & 31,56 & 1,363 & 32,88 & 0,94 \\
CA 50\% & 36 & 23,02 & 0,418 & 23,54 & 0,92 \\
C 50\% & 24 & 21,75 & 0,107 & 21,91 & 0,95 \\
\hline
\end{tabular}

1 - Porcentagem da resistência à tração do material $\left(\mathrm{T} / \mathrm{T}_{\text {últ }}\right)$;

2 - Deformação inicial obtida a partir da análise de cada ensaio. 
Apesar da visível variação das inclinações das curvas de fluência apresentadas na Figura 4.4, a Figura 4.5 mostra os resultados apenas em termos de deformações por fluência. Essa representação permite verificar com maior clareza a influência da temperatura e do confinamento nas deformações por fluência do GTN. Deste modo, a análise foi conduzida por meio da comparação entre os valores do índice de fluência $\left(\mathrm{T}_{\alpha}\right)$. Salienta-se que apesar de apenas alguns pontos serem plotados, os índices de fluência foram calculados considerando todo o conjunto de dados de cada ensaio.

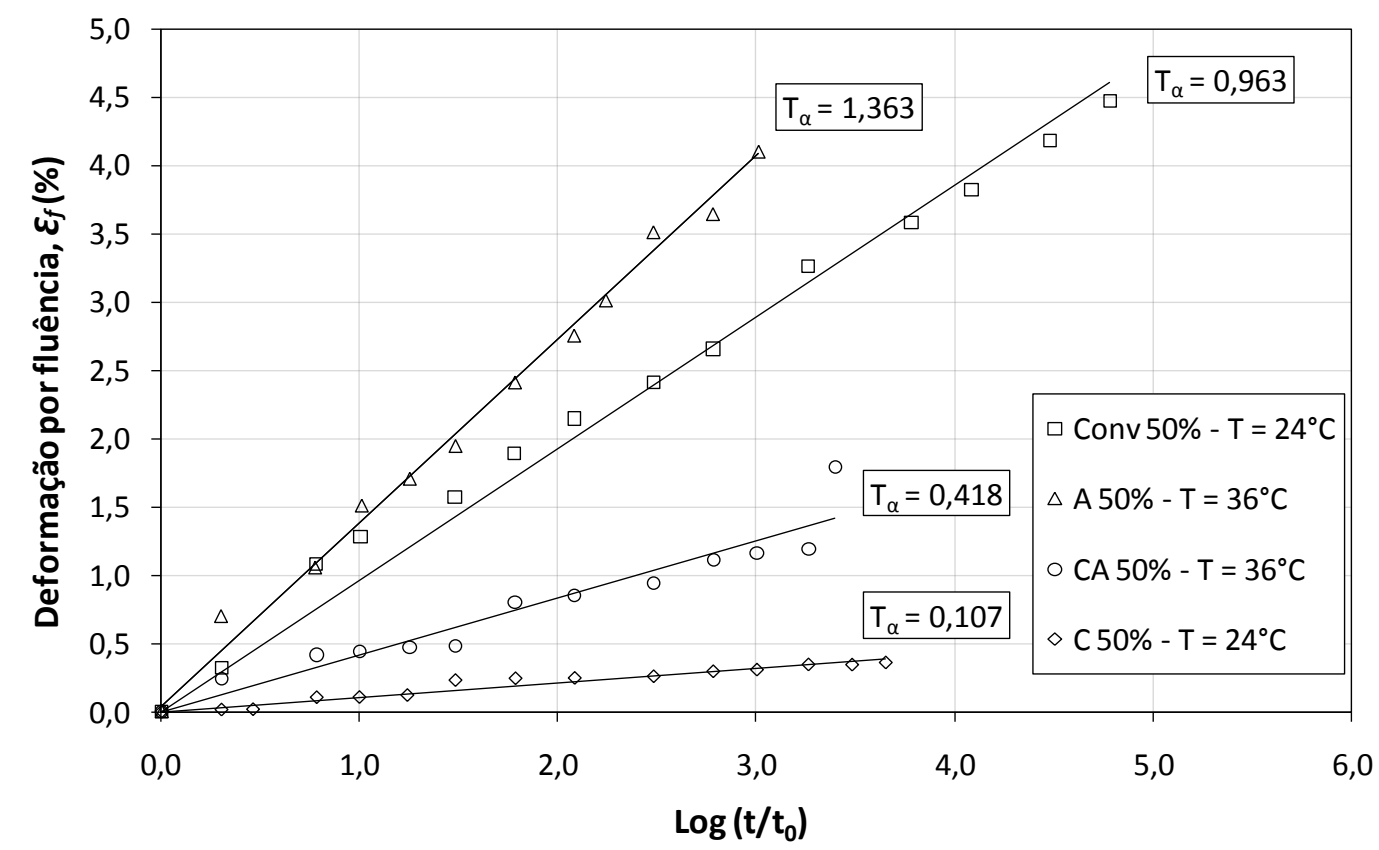

Figura 4.5 - Deformações por fluência dos diferentes ensaios de fluência conduzidos no GTN, com carregamento de $50 \%$ da resistência à tração desse material.

A Tabela 4.4 resume os índices de fluência obtidos com base na Equação 14.

Tabela 4.4 - Índice de fluência obtidos nos ensaios de fluência conduzidos no GTN com nível de carregamento de 50\% da resistência à tração desse geossintético.

\begin{tabular}{ccc}
\hline Tipo de ensaio & $\begin{array}{c}\text { Temperatura do } \\
\text { ensaio }\left({ }^{\circ} \mathrm{C}\right)\end{array}$ & Índice de fluência, $T_{\alpha}$ \\
\hline Conv 50\% & 24 & 0,963 \\
A 50\% & 36 & 1,363 \\
CA 50\% & 36 & 0,418 \\
C 50\% & 24 & 0,107 \\
\hline
\end{tabular}

1 - Porcentagem da resistência à tração do material $\left(\mathrm{T} / \mathrm{T}_{\text {últ }}\right)$. 
Nota-se que os valores dos índices de fluência apresentados na Figura 4.5 e na Tabela 4.4 dependem das condições impostas aos ensaios. Percebe-se que o confinamento em areia com tensão de normal de $50 \mathrm{kPa}$ foi responsável por uma redução expressiva no índice de fluência, resultando em um valor igual a 0,107. Assim, comparando-se esse valor ao índice de fluência do ensaio de fluência convencional (0,963), obteve-se uma redução de aproximadamente $89 \%$.

Outro fator que pode ser destacado é o efeito do confinamento para os ensaios conduzidos em temperatura elevada, pois, os índices de fluência dos ensaios confinado e acelerado $(0,418)$ e acelerado $(1,363)$, resultaram em uma redução de aproximadamente $69 \%$ devido ao confinamento. Nota-se que a diminuição do índice de fluência devido ao confinamento em areia foi menor em temperatura elevada, do que em temperatura ambiente (89\%). Este fator se deve ao efeito da temperatura no comportamento em deformação por fluência dos geossintéticos.

A influência da temperatura no ensaio de fluência também foi observada nos ensaios conduzidos em isolamento (não confinado). Desta forma, verificou-se que a elevação da temperatura do ensaio causou um aumento no índice de fluência do material em ambas as condições de ensaio (isolamento e em meio confinado).

Portanto, a partir dos resultados apresentados e discutidos, verificou-se que tanto o confinamento em areia, quanto da elevação de temperatura do ensaio influenciaram o comportamento em deformação por fluência deste geossintético. Esses resultados vão ao encontro dos apresentados na literatura técnica (MCGOWN et al., 1982; COSTA, 1999; COSTA, 2004; KAMIJI et al., 2008; FRANÇA, 2012), no qual, as deformações por fluência do geotêxtil não-tecido são influenciadas pelo confinamento em solo (item 2.3.5) e devido à elevação da temperatura de ensaio (BARAS, 2001; BARAS et al., 2002; COSTANZI, 2003; COSTANZI et al., 2003; ZORNBERG et al., 2004), conforme descrito no item 2.3.4.

Além disso, os valores encontrados nesta pesquisa foram comparados aos apresentados por França (2012). Este autor avaliou o comportamento em fluência de um geotêxtil não-tecido de filamento contínuo de poliéster (resistência igual a 13,87 kN/m e deformação na ruptura de 59,57\% no sentido transversal do material; espessura nominal de 2,356 mm; gramatura de 253,6 g/ $/ \mathrm{m}^{2}$ ) submetido ao confinamento em areia (tensão normal de $50 \mathrm{kPa})$ e elevação de temperatura $\left(38^{\circ} \mathrm{C}\right)$. A Tabela 4.5 apresenta o efeito do confinamento em areia (em temperatura ambiente e elevada) para os ensaios conduzidos no geotêxtil 
empregado nesta pesquisa, juntamente com o avaliado por França (2012). Esses valores representam em porcentagem, a redução da taxa de deformação por fluência devido ao confinamento em areia, para os ensaios confinado (C) e convencional (Conv), bem como para o confinado e acelerado (CA) e apenas acelerado (A).

Tabela 4.5 - Comparativo entre os resultados obtidos nesta pesquisa e por França (2012).

\begin{tabular}{lcc}
\hline \multirow{2}{*}{$\begin{array}{c}\text { Tipo de } \\
\text { Geossintéticos }\end{array}$} & \multicolumn{2}{c}{ Efeito do confinamento em areia com tensão normal de $50 \mathrm{kPa}^{3}$} \\
\cline { 2 - 3 } & $89 \%$ & CA e A \\
\hline GTN $^{1}$ & $85 \%$ & $69 \%$ \\
França $(2012)^{2}$ & $67 \%^{4}$ \\
\hline $1-$ Resultados discutidos no item $4.1 .1-$ GTN fibra curta; \\
$2-$ Análise realizada com os dados de França (2012) - GTN filamento contínuo; \\
3 - Comparação entre os índices de fluência de cada ensaio; \\
$4-$ Ensaios realizados com temperatura de $38^{\circ} \mathrm{C}$.
\end{tabular}

Nota-se uma coerência entre os valores ilustrados na Tabela 4.5. Desta forma, o efeito do confinamento, tanto para os ensaios conduzidos em temperatura ambiente $(\mathrm{C}$ e Conv) quanto em temperatura elevada (CA e A), apresentou a mesma ordem de grandeza. Salienta-se que a pequena diferença entre os resultados pode ser atribuída a configuração do geotêxtil não-tecido utilizado por França (2012), que apresenta filamentos contínuos, diferentemente do geotêxtil não-tecido de fibra curta empregado nesta pesquisa. No entanto, França (2012) mostrou que o confinamento em areia é responsável por uma redução similar no índice de fluência para os dois tipos de geotêxteis não-tecidos (fibras curtas e filamento contínuo), e que são proporcionais às tensões normais empregadas nos ensaios confinados. Além disso, houve uma diferença entre a temperatura dos ensaios, sendo de $36^{\circ} \mathrm{C}$ e $38^{\circ} \mathrm{C}$, para o geotêxtil não-tecido utilizado nesta pesquisa e o utilizado por França (2012), respectivamente. Desta forma, pode-se afirmar que a comparação realizada através dos valores ilustrados na Tabela 4.5 apresenta-se coerente.

Por outro lado, as curvas de fluência apresentadas na Figura 4.4 indicam que as deformações iniciais dos corpos de prova sofrem variação devido às diferentes condições impostas aos ensaios de fluência. A Figura 4.6 apresenta separadamente os valores das deformações iniciais encontradas para cada ensaio de fluência conduzido no GTN. 


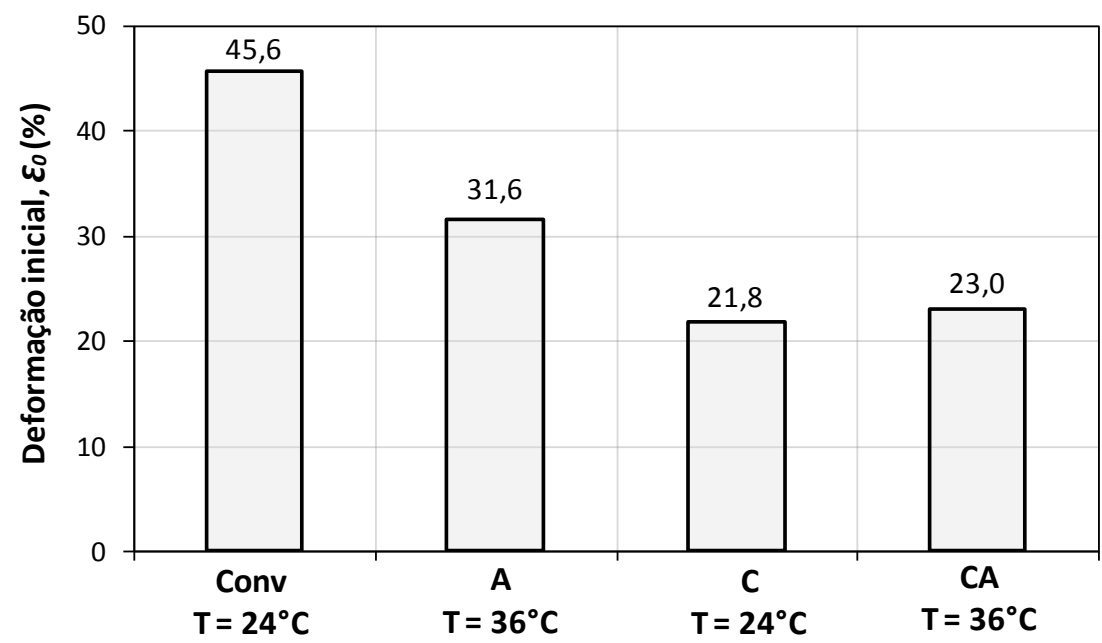

Figura 4.6 - Deformações iniciais dos corpos de prova empregados nos ensaios de fluência conduzidos no GTN, para o nível de carregamento de 50\% da resistência à tração desse geossintético.

Observa-se na Figura 4.6 que o confinamento em solo provocou uma redução na deformação inicial do corpo de prova dos ensaios realizados em temperatura ambiente (convencional e confinado). Entretanto, o efeito da temperatura não foi observado para os ensaios conduzidos em isolamento (convencional e acelerado). Isto se deve ao método de aplicação do carregamento da solicitação de tração, visto que para o ensaio convencional (executado em cavaletes metálicos), esse procedimento é realizado manualmente. Já para o ensaio acelerado (conduzido no equipamento de fluência confinada e acelerada), emprega-se o novo acessório (descrito no item 3.1.7) para efetuar o carregamento dos pesos livres. Portanto, a influência da temperatura e do confinamento em areia foi avaliada apenas através das deformações iniciais dos corpos de prova dos ensaios A, C e CA (realizados no equipamento de fluência confinada e acelerada). Assim, o efeito do confinamento é ilustrado pela diferença entre os valores das deformações iniciais de $23 \%$ e $31,6 \%$, dos ensaios confinado e acelerado (CA) e acelerado (A), respectivamente. Já o efeito da temperatura pelos valores dos ensaios confinado e acelerado (23\%) e confinado $(21,8 \%)$.

A execução de ensaios em temperatura elevada (A e CA) possibilitou a construção das curvas mestras de fluência do GTN em condição de isolamento e confinamento em areia (tensão normal de $50 \mathrm{kPa}$ ). A Figura 4.7 ilustra as curvas mestras obtidas para o geotêxtil nãotecido de poliéster utilizado nesta pesquisa. As retas apresentadas foram obtidas a partir de 
regressão logarítmica dos dados de cada curva mestra, cujas equações são expressas na Figura 4.7 e apresentam a forma da Equação 13.

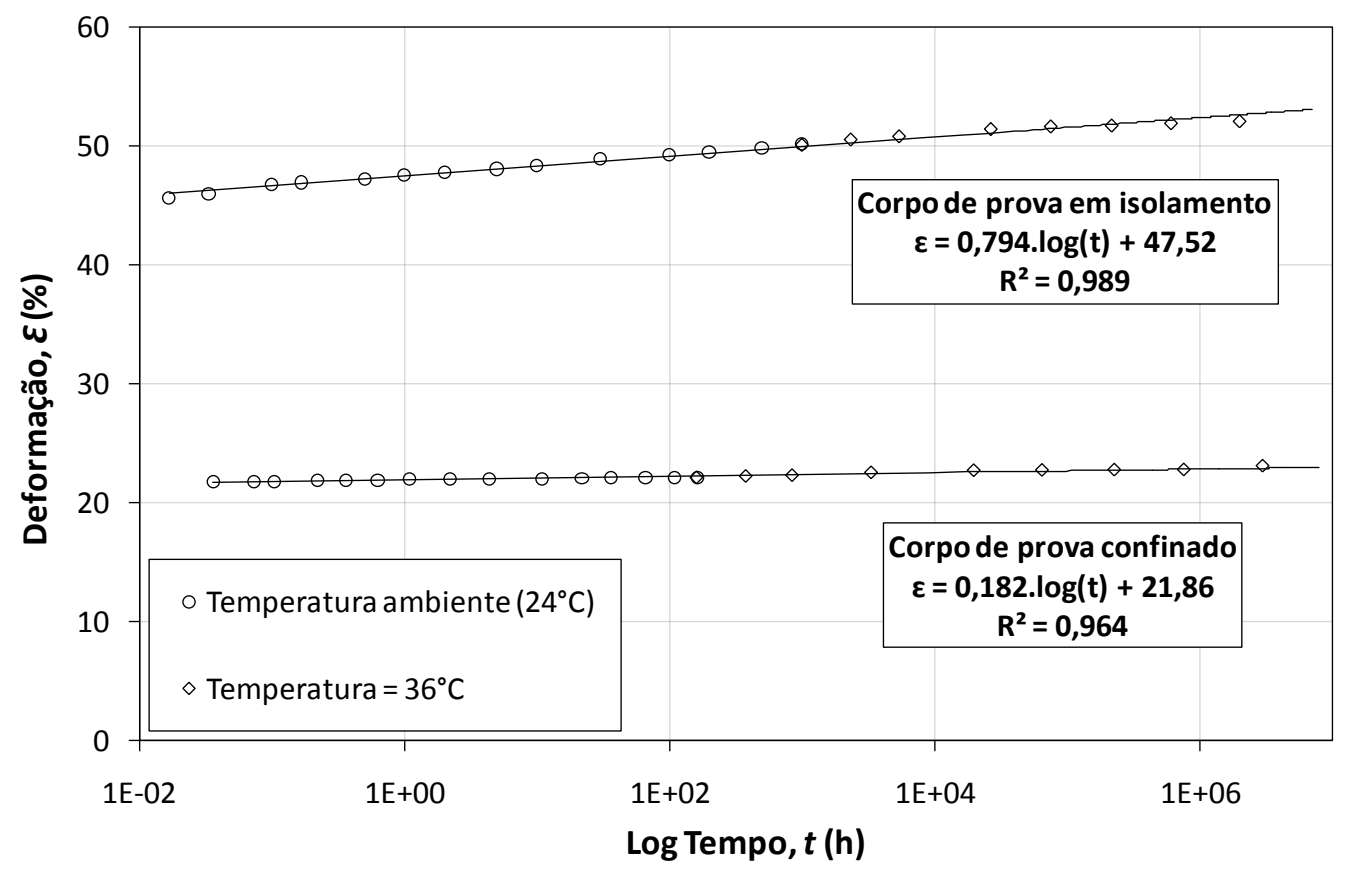

Figura 4.7 - Curvas mestras de fluência do GTN em condição de isolamento e em confinamento em areia, para o nível de carregamento de 50\% da resistência à tração desse geossintético.

A comparação entre as curvas mestras obtidas a partir da série de ensaios conduzidos no GTN indica o efeito do confinamento no comportamento em deformação por fluência desse material. Esta influência é apresentada pela diferença entre inclinação das retas obtidas pela regressão logarítmica dos dados. Deste modo, houve uma redução de aproximadamente $77 \%$ na taxa de deformações por fluência, quando o corpo de prova é submetido ao confinamento em areia com tensão normal de $50 \mathrm{kPa}$. Nota-se que este valor foi menor que a redução apresentada na avaliação de cada ensaio isoladamente (aproximadamente 89\%). Porém, deve-se levar em conta o período na qual as deformações por fluência são analisadas, ou seja, as curvas mestras apresentam o comportamento da fluência por até 340 anos. Deste modo, este valor representa a influência do confinamento em longo prazo para as deformações por fluência. A Tabela 4.6 resume as características das curvas mestras de fluência ilustradas na Figura 4.7. 
Tabela 4.6 - Características das curvas mestras de fluência para as condições de isolamento e confinamento (ensaios GTN).

\begin{tabular}{ccccc}
\hline $\begin{array}{c}\text { Condição do } \\
\text { ensaio }\end{array}$ & $\begin{array}{c}\text { Nomenclatura do } \\
\text { ensaio }\end{array}$ & $\begin{array}{c}\text { Duração total de } \\
\text { ensaio (h) }\end{array}$ & $\begin{array}{c}\text { Deformação inicial } \\
\text { do ensaio (\%) }\end{array}$ & $\begin{array}{c}\text { Deformação final } \\
\text { do ensaio (\%) }\end{array}$ \\
\hline Isolamento & Curva Mestra 50\% & $2,01 \mathrm{E}+06$ & 45,65 & 52,05 \\
Confinado & Curva Mestra 50\% & $2,97 \mathrm{E}+06$ & 21,75 & 23,11 \\
\hline
\end{tabular}

1 - Condição da curva mestra de fluência;

2 - Duração total do ensaio interpretada na temperatura de referência (ambiente).

De acordo com os valores apresentados na Tabela 4.6, verifica-se também a diferença entre as deformações iniciais, com valores de 45,65\% e 21,75\% para as condições em isolamento e confinamento em areia, respectivamente, que resultaram numa redução de aproximadamente $52 \%$ na deformação inicial.

\subsubsection{Avaliação do comportamento na ruptura por fluência para condição confinada do GTN}

Os ensaios relatados e discutidos neste item tiveram por objetivo a determinação do comportamento na ruptura por fluência do geotêxtil não-tecido de poliéster quando confinado em areia. O parâmetro avaliado foi o tempo necessário para que ocorresse a ruptura por fluência desse geossintético. Inicialmente foi prevista uma série de ensaios de ruptura por fluência (carregamentos elevados em relação à resistência à tração do material) com níveis de carregamento entre 90 e 70\%, subdivididos em dois grupos (ensaios apenas confinados e ensaios confinados e acelerados). Entretanto, conforme descrito no item 3.5, a gramatura dos corpos de prova levou a níveis de carregamento diferentes dos valores nominais previstos (apresentados na Tabela 3.4). No entanto, para estes ensaios são necessários apenas o conhecimento do nível de carregamento e o tempo para que ocorra a ruptura por fluência do corpo de prova. Desta forma, adotaram-se por nível de carregamento nominal os valores dos carregamentos reais obtidos (após correção) nos ensaios confinados (C). Assim, foi possível estabelecer a relação entre esse parâmetro e o tempo de ruptura através da curva de ruptura por fluência.

Primeiramente foram executados os ensaios apenas em condição de confinamento, 
conduzidos a temperatura ambiente (aproximadamente igual a $24 \pm 0,2^{\circ} \mathrm{C}$ ) e carregamento entre 95 e $70 \%$ da resistência à tração do material. A Figura 4.8 apresenta as curvas de fluência obtidas com o geotêxtil não-tecido. $\mathrm{O}$ ajuste dos pontos experimentais foi realizado a partir de regressão logarítmica, resultando em uma relação conforme indicado na Equação 13.

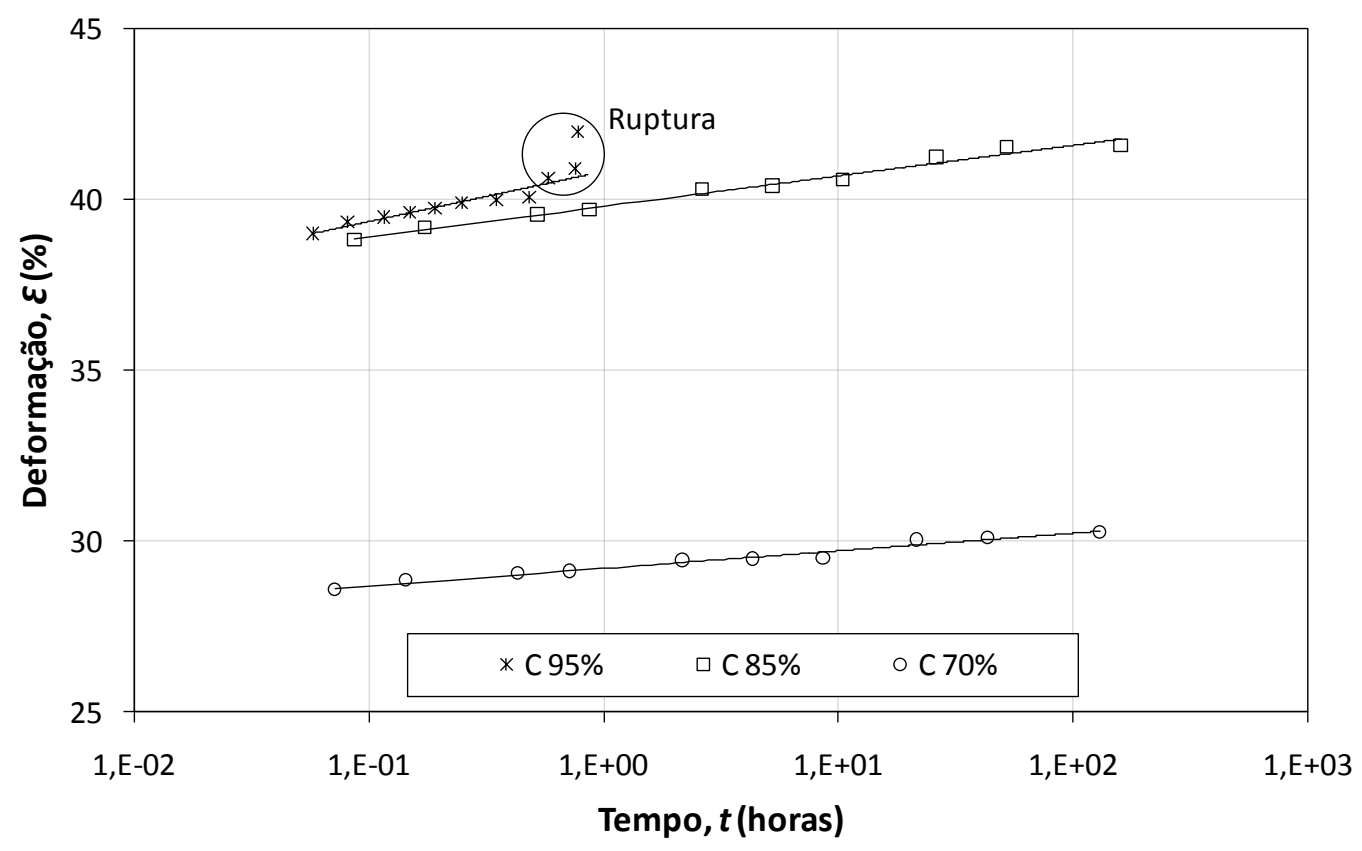

Figura 4.8 - Curvas de fluência do GTN obtidas com os corpos de prova em condição confinada e em temperatura ambiente, para os níveis de carregamento entre 95 e $70 \%$ da resistência à tração desse material.

A Tabela 4.7 resume os parâmetros obtidos em cada reta de ajuste, de acordo com a Equação 13.

Tabela 4.7 - Parâmetros obtidos a partir das regressões logarítmicas (Equação 13) dos ensaios conduzidos no GTN.

\begin{tabular}{cccccc} 
Tipo de ensaio $^{1}$ & $\begin{array}{c}\text { Temperatura do } \\
\text { ensaio }\left({ }^{\circ} \mathrm{C}\right)\end{array}$ & $\begin{array}{c}\text { Deformação inicial } \\
(\%)^{2}\end{array}$ & $\mathrm{a}$ & $\mathrm{b}$ & $\mathrm{R}^{2}$ \\
\hline C 95\% & 24 & 38,99 & 1,485 & 40,82 & 0,93 \\
C $85 \%$ & 24 & 38,82 & 0,914 & 39,81 & 0,98 \\
C 70\% & 24 & 28,56 & 0,539 & 29,20 & 0,97 \\
\hline
\end{tabular}

1 - Porcentagem da resistência à tração do material (T/Túlt);

2 - Deformação inicial obtida a partir da análise de cada ensaio. 
Conforme se pode observar na Figura 4.8, nesta condição, apenas o ensaio com carregamento igual a 95\% da resistência à tração atingiu ruptura em menos de 100 horas de ensaio (0,71 horas). Salienta-se que, o tempo de ruptura por fluência foi tomado de acordo com o sugerido pelas NBR 15.226 e ASTM D 5262, ou seja, representa o tempo transcorrido desde o final da aplicação do carregamento de ensaio até o momento da ruptura por fluência do corpo de prova.

Em seguida, conduziram-se ensaios confinados e acelerado (CA) para os níveis de carregamento de 85 e $70 \%$ da resistência à tração do material. Esses ensaios foram executados com a mesma condição de confinamento (tensão normal de $50 \mathrm{kPa}$ ), porém em temperatura elevada. $\mathrm{O}$ aumento da temperatura desses ensaios teve por objetivo a diminuição do tempo necessário para que ocorresse a ruptura por fluência do material. A Figura 4.9 apresenta as curvas de fluência obtidas nos ensaios confinado e acelerado (CA) e apenas confinado (C) para o nível de carregamento igual a $85 \%$ da resistência à tração.

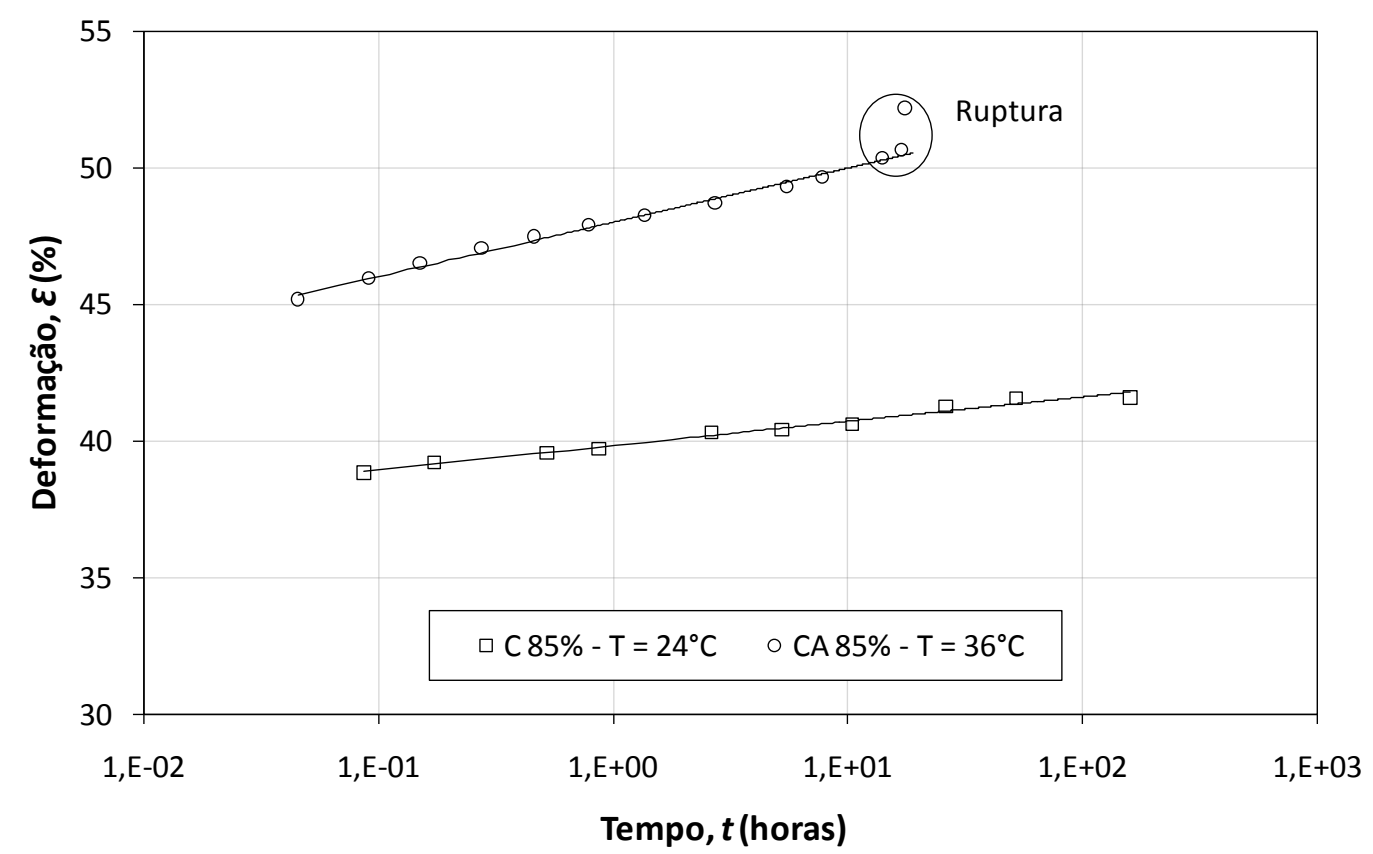

Figura 4.9 - Curvas de fluência dos ensaios confinado e acelerado (CA) e apenas confinado (C) conduzidos no geotêxtil não-tecido.

A Tabela 4.8 apresenta os resultados obtidos nas curvas de ajuste dos dados de cada ensaio, que apresentam a forma da Equação 13. 
Tabela 4.8 - Parâmetros obtidos pelas regressões logarítmicas (Equação 13) a partir dos ensaios conduzidos com carregamento igual a 85\% da resistência à tração do GTN.

\begin{tabular}{cccccc}
\hline Tipo de ensaio $^{1}$ & $\begin{array}{c}\text { Temperatura do } \\
\text { ensaio }\left({ }^{\circ} \mathrm{C}\right)\end{array}$ & $\begin{array}{c}\text { Deformação inicial } \\
(\%)^{2}\end{array}$ & a & b & $\mathrm{R}^{2}$ \\
\hline C $85 \%$ & 24 & 38,82 & 0,914 & 39,81 & 0,98 \\
CA $85 \%$ & 36 & 45,17 & 2,081 & 48,01 & 0,99 \\
\hline
\end{tabular}

1 - Porcentagem da resistência à tração do material (T/T útt $_{\text {, }}$;

2 - Deformação inicial obtida a partir da análise de cada ensaio.

Nota-se na Figura 4.9 que o ensaio confinado e acelerado (CA) levou o corpo de prova de GNT à ruptura por fluência, com tempo igual a 18,1 horas após o carregamento (terceira fase da fluência). Observa-se ainda, que o acréscimo de temperatura foi responsável por um aumento na deformação inicial do corpo de prova e na taxa de deformação por fluência (expressa pela inclinação da curva de regressão logarítmica dos dados do ensaio). A Figura 4.10 apresenta as curvas de fluência obtidas nos ensaios de fluência confinada e acelerada $(\mathrm{CA})$ e apenas confinado $(\mathrm{C})$, para o carregamento de $70 \%$ da resistência à tração do GTN.

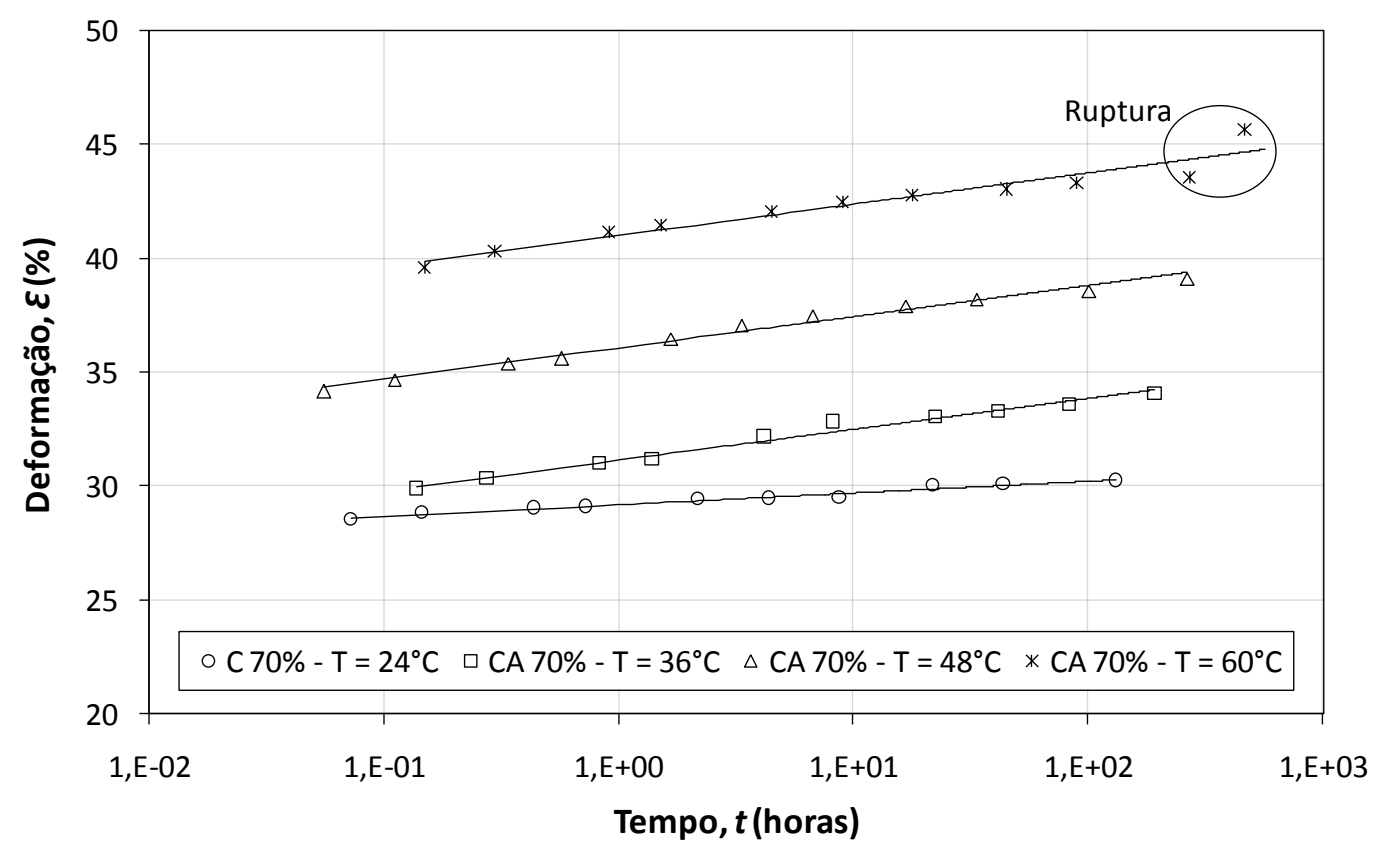

Figura 4.10 - Curvas de fluência obtidas nos ensaios confinado e acelerado (CA) e apenas confinado $(\mathrm{C})$, para carregamento de $70 \%$ da resistência à tração do GTN. 
As curvas obtidas por regressão logarítmica dos dados de cada ensaio apresentam a forma indicada na Equação 13 e seus parâmetros estão ilustrados na Tabela 4.9.

Tabela 4.9 - Parâmetros obtidos a partir das regressões logarítmicas (Equação 13) dos dados experimentais dos ensaios conduzidos com carregamento de $70 \%$ da resistência à tração do GTN.

\begin{tabular}{cccccc}
\hline Tipo de ensaio $^{1}$ & $\begin{array}{c}\text { Temperatura do } \\
\text { ensaio }\left({ }^{\circ} \mathrm{C}\right)\end{array}$ & $\begin{array}{c}\text { Deformação } \\
\text { inicial }(\%)^{2}\end{array}$ & $\mathrm{a}$ & $\mathrm{b}$ & $\mathrm{R}^{2}$ \\
\hline C 70\% & 24 & 28,56 & 0,539 & 29,20 & 0,97 \\
CA 70\% & 36 & 29,90 & 1,389 & 31,15 & 0,98 \\
CA 70\% & 48 & 34,15 & 1,444 & 36,05 & 0,98 \\
CA 70\% & 60 & 39,57 & 1,499 & 41,00 & 0,93 \\
\hline
\end{tabular}

1 - Porcentagem da resistência à tração do material $\left(\mathrm{T} / \mathrm{T}_{\text {útt }}\right)$;

2 - Deformação inicial obtida a partir da análise de cada ensaio.

Conforme se observa na Figura 4.10, o ensaio confinado e acelerado (CA) com temperatura de $60^{\circ} \mathrm{C}$ levou o corpo de prova de GTN à ruptura, com tempo de 464,33 horas. Os demais ensaios confinados e acelerados (que precederam a ruptura) foram conduzidos no máximo até 266 horas de duração, onde não se observaram indícios de ruptura do corpo de prova (terceira fase da fluência). Nota-se que o acréscimo de temperatura influencia a deformação por fluência do GTN, bem como as deformações iniciais dos corpos de prova. A Tabela 4.10 sumariza as principais características dos ensaios de fluência conduzidos com o geotêxtil não-tecido.

Tabela 4.10 - Características dos ensaios conduzidos com o GTN.

\begin{tabular}{cccccc}
\hline Ensaio & $\begin{array}{c}\text { Temperatura } \\
\text { do ensaio }\left({ }^{\circ} \mathrm{C}\right)\end{array}$ & $\begin{array}{c}\text { Tempo total } \\
\text { do ensaio (h) }\end{array}$ & $\begin{array}{c}\text { Tempo de ruptura } \\
\text { por fluência }(\mathrm{h})^{2}\end{array}$ & $\begin{array}{c}\text { Deformação } \\
\text { final }(\%)\end{array}$ & $\begin{array}{c}\text { Índice de } \\
\text { fluência, } T_{\alpha}\end{array}$ \\
\hline C 95\% ${ }^{1}$ & 24 & 0,77 & 0,71 & $41,97^{* 3}$ & 1,485 \\
C 85\% & 24 & 160,87 & - & 41,56 & 0,914 \\
CA 85\% ${ }^{1}$ & 36 & 18,12 & 18,10 & $52,17^{* 3}$ & 2,081 \\
C 70\% & 24 & 137,36 & - & 30,26 & 0,539 \\
CA 70\% & 36 & 191,66 & - & 34,07 & 1,389 \\
CA 70\% & 48 & 265,34 & - & 39,11 & 1,444 \\
CA 70\% ${ }^{1}$ & 60 & 464,33 & 464,33 & $45,65^{* 3}$ & 1,499 \\
\hline
\end{tabular}

1 - Ensaio no qual ocorreu ruptura por fluência;

2 - Tempo de ruptura por fluência (após carregamento da solicitação de tração);

$*^{3}$ - Deformação dos corpos de prova na ruptura por fluência. 
Os ensaios confinados conduzidos em temperatura elevada permitiram a construção das curvas mestras de fluência para o GTN, em condição de confinamento em areia. Para a confecção destas curvas, foram seguidos os procedimentos descritos no item 3.5. Assim, estes ensaios foram interpretados segundo o conceito do fator de translação e desta forma, obtendo-se o comportamento em deformação por fluência caso tivessem ocorrido em temperatura ambiente (referência). A Figura 4.11 apresenta as curvas mestras e as retas ajustadas por regressão logarítmica, cuja forma é apresentada pela Equação 13.

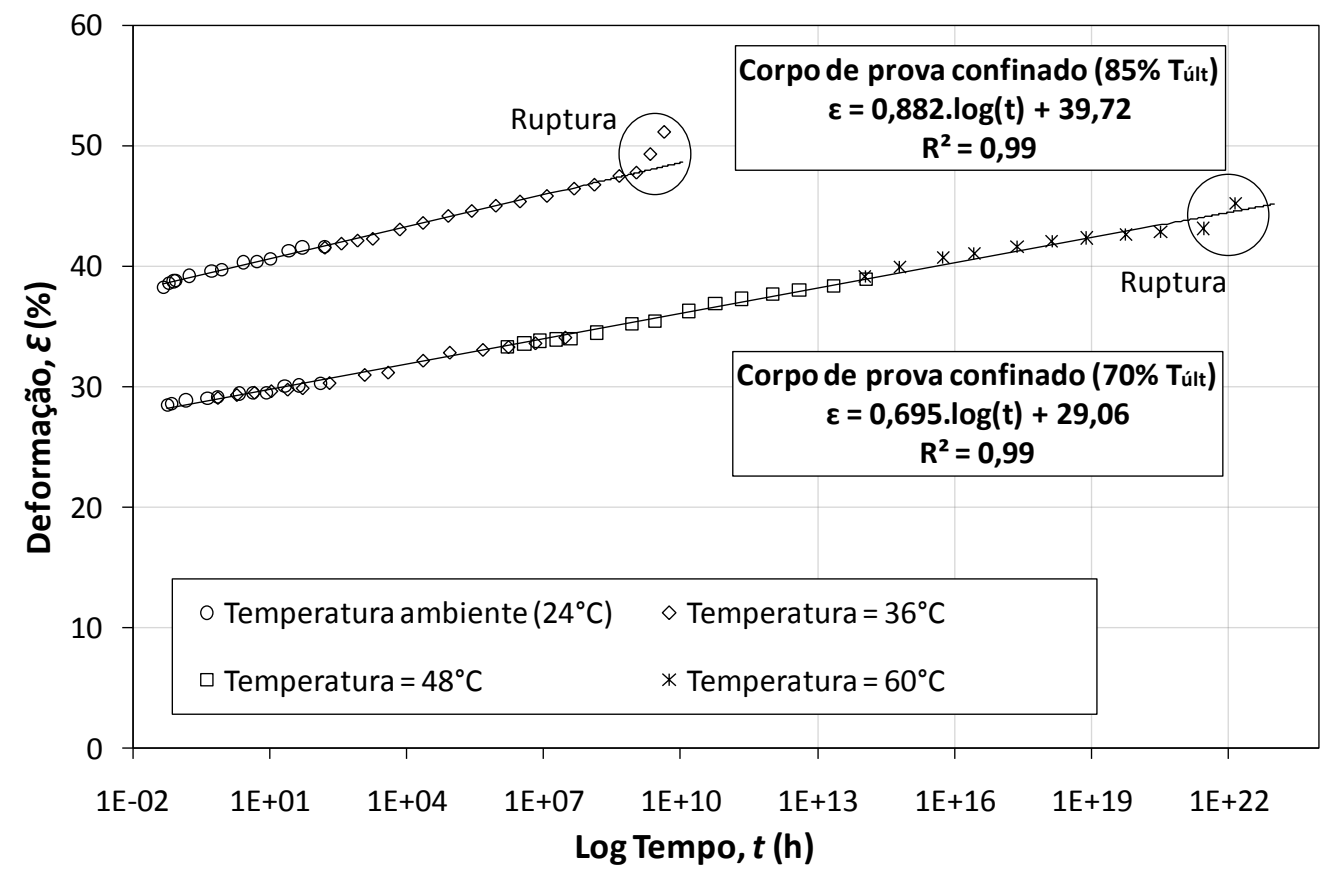

Figura 4.11 - Curvas mestras de fluência do GTN em condição de confinamento em areia e com tensão normal de $50 \mathrm{kPa}$, para os corpos de prova submetidos a carregamento de 85 e $70 \%$ da resistência à tração do material $\left(\mathrm{T}_{\text {últ }}\right)$.

Os resultados obtidos na construção das curvas mestras de fluência apresentaram um ajuste logarítmico satisfatório, com $\mathrm{R}^{2}$ de 0,99 para ambos os níveis de carregamentos. As interpretações dessas curvas levaram aos tempos de ruptura por fluência para os seus respectivos níveis de carregamento. Observou-se que os corpos de prova utilizados nos ensaios de ruptura por fluência em condição confinada apresentaram fluência terciária (apresentado na Figura 4.11), ocasionando a ruptura do material. A Tabela 4.11 resume os valores dos tempos de ruptura por fluência encontrados nos ensaios conduzidos no GTN. 
Tabela 4.11 - Tempo de ruptura por fluência obtido em cada nível de carregamento dos ensaios conduzidos no GTN.

\begin{tabular}{cccc}
\hline Tipo de ensaio & Ensaio & $\begin{array}{c}\text { Tempo de ruptura por } \\
\text { fluência (h) }\end{array}$ & $\begin{array}{c}\text { Deformação na } \\
\text { ruptura (\%) }\end{array}$ \\
\hline $\mathrm{C}$ & C 95\% & $7,10 \mathrm{E}-01$ & 41,97 \\
$\mathrm{C} \mathrm{e} \mathrm{CA}{ }^{1}$ & Curva Mestra 85\% & $4,52 \mathrm{E}+09$ & 51,14 \\
$\mathrm{C} \mathrm{e} \mathrm{CA}^{1}$ & Curva Mestra 70\% & $1,51 \mathrm{E}+22$ & 45,19 \\
\hline
\end{tabular}

1 - Composição das curvas de fluência (método descrito no item 2.4.2);

Os resultados apresentados nesta série de ensaios (sintetizados na Tabela 4.11) possibilitaram a construção da curva de ruptura por fluência do GTN para a condição de confinamento em areia (tensão normal de $50 \mathrm{kPa}$ ). A Figura 4.12 ilustra a curva de ruptura por fluência obtida através do conjunto de ensaios de ruptura por fluência conduzidos no GTN.

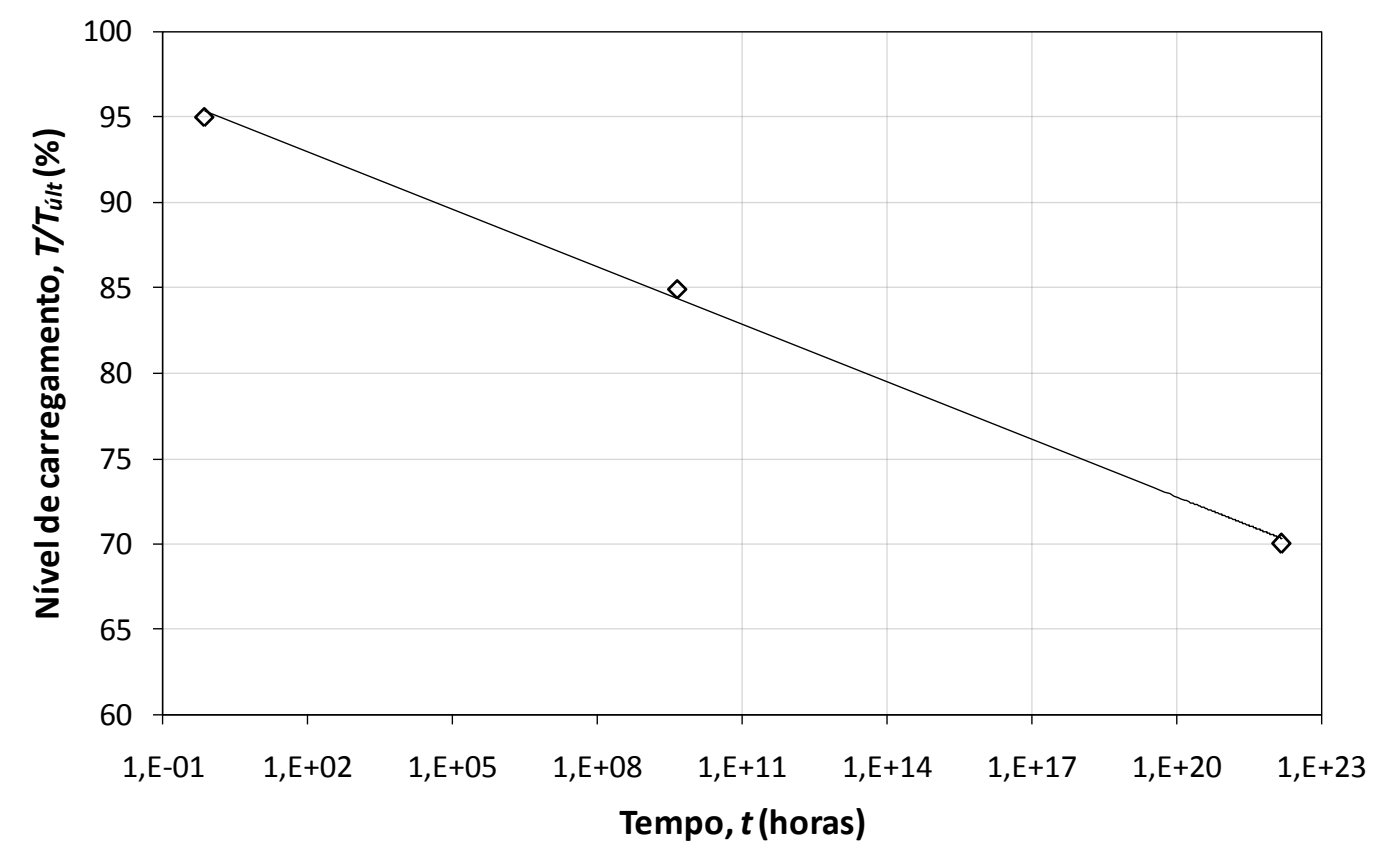

Figura 4.12 - Curva de ruptura por fluência do GTN obtida com corpos de prova em condição de confinamento em areia e tensão normal de $50 \mathrm{kPa}$.

Foi proposto um ajuste por regressão logarítmica dos pontos apresentados na Figura 4.12, o que levou a uma relação conforme indicado na Equação 17, a seguir. 


$$
\frac{T}{T_{\text {últ }}}=-1,124 \cdot \log (t)+95,179
$$

onde $\frac{T}{T_{\text {últ }}}$ é o nível de carregamento aplicado, referente a porcentagem da resistência à tração do material, em \%; $t$ é o tempo de ruptura por fluência do geossintético, em horas. O ajuste por regressão logarítmica desses dados resultou em um $\mathrm{R}^{2}$ igual a 0,98 .

Conforme apresentado no item 2.5, os efeitos indesejáveis da fluência em estruturas de solo reforçado são considerados por meio de um fator de redução devido à fluência. Este fator desempenha um papel importante na determinação da resistência à tração empregada no dimensionamento deste tipo de estruturas. $\mathrm{O}$ valor deste parâmetro pode ser determinado a partir de referência da literatura ou por meio de ensaios de fluência. Para o primeiro caso, empregam-se valores conforme apresentados na Tabela 2.1 (KOERNER, 2005; VERTEMATTI, 2004; FEDERAL HIGHWAY ADMINISTRATION, 2001). No segundo caso, são utilizados os resultados dos ensaios de ruptura por fluência, onde se emprega a representação da curva de ruptura por fluência do geossintético (construção da curva conforme ilustrado na Figura 2.8) para determinar o valor do fator de redução devido à fluência. Deste modo, a partir da curva de ruptura por fluência do geossintético a ser empregado em uma obra de solo reforçado, juntamente com o tempo (t) de vida útil dessa respectiva obra, é possível determinar a solicitação máxima ( $\left.\mathrm{T}_{\text {fluência }}\right)$ que pode ser aplicada ao geossintético. Quando expresso em relação a resistência à tração do geossintético $\left(\mathrm{T} / \mathrm{T}_{\text {últ }}\right)$, o inverso deste valor resulta no fator de redução devido à fluência para esse tipo de geossintético. Este procedimento é ilustrado na Figura 2.28. No entanto, salienta-se que ambos os procedimentos descritos anteriormente, levam em consideração o geossintético apenas em condição de isolamento (não confinado).

Desta forma, caso o geotêxtil não tecido de poliéster (GTN) avaliado nesta pesquisa fosse empregado em um projeto de um muro reforçado, para uma vida útil de projeto entre 75 e 100 anos (FEDERAL HIGHWAY ADMINISTRATION, 2001), a interpretação da curva de ruptura por fluência desse material, na condição de confinamento em areia e com tensão normal de $50 \mathrm{kPa}$ (Figura 4.12) resultaria em um fator de redução devido à fluência igual a 1,13 (para a solicitação máxima de 88,5\% da resistência à tração desse geossintético). Assim, levando-se em conta os valores do fator de redução devido à fluência que são sugeridos para este tipo de obra (2,0 a 4,0) (KOERNER, 2005), o efeito do confinamento em 
areia resultaria em uma redução do fator entre 44 e $72 \%$, em relação aos valores mínimo $(2,0)$ e máximo $(4,0)$ sugeridos, respectivamente. Além disso, Koerner (2005) recomenda que, para geotêxteis manufaturados de poliéster, o fator de redução devido à fluência deve estar entre 2,0 e 2,5. Deste modo, quando esses valores são comparados ao encontrado para o GTN $(1,13)$, levam a uma redução entre 44 e $55 \%$ do FR devido à fluência. No entanto, é importante salientar que o cálculo do fator de redução devido à fluência para esse geossintético é baseado em apenas um único conjunto de dados, sendo necessária a execução de outras séries de ensaios, a fim de proporcionar uma melhor caracterização desse comportamento para este material.

Portanto, a partir desses valores, considera-se que os fatores de redução devido à fluência sugeridos pela literatura técnica apresentam-se conservadores, levando também a valores conservadores da resistência à tração admissível dos geossintéticos empregados em projeto de estruturas de solo reforçado (determinado de acordo com a Equação 10). Por essa razão, sugere-se que o comportamento em fluência sob tração dos geossintéticos deva ser caracterizado no âmbito de confinamento em solo.

Por outro lado, nota-se na Figura 4.12 e nos valores da Tabela 4.11 uma diferença considerável entre os tempos encontrados na ruptura por fluência para cada nível de carregamento aplicado ao corpo de prova de GTN. Perante a esta variabilidade, avaliou-se a influência do confinamento no comportamento em deformação por fluência, para cada nível de carregamento utilizado nos ensaios conduzidos no GTN. Adicionalmente, levou-se em consideração as análises realizadas para o nível de carregamento de $50 \%$ da resistência à tração desse geossintético (valores discutidos no item 4.1.1).

Os valores dos índices de fluência obtidos em cada ensaio convencional (Conv) e confinada (C) foram comparados em função dos respectivos níveis de carregamentos. A Figura 4.13 apresenta o índice de fluência em função do nível de carregamento dos ensaios, para cada condição (não confinado e confinamento em areia). $\mathrm{O}$ ajuste dos pontos foi realizado através de regressão polinomial de segundo grau, que são indicadas nas Equações 18 e 19, para a condição de isolamento (não confinado) e de confinamento, respectivamente.

$$
\begin{aligned}
& T_{\alpha}=7,57 \cdot 10^{-5} \cdot\left(\frac{T}{T_{\text {últ }}}\right)^{2}+7,44 \cdot 10^{-3} \cdot\left(\frac{T}{T_{\text {últ }}}\right)+4,09 \cdot 10^{-1} \\
& T_{\alpha}=4,83 \cdot 10^{-4} \cdot\left(\frac{T}{T_{\text {últ }}}\right)^{2}-4,03 \cdot 10^{-2} \cdot\left(\frac{T}{T_{\text {úl } l}}\right)+9,26 \cdot 10^{-1}
\end{aligned}
$$


onde $\mathrm{T}_{\alpha}$ é o índice de fluência para cada condição de ensaio (isolamento ou confinado em areia); $\frac{T}{T_{\text {últ }}}$ é o nível de carregamento aplicado, referente a porcentagem da resistência à tração do material, em \%. O ajuste por regressão polinomial de segundo grau desses dados resultou em um $\mathrm{R}^{2}$ igual a 0,98 e 0,99 , respectivamente.

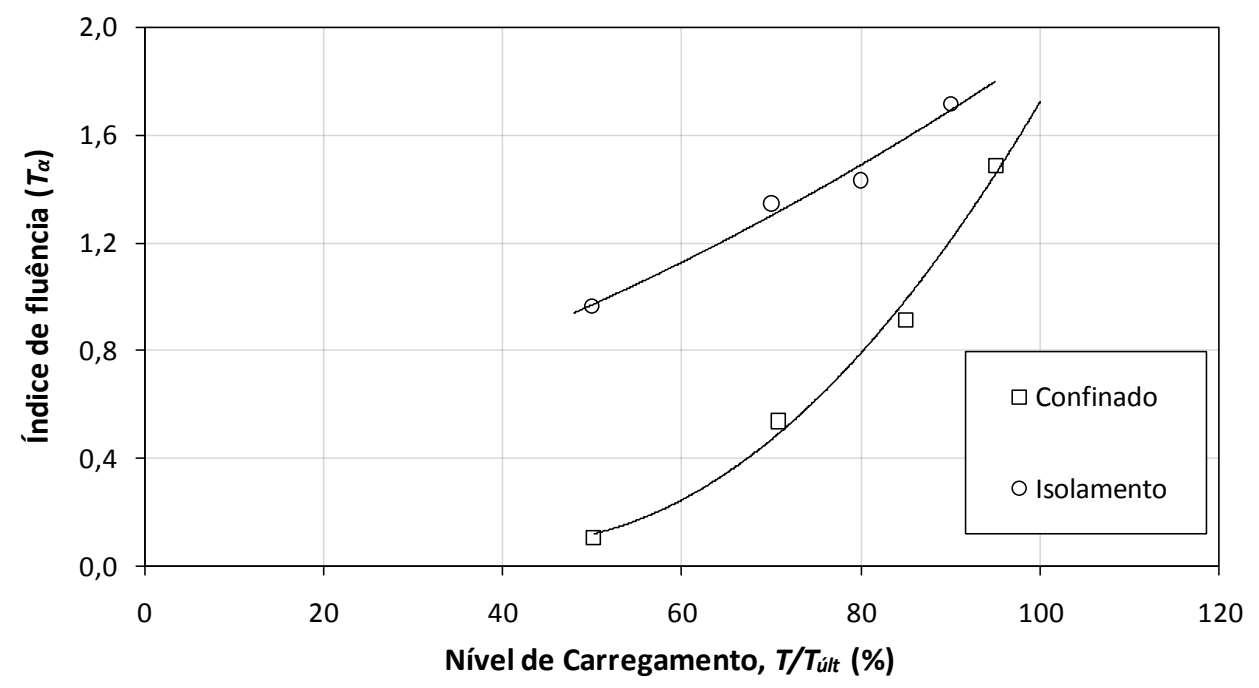

Figura 4.13 - Índice de fluência obtidos nos ensaios de fluência convencional e confinado em função do nível de carregamento aplicado (ensaios com GTN).

Além disso, a Tabela 4.12 apresenta os valores dos índices de fluência para cada nível de carregamento.

Tabela 4.12 - Índice de fluência para cada nível de carregamento e condição de ensaio.

\begin{tabular}{ccc}
\hline \multirow{2}{*}{ Tipo de ensaio } & $\begin{array}{c}\text { Nível de carregamento } \\
\text { nominal }(\%)^{1}\end{array}$ & $\begin{array}{c}\text { Índice de fluência, } \\
T_{\alpha}\end{array}$ \\
\hline \multirow{3}{*}{ Isolamento } & 90 & 1,714 \\
(não confinado) & 80 & 1,430 \\
& 70 & 1,345 \\
& 50 & 0,963 \\
\hline \multirow{2}{*}{ Confinado } & 95 & 1,485 \\
& 85 & 0,914 \\
& 70 & 0,539 \\
\hline 1 - Porcentagem da resistência à tração do material $\left(\mathrm{T} / \mathrm{T}_{\text {últ }}\right)$.
\end{tabular}


Nota-se na Figura 4.13 e na Tabela 4.12 a diferença entre os valores dos índices de fluência para diferentes condições de ensaio (isolamento e confinamento). Observa-se também, uma redução do efeito do confinamento com o aumento do nível de carregamento aplicado ao corpo de prova. Desta forma, esta série de ensaios mostra que a influência do confinamento nas deformações por fluência é maior para níveis de carregamento menores. A partir destes valores, a Figura 4.14 apresenta a redução do índice de fluência $\left(T_{\alpha}\right)$ em função do nível de carregamento aplicado. A curva obtida por regressão polinomial de segundo grau desses pontos está apresentada na Equação 20. Salienta-se que, nesta análise foram correlacionados os índices de fluência dos carregamentos 95 e 85\% (confinamento), com os encontrados nos níveis de 90 e $80 \%$ (isolamento) e a respectiva redução de $\mathrm{T}_{\alpha}$ é apresentada em função da média dos níveis de carregamento (92,5 e 82,5\%, respectivamente).

$$
R T_{\alpha}=-0,016 \cdot\left(\frac{T}{T_{\mathrm{u} l t}}\right)^{2}+0,461 \cdot\left(\frac{T}{T_{\mathrm{u} l t}}\right)+105,256
$$

onde $R T_{\alpha}$ é a redução do índice de fluência, em \%; $\frac{T}{T_{u} \text { út }}$ é o nível de carregamento aplicado, referente a porcentagem da resistência à tração do material, em \%.

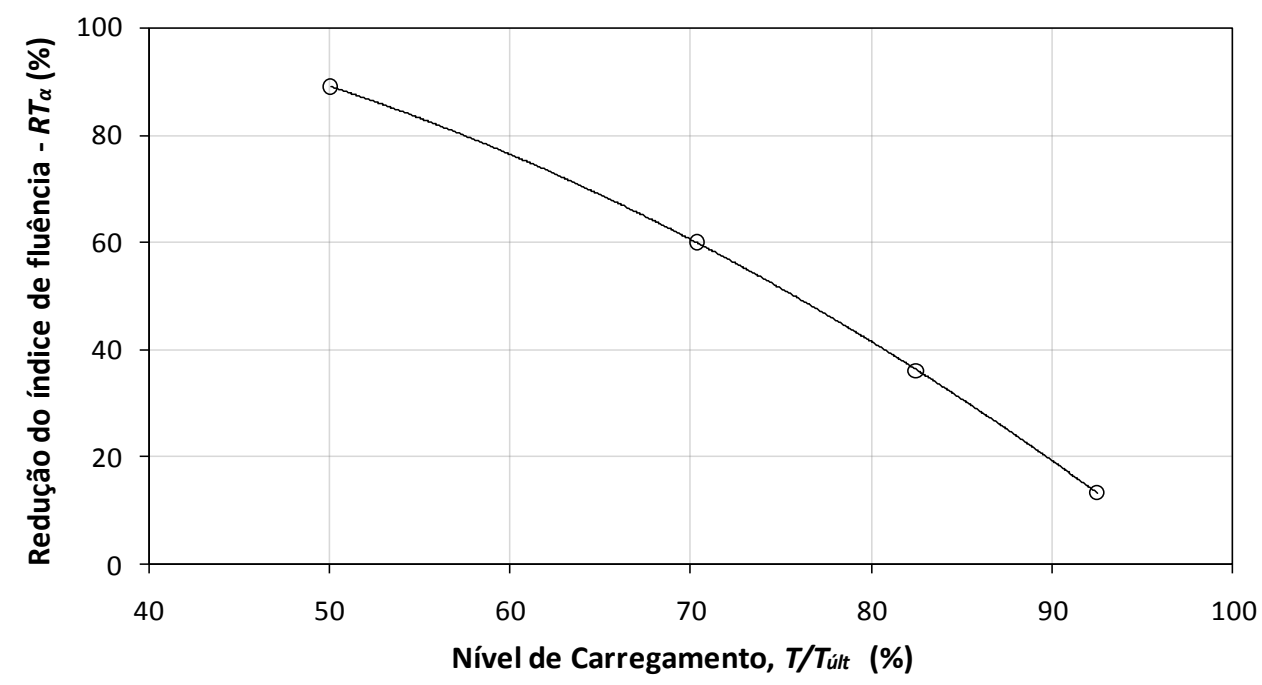

Figura 4.14 -Redução do índice de fluência $\left(\mathrm{T}_{\alpha}\right)$ por conta do confinamento em função do nível de carregamento aplicado aos ensaios conduzidos com o GTN.

Desta forma, a interpretação da Figura 4.14 juntamente com a Equação 20, leva ao valor da redução do índice de fluência devido ao confinamento em areia (com tensão normal de $50 \mathrm{kPa})$ para cada nível de carregamento aplicado os ensaios conduzidos no GTN. No 
entanto, vale salientar que esta relação é baseada em apenas uma série de ensaios.

\subsection{Geogrelha biaxial de poliéster (GG)}

Uma série de ensaios convencionais foi realizada na geogrelha biaxial de poliéster (GG) a fim de caracterizar o seu comportamento em deformação por fluência. Os níveis de carregamento empregados estão entre 20 e 50\% da resistência à tração desse material, todos no sentido longitudinal de fabricação. Estes ensaios foram executados em cavaletes metálicos padronizados, empregando-se pesos livres para a reprodução da solicitação de tração e que foram mantidos por no mínimo 1.000 horas. Os resultados dos ensaios convencionais de fluência conduzidos na geogrelha estão apresentados na Figura 4.15.

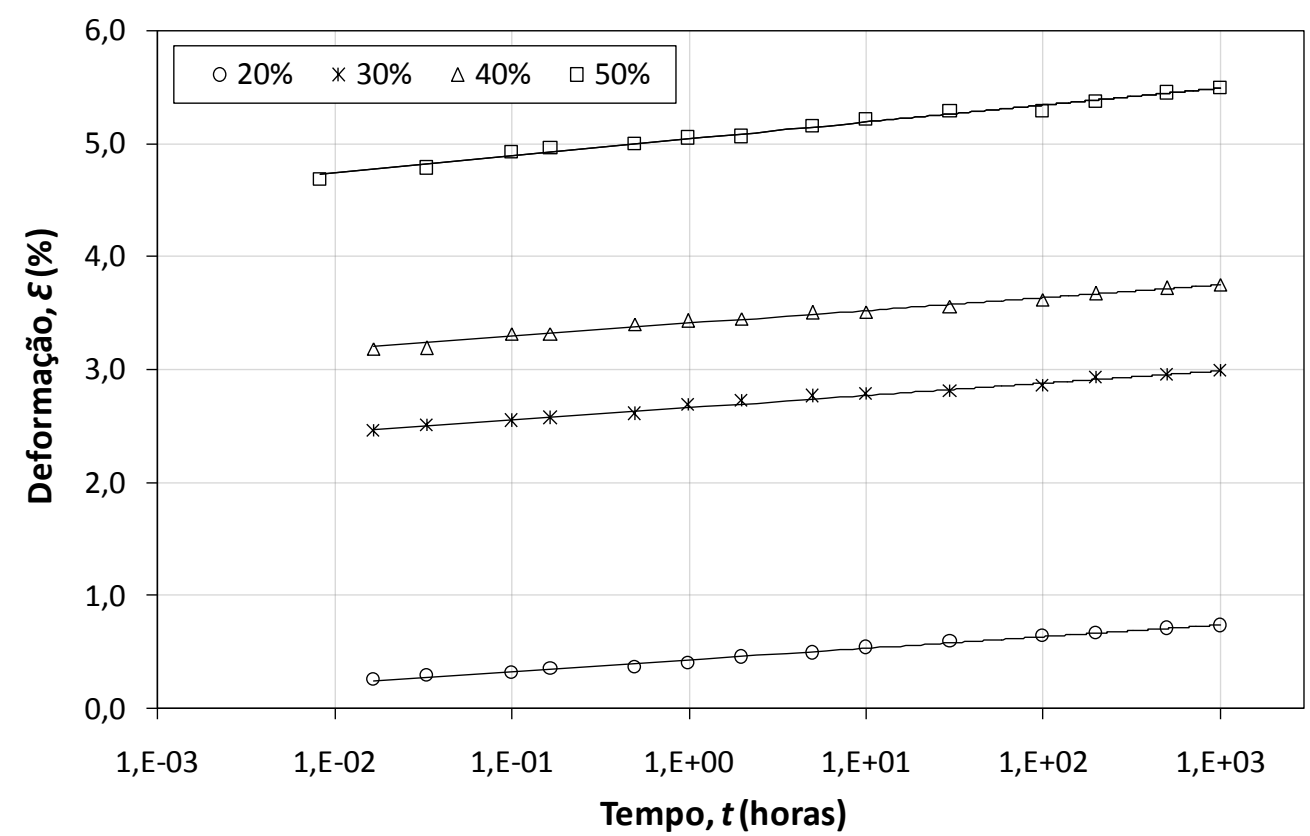

Figura 4.15 - Curvas de fluência obtidas nos ensaios convencionais de fluência conduzidos com a geogrelha biaxial de poliéster (GG).

$\mathrm{O}$ ajuste dos pontos experimentais de cada ensaios foi realizado por meio de regressão logarítmica, conforme apresentado na Equação 13. Além disso, a Tabela 4.13 apresenta os parâmetros obtidos com base nessa equação. 
Tabela 4.13 - Parâmetros obtidos através das regressões logarítmicas (Equação 13) dos dados experimentais dos ensaios convencionais conduzidos na GG.

\begin{tabular}{ccccc}
\hline $\begin{array}{c}\text { Nível de carregamento } \\
\text { nominal (\%) }\end{array}$ & $\begin{array}{c}\text { Deformação } \\
\text { inicial (\%) }\end{array}$ & $\mathrm{a}$ & $\mathrm{b}$ & $\mathrm{R}^{2}$ \\
\hline 50 & 4,68 & 0,162 & 5,04 & 0,97 \\
40 & 3,18 & 0,119 & 3,40 & 0,97 \\
30 & 2,45 & 0,114 & 2,66 & 0,98 \\
20 & 0,26 & 0,099 & 0,43 & 0,98 \\
\hline
\end{tabular}

1 - Porcentagem da resistência à tração do material $\left(\mathrm{T} / \mathrm{T}_{\text {út }}\right)$;

2 - Deformação inicial obtida a partir da análise de cada ensaio.

Conforme sugerido para o GTN, a representação gráfica dos ensaios de fluência também pode ser apresentada apenas em termos de deformação por fluência. Desta forma, a Figura 4.16 ilustra novamente os dados dos ensaios convencionais conduzidos na GG, segundo esta representação.

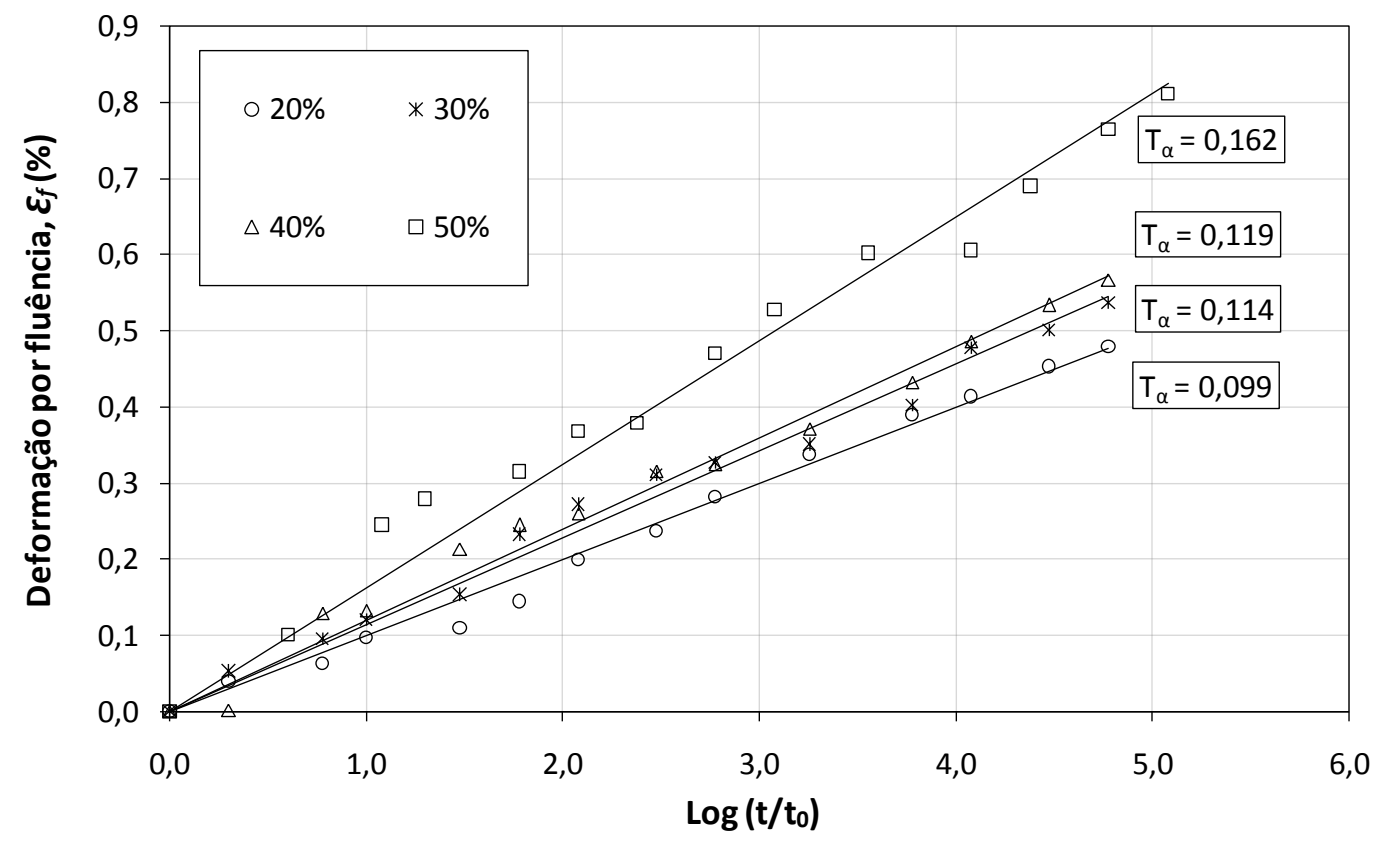

Figura 4.16 - Deformações por fluência dos ensaios convencionais de fluência conduzidos na GG, segundo a proposta de Zornberg et al. (2004).

Os valores do índice de fluência são obtidos com base na Equação 14 e estão apresentados na Tabela 4.14. 
Tabela 4.14 - Índice de fluência obtidos nos ensaios convencionais conduzidos na GG.

\begin{tabular}{cc}
\hline $\begin{array}{c}\text { Nível de carregamento } \\
\text { nominal }(\%)^{1}\end{array}$ & Índice de fluência, $T_{\alpha}$ \\
\hline 50 & 0,162 \\
40 & 0,119 \\
30 & 0,114 \\
20 & 0,099 \\
\hline
\end{tabular}

1 - Porcentagem da resistência à tração do material $\left(\mathrm{T} / \mathrm{T}_{\text {út }}\right)$.

Nota-se na Figura 4.16 e na Tabela 4.14 que os valores do índice de fluência $\left(\mathrm{T}_{\alpha}\right)$ foram crescentes de acordo com o aumento do nível de carregamento (porcentagem da resistência à tração do geossintético) aplicado ao ensaio convencional de fluência. A Figura 4.17 ilustra a variação do índice de fluência e das deformações iniciais dos corpos de prova em função do nível de carregamento para os ensaios convencionais de fluência conduzidos com a GG.

a)

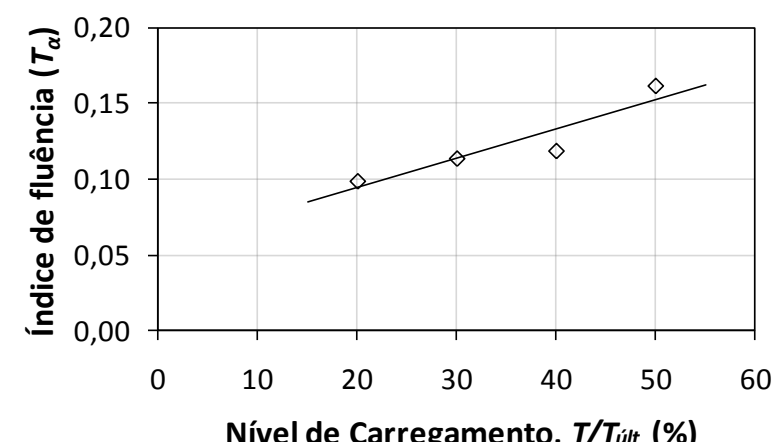

b)

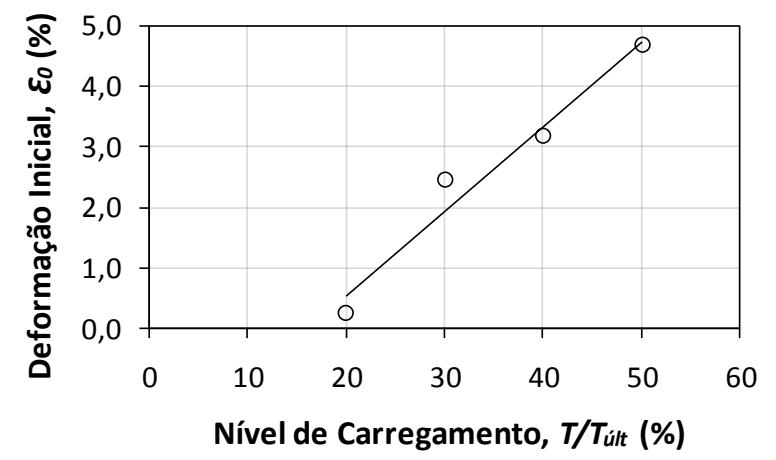

Figura 4.17 - (a) Índice de fluência e (b) deformação inicial dos corpos de prova em função do nível de carregamento aplicado aos ensaios convencionais de fluência conduzidos na GG.

$\mathrm{O}$ ajuste dos pontos experimentais do índice de fluência $\left(\mathrm{T}_{\alpha}\right)$ foi realizado através de regressão linear e é apresentada pela Equação 21.

$$
T_{\alpha}=0,002 \cdot\left(\frac{T}{T_{\text {últ }}}\right)+0,056
$$

onde $T_{\alpha}$ é o índice de fluência; $\left(\frac{T}{T_{\text {últ }}}\right)$ é o nível de carregamento aplicado, referente a porcentagem da resistência à tração do material. Essa relação levou a um $\mathrm{R}^{2}$ igual a 0,86 . 
Com relação à deformação inicial dos corpos de prova, obteve-se a relação indicada na Equação 22.

$$
\varepsilon_{0}=0,14 \cdot\left(\frac{T}{T_{\text {últ }}}\right)-2,254
$$

onde $\varepsilon_{0}$ é a deformação inicial do corpo de prova, em $\% ;\left(\frac{T}{T_{\text {últ }}}\right)$ é o nível de carregamento aplicado, referente a porcentagem da resistência à tração do material. O ajuste linear desses dados resultou em um $\mathrm{R}^{2}$ igual a 0,96 .

Conforme pôde ser observado na Figura 4.17, tanto a variação do índice de fluência, quanto às deformações iniciais dos corpos de prova em função do nível de carregamento apresentaram ajustes lineares satisfatórios, levando-se em conta que a variabilidade destes parâmetros pode ser atribuída ao procedimento de carregamento da solicitação de tração (realizado manualmente).

\subsubsection{Avaliação da influência do confinamento e da temperatura no comportamento em fluência da GG}

O item em questão apresenta e discute os resultados dos ensaios conduzidos na geogrelha biaxial de poliéster (GG), que tiveram por objetivo avaliar a influência do confinamento e da elevação da temperatura no comportamento em deformações por fluência deste geossintético. De forma similar ao apresentado para o GTN, esta análise foi realizada por meio de ensaios convencionais (Conv), confinado (C), confinado e acelerado (CA) e acelerado (A), todos conduzidos na direção longitudinal de fabricação do geossintético. $\mathrm{O}$ nível de carregamento empregado foi igual a 50\% da resistência à tração da GG. Este valor assemelha-se aquele utilizado nos ensaios conduzidos no GTN (item 4.1.1) e foi escolhido devido ao comportamento em deformação por fluência apresentado pela geogrelha (pequenos índices de fluência). Desta forma, utilizou-se o maior nível de carregamento empregado nos ensaios convencionais executados.

Tomando-se como referência o resultado do ensaio de fluência convencional, com nível de carregamento de 50\%, primeiramente, foi realizado um ensaio em condição de confinamento (C), submetido a uma tensão normal de $50 \mathrm{kPa}$ e conduzido em temperatura ambiente $\left(24 \pm 0,2^{\circ} \mathrm{C}\right)$. Na sequência, executou-se um ensaio na mesma condição de 
confinamento (tensão normal de $50 \mathrm{kPa}$ ), porém com um acréscimo de temperatura de aproximadamente $12^{\circ} \mathrm{C}$ com relação à temperatura ambiente (ensaio confinado). Por fim, realizou-se um ensaio acelerado (A), em condição de isolamento (não confinado) e com temperatura de aproximadamente $36^{\circ} \mathrm{C}$. Empregou-se o mesmo salto de temperatura para os ensaios CA e A. A Figura 4.18 apresenta os pontos experimentais obtidos para nos ensaios de fluência conduzidos na GG.

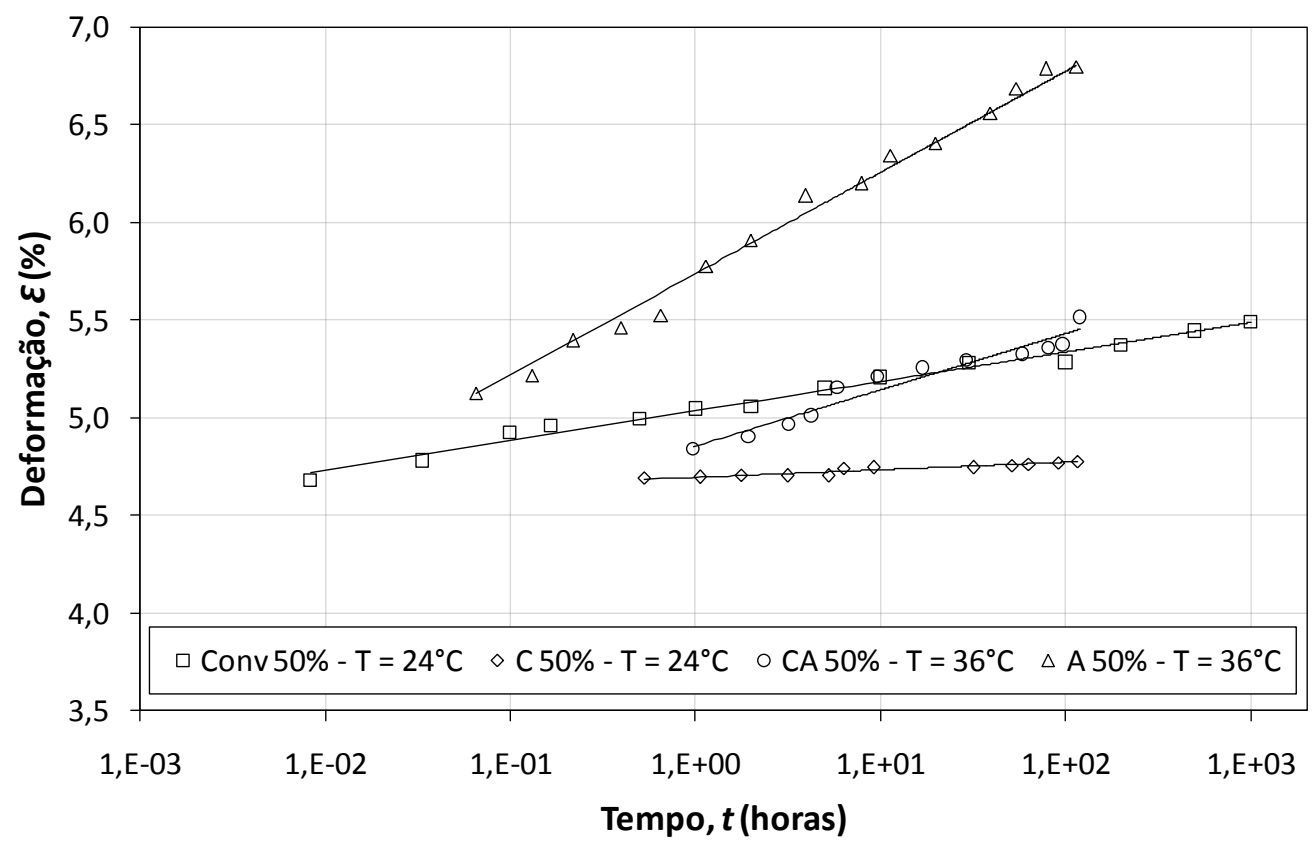

Figura 4.18 - Curvas de fluência obtidas a partir dos ensaios de fluência conduzidos na GG, para o nível de carregamento de $50 \%$ da resistência à tração desse geossintético.

A Tabela 4.15 sumariza os parâmetros obtidos pela regressão logarítmica (Equação 13) de cada conjunto de dados.

Tabela 4.15 - Parâmetros obtidos a partir das regressões logarítmicas (Equação 13) dos ensaios de fluência conduzidos na GG.

\begin{tabular}{cccccc}
\hline Tipo de ensaio & $\begin{array}{c}\text { Temperatura } \\
\text { do ensaio }\left({ }^{\circ} \mathrm{C}\right)\end{array}$ & $\begin{array}{c}\text { Deformação inicial } \\
(\%)^{2}\end{array}$ & $\mathrm{a}$ & $\mathrm{b}$ & $\mathrm{R}^{2}$ \\
\hline Conv 50\% & 24 & 4,68 & 0,162 & 5,04 & 0,99 \\
A 50\% & 36 & 5,14 & 0,512 & 5,74 & 0,95 \\
CA 50\% & 36 & 4,84 & 0,298 & 4,86 & 0,95 \\
C 50\% & 24 & 4,69 & 0,033 & 4,70 & 0,89 \\
\hline
\end{tabular}

1 - Porcentagem da resistência à tração do material $\left(\mathrm{T} / \mathrm{T}_{\text {út }}\right)$;

2 - Deformação inicial obtida a partir da análise de cada ensaio. 
A diferença entre as inclinações das retas de ajuste dos dados ilustrados na Figura 4.18 indica o efeito do confinamento e da elevação da temperatura do ensaio. No entanto, a Figura 4.19 ilustra os resultados desta série de ensaios apenas em termos de deformações por fluência.

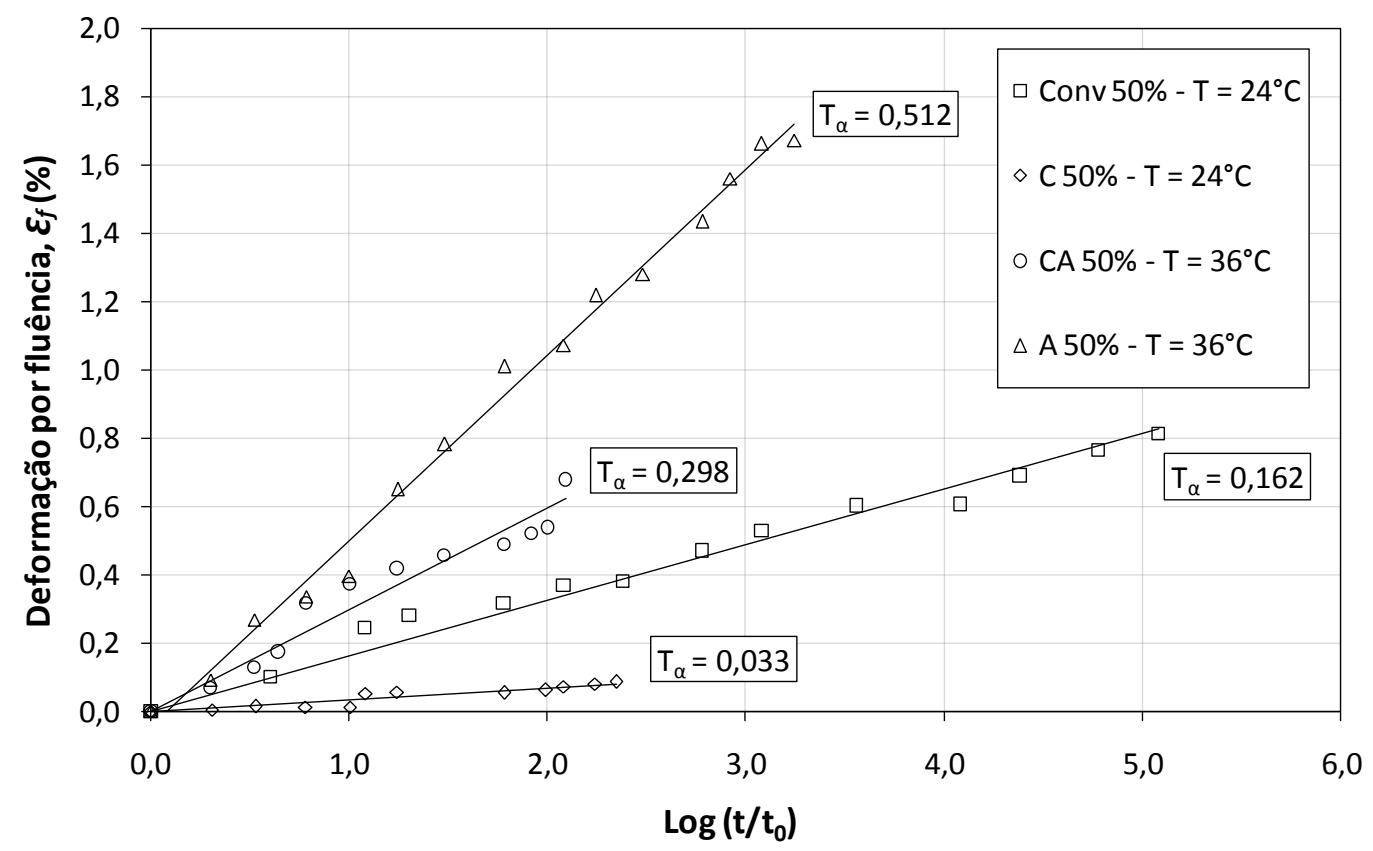

Figura 4.19 - Deformações por fluência obtidas a partir dos ensaios de fluência conduzidos na GG, para o carregamento de $50 \%$ da resistência à tração desse material.

$\mathrm{O}$ ajuste dos pontos experimentais de cada ensaio resultou em uma relação conforme indicado na Equação 14 e os parâmetros estão descritos na Tabela 4.16.

Tabela 4.16 - Parâmetros obtidos pela regressão linear (Equação 14) dos dados dos ensaios de fluência conduzidos no GG.

Tipo de ensaio ${ }^{1} \quad \begin{gathered}\text { Temperatura do ensaio } \\ \left({ }^{\circ} \mathrm{C}\right)\end{gathered} \quad$ Índice de fluência, $T_{\alpha}$

\begin{tabular}{ccc}
\hline Conv 50\% & 24 & 0,162 \\
A 50\% & 36 & 0,512 \\
CA 50\% & 36 & 0,298 \\
C 50\% & 24 & 0,033 \\
\hline
\end{tabular}

1 - Porcentagem da resistência à tração do material $\left(\mathrm{T} / \mathrm{T}_{\text {últ }}\right)$. 
A comparação entre os valores do índice de fluência $\left(\mathrm{T}_{\alpha}\right)$ ilustrados na Figura 4.19 e na Tabela 4.16 indicam a influência do confinamento (com tensão normal de $50 \mathrm{kPa}$ ) no comportamento em deformação por fluência da geogrelha biaxial de poliéster. Desta forma, verificou-se que o confinamento em areia para o ensaio conduzido em temperatura ambiente, resultou em um índice de fluência igual a 0,033. Este valor, quando comparado ao ensaio de fluência convencional $(0,162)$, levou a uma redução de aproximadamente $80 \%$ na taxa de deformação por fluência. Valores menos expressivos foram obtidos quando comparados os ensaios conduzidos em temperatura elevada (CA e A), com redução de aproximadamente $42 \%$ e índices de fluência de 0,298 e 0,512 para os ensaios CA e A, respectivamente. Isto se deve ao efeito da temperatura no comportamento em fluência desse geossintético. Esta influência também pôde ser observada nos ensaios conduzidos em isolamento, com índice de fluência de 0,162 e 0,512, para os ensaios de fluência convencional e acelerado, respectivamente.

Portanto, a partir desses resultados, observou-se que tanto o confinamento em areia, quanto a elevação da temperatura de ensaio influenciaram no comportamento em deformação por fluência deste geossintético. O efeito da elevação da temperatura vai ao encontro dos resultados reportados na literatura (FARRAG; SHIRAZI, 1997; ZORNBERG et al., 2004; FRANÇA; BUENO, 2011). No entanto, o efeito do confinamento na geogrelha estudada indica o contrário do que é abordado em grande parte da literatura técnica, na qual o efeito do confinamento é mais significativo em geossintéticos com distribuição aleatória das fibras (geotêxteis não-tecidos), menos significativos nos geotêxteis tecidos e praticamente ausente nas geogrelhas (KOERNER, 2005). Contudo, estes resultados vão ao encontro do apresentado por França (2012), em que uma geogrelha de poliéster quando confinada em areia (tensão normal de $50 \mathrm{kPa}$ ) resultou em uma redução de aproximadamente $94 \%$ nas taxas de deformação por fluência. Essa redução possivelmente se deve a interação entre o meio confinante e os elementos transversais da geogrelha, resultando na restrição do movimento dos elementos longitudinais.

Adicionalmente, compararam-se os resultados determinados nesta pesquisa aos obtidos por França (2012), que avaliou o comportamento em deformação por fluência de uma geogrelha biaxial de poliéster (resistência igual a $37,25 \mathrm{kN} / \mathrm{m}$ e deformação na ruptura de $10,87 \%$ no sentido longitudinal de fabricação; abertura nominal de 28,2 mm) submetida a mesma de solicitação de tração (50\% da resistência à tração do geossintético) e confinamento 
em areia (tensão normal de $50 \mathrm{kPa}$ ). A Tabela 4.17 apresenta o efeito do confinamento para as geogrelhas biaxiais de poliéster avaliadas nesta pesquisa e por França (2012). Destaca-se que os valores apresentados nesta tabela representam, em porcentagem, a redução da taxa de deformação por fluência devido ao confinamento em areia.

Tabela 4.17 - Análises conduzidas nesta pesquisa e realizadas por França (2012).

\begin{tabular}{ccc}
\hline \multirow{2}{*}{$\begin{array}{c}\text { Tipo de } \\
\text { Geossintéticos }\end{array}$} & Efeito do confinamento em areia com tensão normal de $50 \mathrm{kPa}$ \\
\cline { 2 - 3 } & C e Conv & CA e A \\
\hline GG $^{1}$ & $80 \%$ & $42 \%$ \\
França $(2012)^{2}$ & $94 \%$ & $52 \%{ }^{3}$ \\
\hline
\end{tabular}

1 - Resultados discutidos no item 4.2.1;

2 - Análises realizadas com os dados de França (2012);

3 - Ensaios conduzidos com temperatura de aproximadamente $43^{\circ} \mathrm{C}$.

Conforme apresentado na Tabela 4.17, observa-se que o efeito do confinamento resultou em valores relativamente próximos, tanto para os ensaios conduzidos em temperatura ambiente (C e Conv), quanto em temperatura elevada (A e Conv). A diferença obtida entre os ensaios conduzidos em temperatura elevada (CA e A) possivelmente se deve à diferença de temperatura empregada nos ensaios executados nesta pesquisa e por França (20120). Desta forma, sugere-se que o comportamento em confinamento para a fluência desse tipo de geossintético deva ser estudado.

Outro fator que pode ser destacado é o efeito das condições de ensaio nas deformações iniciais dos corpos de prova. A Tabela 4.18 apresenta as deformações iniciais e finais obtidas para cada corpo de prova, juntamente com as temperaturas e o tempo total de cada ensaio conduzido na GG.

Tabela 4.18 - Informações dos ensaios de fluência conduzidos na geogrelha biaxial de poliéster.

\begin{tabular}{cccccc}
\hline $\begin{array}{c}\text { Tipo de } \\
\text { ensaio }\end{array}$ & $\begin{array}{c}\text { Nomenclatura } \\
\text { do ensaio }\end{array}$ & $\begin{array}{c}\text { Temperatura } \\
\text { do ensaio }\left({ }^{\circ} \mathrm{C}\right)\end{array}$ & $\begin{array}{c}\text { Tempo total } \\
\text { de ensaio (h) }\end{array}$ & $\begin{array}{c}\text { Deformação } \\
\text { Inicial (\%) }\end{array}$ & $\begin{array}{c}\text { Deformação } \\
\text { final (\%) }\end{array}$ \\
\hline Conv & Conv 50\% & 24 & 1000,00 & 4,68 & 5,49 \\
A & A 50\% & 36 & 114,45 & 5,14 & 6,69 \\
C & C 50\% & 24 & 116,04 & 4,69 & 4,78 \\
CA & CA 50\% & 36 & 119,75 & 4,84 & 5,52 \\
\hline
\end{tabular}


Devido à diferença entre o procedimento de carregamento da solicitação de tração do corpo de prova, a comparação entre as deformações iniciais foi realizada apenas entre os ensaios conduzidos no equipamento de fluência confinada e acelerada (C, CA e A). Assim, observou-se uma redução de 5,8\% na deformação inicial devido ao confinamento em areia (deformações iniciais de 4,84 e 5,14\% para os ensaios CA e A, respectivamente). O efeito da temperatura é ilustrado entre as deformações iniciais dos ensaios confinado e acelerado $(4,84 \%)$ e confinado $(4,69 \%)$, resultando em um acréscimo de $3,2 \%$.

Conforme apresentado anteriormente, a realização de ensaios em temperaturas diferentes possibilitou a construção das curvas mestras de fluência para as condições de isolamento e confinamento em areia. A Figura 4.20 ilustra as curvas mestras obtidas com os dados experimentais de cada ensaio. Também são apresentadas as retas de regressão logarítmica dos dados, cuja equação segue a forma apresentada na Equação 13.

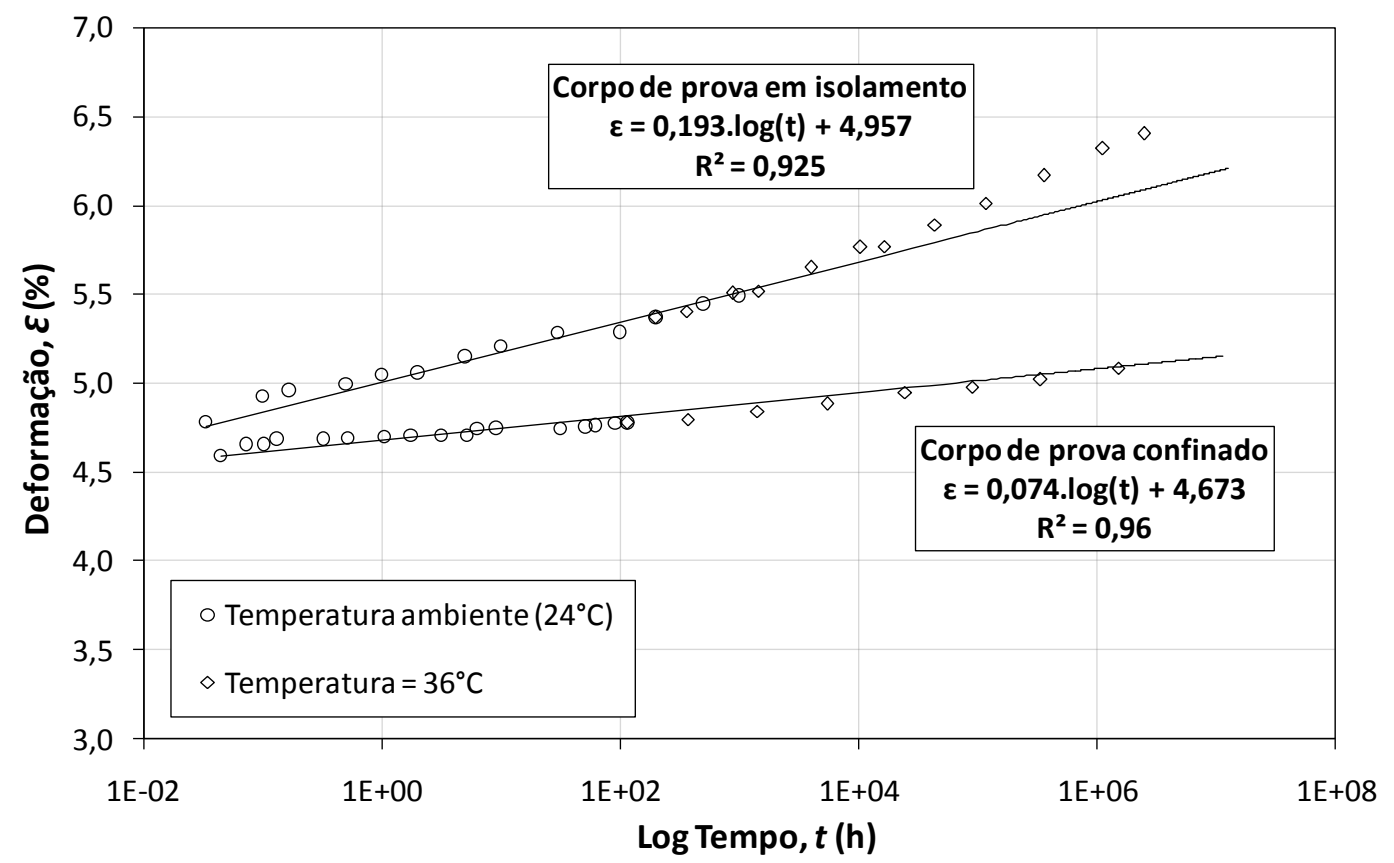

Figura 4.20 - Curvas mestras de fluência obtidas para a GG em condição de isolamento e em confinamento em areia, para o nível de carregamento igual a 50\% da resistência à tração desse material.

A comparação entre as inclinações das retas de ajustes das curvas mestras de fluência indicam a influência do confinamento nas deformações por fluência desta geogrelha. Desta forma, esta condição levou a uma redução de aproximadamente $62 \%$ nas taxas de 
deformação por fluência. Este valor foi menor que o apresentado na avaliação de cada ensaio isoladamente (aproximadamente 80\%). Entretanto, conforme citado no item 4.1.1, este valor representa a influência do confinamento em longo prazo, levando-se em conta que as curvas mestras apresentam o comportamento em fluência da GG por até 285 anos de ensaio. A Tabela 4.19 ilustra as características de cada curva mestra de fluência para a geogrelha biaxial de poliéster.

Tabela 4.19 - Características das curvas mestras de fluência para as condições em isolamento e confinamento (ensaios GG).

\begin{tabular}{ccccc}
\hline $\begin{array}{c}\text { Condição do } \\
\text { ensaio }^{1}\end{array}$ & $\begin{array}{c}\text { Nomenclatura do } \\
\text { ensaio }\end{array}$ & $\begin{array}{c}\text { Duração total de } \\
\text { ensaio (h) }\end{array}$ & $\begin{array}{c}\text { Deformação inicial } \\
\text { do ensaio (\%) }\end{array}$ & $\begin{array}{c}\text { Deformação final } \\
\text { do ensaio (\%) }\end{array}$ \\
\hline Isolamento & Curva Mestra 50\% & $2,50 \mathrm{E}+06$ & 4,78 & 6,40 \\
Confinado & Curva Mestra 50\% & $1,52 \mathrm{E}+06$ & 4,59 & 5,08 \\
\hline
\end{tabular}

1 - Condição da curva mestra de fluência;

2 - Duração total do ensaio interpretada na temperatura de referência (ambiente).

Nota-se na Tabela 4.19 que o confinamento em areia (tensão normal de $50 \mathrm{kPa}$ ) foi responsável por uma redução nas deformações iniciais de aproximadamente 4\% (4,78 e 4,59\% para a condição de isolamento e de confinamento, respectivamente). 


\section{Conclusões}

Esta dissertação apresentou uma investigação da fluência em geossintéticos com base em diferentes configurações de ensaio. O programa experimental permitiu avaliar o comportamento da fluência em condições de confinamento em areia e devido à elevação da temperatura de ensaio, quando tratadas de forma isolada ou em conjunto. Foram utilizados dois tipos de geossintético, um geotêxtil não-tecido de fibra curta (GTN) e uma geogrelha biaxial (GG), ambos manufaturados de poliéster (PET). Além disso, foram realizados ensaios convencionais de fluência para os dois materiais, permitindo a comparação entre os diferentes ensaios de fluência realizados.

Com base nos resultados obtidos e discutidos anteriormente, o presente trabalho permite concluir que:

- O confinamento em areia com tensão normal de $50 \mathrm{kPa}$ apresentou-se bastante eficaz para o geotêxtil não-tecido de poliéster $(\mathrm{GTN})$, visto que resultou numa redução de aproximadamente $89 \%$ na taxa de deformação por fluência para os ensaios conduzidos em temperatura ambiente. Outro fator que pode ser destacado é o efeito do confinamento para os ensaios conduzidos em temperatura elevada $\left(36^{\circ} \mathrm{C}\right)$, resultando em uma redução de aproximadamente $69 \%$ devido ao confinamento. Estes valores apresentaram-se coerentes com os apresentados na literatura e quando comparados aos obtidos por França (2012). Por fim, a avaliação das curvas mestras de fluência do GTN em condição de isolamento e confinamento possibilitou quantificar o efeito do confinamento no comportamento em deformação por fluência deste material em longo prazo. Observou-se uma redução de aproximadamente $77 \%$ na taxa de deformações por fluência, valor menor que o apresentado na avaliação de cada ensaio isoladamente (aproximadamente $89 \%$ );

- A construção da curva de ruptura por fluência do geotêxtil não-tecido de poliéster (GTN) em condição de confinamento possibilitou a determinação do fator de redução devido à fluência para esse material. Desta forma, considerando-se uma vida útil de projeto entre 75 e 100 anos, obteve-se um fator de redução devido à fluência igual a 1,13. Este valor, quando comparado aos relatados na literatura técnica, levou a uma redução entre 44 e $72 \%$ para esse tipo de obra. Além disso, conduziu a uma redução entre 44 e 55\%, considerando os valores abordados para geotêxteis de poliéster. Portanto, em vista dos valores 
apresentados, considera-se que o fator de redução devido à fluência sugeridos na literatura técnica são conservadores e por essa razão, recomenda-se que o confinamento em solo deva ser levado em consideração na determinação do comportamento em fluência sob tração dos geossintéticos;

- Observou-se que o efeito do confinamento no comportamento em deformação por fluência do geotêxtil não-tecido de poliéster (GTN) é dependente do nível de carregamento aplicado ao corpo de prova. Assim sendo, nota-se uma redução do efeito do confinamento com o aumento do nível de carregamento aplicado ao corpo de prova, ou seja, a influência do confinamento nas deformações por fluência é maior em níveis de carregamento menores;

- O comportamento em deformação por fluência da geogrelha biaxial de poliéster (GG) mostrou-se dependente do confinamento em areia (com tensão normal de 50 $\mathrm{kPa}$ ). Verificou-se uma redução de aproximadamente $80 \%$ na taxa de deformação por fluência, quando avaliados os ensaios executados em temperatura ambiente. Valores menos expressivos foram encontrados quando para os ensaios conduzidos em temperatura elevada $\left(36^{\circ} \mathrm{C}\right)$, com redução de aproximadamente $42 \%$. Além disso, a interpretação das curvas mestras de fluência obtidas para as condições de isolamento e confinamento possibilitou quantificar o efeito do confinamento nas deformações por fluência em longo prazo, que resultou em uma redução de aproximadamente $62 \%$ nas taxas de deformação por fluência. Este valor foi menor que o encontrado na avaliação de cada ensaio isoladamente (aproximadamente 80\%). Assim, esses resultados indicam o contrário do que é apresentado por grande parte da literatura técnica. Contudo, vão ao encontro dos resultados apresentados por França (2012). Desta forma, sugere-se que o efeito do confinamento no comportamento em deformação por fluência deva ser analisado para este tipo de geossintético;

- O desempenho do equipamento de fluência confinada e acelerada foi melhorado através da adição de um sistema de carregamento da solicitação de tração. Este acessório mostrou-se capaz de aplicar o carregamento de solicitação de tração de maneira uniforme em ambas as extremidades dos corpos de prova, bem como manter constante a velocidade de aplicação desse carregamento;

- Verificou-se que a variabilidade da resistência à tração do geotêxtil não-tecido pode ser analisada em função da gramatura do material. Desta forma, foi possível determinar a resistência de cada corpo de prova utilizado no programa experimental desta pesquisa. $\mathrm{O}$ 
valor deste parâmetro foi empregado para a correção do nível de carregamento de cada ensaio de fluência conduzido com esse material;

- Ambos os geossintéticos empregados no programa experimental desta pesquisa apresentaram comportamento em deformação por fluência dependentes da temperatura de ensaio. Este fenômeno foi observado através do aumento do índice de fluência $\left(T_{\alpha}\right)$ do material, tanto para os ensaios conduzidos em isolamento (não confinado), quanto para os ensaios realizados em confinamento;

- As deformações iniciais dos corpos de prova de ambos os geossintéticos mostraram-se dependentes da configuração de ensaio empregada, apresentando redução quando em meio confinado e aumento, na condição de temperatura elevada. 
- 124 - 


\section{Proposta para Estudos Futuros}

A continuidade dos estudos nesta linha de pesquisa se faz necessária para esclarecer outros fatores importantes no conhecimento do comportamento em fluência dos geossintéticos. Desta forma, ensaios adicionais e outros estudos subsequentes são propostos nesta dissertação:

- A partir da implementação realizada ao equipamento de fluência confinada e acelerada, sugere-se a realização de ensaios de tração confinada e, com base nesses resultados, realizar ensaios de fluência confinada aplicando-se os valores de resistência obtidos nesses ensaios;

- Ensaios confinados de fluência em diferentes níveis de tensão normal, verificando a influência desse fator nas deformações por fluência do geossintético;

- Ensaios confinados de fluência empregando-se outros meios confinantes;

- Execução de ensaios de ruptura por fluência em meio confinado para outros geossintéticos, a fim de comprovar a influência desse efeito na redução do fator de redução devido à fluência;

- Realização de ensaios convencionais de fluência no equipamento de fluência confinada e acelerada, para verificar a correspondência com aqueles obtidos em equipamentos padronizados. 
- 126 -

$6-$ 


\section{Referências}

ABRAMENTO, M. (1995). Durabilidade e comportamento de longo prazo de geossintéticos Parte I: Propriedades mecânicas e hidráulicas. In: Geossintéticos 95. Anais. São Paulo, p. $217-$ 226.

AGAR; J. G.; MORGENSTERN, N. R.; SCOTT, J. D. (1987). Shear strength and stressstrain behaviour of Athabasca oil sand at elevated temperatures and pressures. Canadian Geotechnical Journal, v. 24, n. 1, p. 1-10.

AGUIAR, P. R.; VERTEMATTI, J. C. (2004). Introdução. In: VERTEMATTI, J. C. Manual brasileiro de geossintéticos. São Paulo: Edgard Blücher. Cap. 1, p. 1-12.

ALLEN, T. M. (1991). Determination of long-term strength of geosynthetics: A state-of-theart review. In: GEOSYNTHETICS'91, 1991, Atlanta, Proceedings. Atlanta: International Geosynthetic Society, 1991. p. 351-379.

AMERICAN SOCIETY FOR TESTING AND MATERIALS (2003). ASTM D 6992: Standard test method for accelerated tensile creep and creep rupture of geosynthetic materials based on time-temperature superposition using the stepped isothermal method.

AMERICAN SOCIETY FOR TESTING AND MATERIALS (2005). ASTM D 4595: standard test method for tensile properties of geotextiles by the wide-width strip method. West Conshohocken.

AMERICAN SOCIETY FOR TESTING AND MATERIALS (2007). ASTM D 5262: Standard test method for evaluating the unconfined tension creep behavior of geosynthetics.

AMERICAN SOCIETY FOR TESTING AND MATERIALS (2001). ASTM D 6637: standard test method for determining tensile properties of geogrids by the single or multi-rib tensile method. West Conshohocken.

ANDRAWES, K. Z.; McGOWN, A.; KABIR, M. H. (1984). Uniaxial strength testing of woven and nonwoven geotextiles. Geotextiles and Geomembranes, v. 1, n. 1, p. 41-56.

ASSOCIAÇÃO BRASILEIRA DE NORMAS TÉCNICAS (1984). NBR 6.508: grãos de solo que passam na peneira de 4,8 mm - determinação da massa específica. Rio de Janeiro.

ASSOCIAÇÃO BRASILEIRA DE NORMAS TÉCNICAS (1984). NBR 7.181: solo - análise 
granulométrica. Rio de Janeiro.

ASSOCIAÇÃO BRASILEIRA DE NORMAS TÉCNICAS (1990). NBR 12.004: solo determinação do índice de vazios máximo de solos não coesivos. Rio de Janeiro.

ASSOCIAÇÃO BRASILEIRA DE NORMAS TÉCNICAS (1991). NBR 12.051: solo determinação do índice de vazios mínimo de solos não coesivos. Rio de Janeiro.

ASSOCIAÇÃO BRASILEIRA DE NORMAS TÉCNICAS (2003). NBR 12.568: Geotêxteis - Determinação da massa por unidade de área. Rio de Janeiro.

ASSOCIAÇÃO BRASILEIRA DE NORMAS TÉCNICAS (1992). NBR 12.569: Geotêxteis Determinação da espessura. Rio de Janeiro.

ASSOCIAÇÃO BRASILEIRA DE NORMAS TÉCNICAS (1993). NBR 12.824: geotêxteis: determinação da resistência à tração não confinada - ensaio de tração de faixa larga. Rio de Janeiro.

ASSOCIAÇÃO BRASILEIRA DE NORMAS TÉCNICAS (2003). NBR 12.553: Geossintéticos - Terminologia. Rio de Janeiro.

ASSOCIAÇÃO BRASILEIRA DE NORMAS TÉCNICAS (2005). NBR 15.226: Geossintéticos - Determinação do comportamento em deformação e na ruptura, por fluência sob tração não confinada. Rio de Janeiro.

BARAS, L. C. S. (2001). Estudo da fluência em geotêxteis através de ensaios não confinados convencionais e acelerados. Dissertação (Mestrado em Geotecnia) - Departamento de Geotecnia, Escola de Engenharia de São Carlos, Universidade de São Paulo, São Carlos, 134 p.

BARAS, L. C. S.; BUENO, B. S.; COSTA, C. M. L. (2002). On the evaluation of stepped isothermal method for characterizing creep properties of geotextiles. In: Geosynthetics - 7th ICG. Swets \& Zeitlinger, Lisse ISBN 905809523 1. p.1515-1518.

BECKER, L. D. B.; NUNES, A. L. L. S. (2002). Confined creep of geotextile in a compacted sand fill. In: Geosynthetics - 7th ICG. Swets \& Zeitlinger, Lisse ISBN 905809523 1. p.15191522.

BUENO, B. S. (2004). Matérias-primas. In: VERTEMATTI, J. C. Manual brasileiro de 
geossintéticos. São Paulo: Edgard Blücher. Cap. 2, p. 13-26.

BUENO, B. S.; COSTANZI, M. A.; ZORNBERG, J. G. (2005). Conventional and accelerated creep tests on nonwoven needle-punched geotextiles. Geosynthetics International, v. 12, n. 6, p. 276-287.

BUENO, B. S.; VILAR, O. M. (2004). Propriedades, Ensaios e Normas. In: VERTEMATTI, J. C. Manual brasileiro de geossintéticos. São Paulo: Edgard Blücher. Cap. 3, p. 27-62.

CAZZUFFI, D.; GHINELli, A.; SACCHETTI, M.; VILLA, C. (1997). European experimental approach to the tensile creep behavior of high-strength geosynthetics. In: Geosynthetics' 97. Proceedings. California. v.1., p. 253-266.

CHRISTOPHER, B. R.; HOLTZ, R. D; ALLEN, T. M. (1990). Instrumentation for a 12.6 m high geotextile-reinforced wall. In: International Reinforced Soil Conference - Performance of Reinforced Soil Structures. Proceedings. British Geotechnical Society, p. 73-78.

COSTA, C. M. L. (1999). Fluência de geotêxteis. Dissertação (Mestrado em Geotecnia) Departamento de Geotecnia, Escola de Engenharia de São Carlos, Universidade de São Paulo, São Carlos, 116 p.

COSTA, C. M. L. (2004). Deformações dependentes do tempo em muros de solo reforçado com geotêxteis. Tese (Doutorado em Geotecnia) - Departamento de Geotecnia, Escola de Engenharia de São Carlos, Universidade de São Paulo, São Carlos, 362 p.

COSTANZI, M. A. (2003). Emprego do método SIM para obtenção das curvas isócronas e de ruptura por fluência. Dissertação (Mestrado em Geotecnia) - Departamento de Geotecnia, Escola de Engenharia de São Carlos, Universidade de São Paulo, São Carlos, 95 p.

COSTANZI, M. A.; BUENO, B. S.; BARAS, L. C. S.; ZORNBERG, J. G. (2003). Avaliação da fluência de geotêxteis não tecidos com ensaios acelerados. Solos e Rochas, v. 26, n. 3, p. 12.

DEAN, G. D.; BROUGHTON, W. (2007). A model for non-linear creep in polypropylene. Polymer Testing, v. 26, n. 8, p. 1068-1081.

DEN HOEDT, G. (1986). Creep and relaxation of geotextiles fabrics. Geotextiles and Geomembranes, v. 4, n. 2, p. 83-92. 
ELIAS, V.; CHRISTOPHER, B. R.; BERG, R. R. (2001). Mechanically stabilized earth walls and reinforced soil slopes design \& construction guidelines. US. Department of Transportation, Publication No. FHWA-NHI-00-043, 394 p.

FARRAG, K. (1998). Development of an accelerated creep testing procedure for geosynthetics - Part 2: Analysis. Geotechnical Testing Journal, v. 21, n. 1, p. 38-44.

FARRAG, K.; SHIRAZI, H. (1997). Development of an accelerated creep testing procedure for geosynthetics - Part 1: Testing. Geotechnical Testing Journal, v. 20, n. 4, p. 414-422.

FERRY, J. D. (1980). Viscoelastic properties of polymers. 3. ed. New York: John Wiley \& Sons, $641 \mathrm{p}$.

FRANÇA, F. A. N. (2012). Novo equipamento para realização de ensaios confinados e acelerados de fluência em geossintéticos. Tese (Doutorado em Geotecnia) - Departamento de Geotecnia, Escola de Engenharia de São Carlos, Universidade de São Paulo, São Carlos, 263 p.

FRANÇA, F. A. N.; BUENO, B. S. (2011). Creep behavior of geosynthetics using confinedaccelerated tests. Geosynthetics International, 18, No. 5, p. 242-254. [http://dx.doi.org/10.1680/ gein.2011.18.5.242].

FRANÇA, F. A. N.; BUENO, B. S.; ZORNBERG, J. G. (2011). Novo equipamento para realização de ensaios de fluência simultaneamente confinados e acelerados. VII Congresso Brasileiro de Geotecnia Ambiental e VI Simpósio Brasileiro de Geossintético REGEO/Geossintéticos 2011. Belo Horizonte, MG, 8 p.

GRAHAM, J.; ALFARO, M.; FERRIS, G. (2004). Compression and strength of dense sand at high pressures and elevated temperature. Canadian Geotechnical Journal, v. 41, n. 6, p. 12061212.

INTERNATIONAL ORGANIZATION FOR STANDARDIZATION (1998). ISO 13431 Geotextile and geotestile related products - Determination of tensile creep and creep rupture behaviour. Switzerland.

KAMIJI, T. S. M. M. (2006). Fluência de geotêxteis não tecidos através de ensaios confinados. Dissertação (Mestrado em Geotecnia) - Departamento de Geotecnia, Escola de Engenharia de São Carlos, Universidade de São Paulo, São Carlos, 148 p.

KAZIMIEROWICZ-FRANKOWSKA, K. (2005). Correlation between the results of creep 
and relaxation tests of geotextiles. Geosynthetics International, v. 12, n. 5, p. 269-275.

KOERNER, R. M. (2005). Designing with geosynthetics. $5^{\circ}$ ed. Upper Sadle River: PrenticeHall, 796 p.

KOERNER, R. M.; LORD JR., A. E.; HSUAN, Y. H. (1992). Arrhenius modeling to predict geosynthetic degradation. Geotextiles and Geomembranes, v. 11, n. 2, p. 151-183.

MATICHARD, Y.; LECLERCQ, B.; SEGOUIN, M. (1990). Creep of geotextiles: soil reinforcement applications. In: Geotextiles, Geomembranes and Related Products, 4th, The Hague, 1990. Proceedings. Rotterdam, Balkema. v.2, p. 661-665.

MCGOWN, A.; ANDRAWES, K. Z.; KABIR, M. H. (1982). Load-extension testing of geotextiles confined in soil. In: INTERNATIONAL CONFERENCE ON GEOSYNTHETICS, 2th, 1982, Las Vegas, Proceedings. Las Vegas: International Geosynthetic Society, 1982. p. 793-798.

MÜLLER-ROCHHOLZ, J. (1998). Practicalities of measurement of creep and stress rupture. In: Creep and Assessment of Geosynthetics for Soil Reinforcement, Leatherhead, 1997. Proceedings, Leatherhead, p. 1.1-1.12.

PERKINS, S. W. (2000). Constitutive modeling of geosynthetics. Geotextiles and Geomembranes, v. 18, n. 5, p. 273-292.

RIMOLDI, P.; MONTANELLI, F. (1993). Creep and accelerated creep testing for geogrids. In: GEOSYNTHETICS '93, Vancouver, Proceedings. Vancouver: International Geosynthetic Society, 1993. p. 773-787.

SAWICKI, A.; KAZIMIEROWICZ-FRANKOWSKA, K. (1998). Creep behavior of geosynthetics. Geotextiles and Geomembranes, v. 16, n. 6, p. 365-382.

SAYÃO, A.; AZAMBUJA, E.; EHRLICH, M.; GOMES, R. C. (2004). Aplicação em Reforço de Solos - Muros e Taludes Reforçados. In: VERTEMATTI, J. C. Manual brasileiro de geossintéticos. São Paulo: Edgard Blücher. Cap. 4, p. 84-123.

SCAFFARO, R.; DINTCHEVA, N. T.; LA MANTIA, F. P. (2008). A new equipment to measure the combined effects of humidity, temperature, mechanical stress and UV exposure on the creep behavior of polymers. Polymer Testing, v. 27, n. 1, p. 49-54. 
SEGRESTIN, P.; FREITAG, N. (2006). Opinions about creep rupture in soil reinforcement design. In: INTERNATIONAL CONFERENCE ON GEOSYNTHETICS, 8th, 2006, Yokohama, Proceedings. Yokohama: International Geosynthetic Society, 2006. p. 1595-1598.

SHRESTHA, S. C.; BELL, J. R. (1982). Creep behavior of geotextiles under sustained loads. In: International Conference on Geotextiles, 2nd. Proceedings. Las Vegas, v. 3, p. 769-774.

SIMONINI, P.; GOTTARDI, G. (2003). The viscoplastic behavior of a geogrid-reinforced model wall. Geosynthetics International, v. 10, n. 1, p. 34-46.

THORNTON, J. S.; ALLEN, S. R.; THOMAS, R. W. (1997). Approaches for the prediction of long term viscoelastic properties of geosynthetics from short term tests. In: GEOSYNTHETICS '97, 1997, Atlanta, Proceedings. Atlanta: International Geosynthetic Society, 1997. p. 277-291.

THORNTON, J. S.; ALLEN, S. R.; THOMAS, R. W.; SANDRI, D. (1998). The Stepped Isothermal Method for Time-Temperature Superposition and its Application to Creep Data on Polyester Yarn. In: INTERNATIONAL CONFERENCE ON GEOSYNTHETICS, 6th, 1998, Atlanta, Proceedings. Atlanta: Industrial Fabrics Association, 1998. p. 699-706.

THORNTON, J. S.; BAKER, T. L. (2002). Comparison of SIM and conventional methods for determining creep-rupture behavior of a polypropylene geotextile. In: INTERNATIONAL CONFERENCE ON GEOSYNTHETICS, 7th, 2002, Nice, Proceedings. Nice: International Geosynthetic Society, 2002. p. 1545-1550.

TRENTINI, R. S.; VIDAL, D.; MARTINS, P. M. (2006). Chemical ageing and creep analyses - influence of synergy and test specimen preparation. In: INTERNATIONAL CONFERENCE ON GEOSYNTHETICS, 8th, 2006, Yokohama, Proceedings. Yokohama: International Geosynthetic Society, 2006. p. 1609-1612.

VAN ZANTEN, R. V. (1986). Geotextiles and geomembranes in civil engineering. Rotterdam, Balkema. 658 p.

VERTEMATTI, J. C. (2004). Aplicação em Reforço de Solos - Introdução. In: VERTEMATTI, J. C. Manual brasileiro de geossintéticos. São Paulo: Edgard Blücher. Cap. 4, p. 63-71.

WU, J. T. H. (1991). Measuring inherent load-extension properties of geotextiles for design of reinforced structures. Geotechnical Testing Journal, v. 14, n. 2, p. 157-165. 
ZORNBERG, J. G.; BYLER, B. R.; KNUDSEN, J. W. (2004). Creep of geotextiles using time-temperature superposition methods. Journal of Geotechnical and Geoenvironmental Engineering, v. 130, n. 11, p. 1158-1168. 
- 134 - 